\title{
Krypton-85 Health Risk Assessment for a Nuclear Fuel Reprocessing Plant
}

P. J. Mellinger

L. W. Brackenbush

J. E. Tanner

E. S. Gilbert

August 1984

Prepared for the U.S. Department of Energy under Contract DE-AC06-76RLO 1830

Pacific Northwest Laboratory Operated for the U.S. Department of Energy by Battelle Memorial Institute 


\title{
DISCLAIMER
}

This report was prepared as an account of work sponsored by an agency of the United States Government. Neither the United States Government nor any agency thereof, nor any of their employees, makes any warranty, express or implied, or assumes any legal liability or responsibility for the accuracy, completeness, or usefulness of any information, apparatus, product, or process disclosed, or represents that its use would not infringe privately owned rights. Reference herein to any specific commercial product, process, or service by trade name, trademark, manufacturer, or otherwise, does not necessarily constitute or imply its endorsement, recommendation, or favoring by the United States Government or any agency thereof. The views and opinions of authors expressed herein do not necessarily state or reflect those of the United States Government or any agency thereof.

\author{
PACIFIC NORTHWEST LABORATORY \\ operated by \\ BATTELLE \\ for the \\ UNITED STATES DEPARTMENT OF ENERGY \\ under Contract DE-AC06-76RLO 1830
}

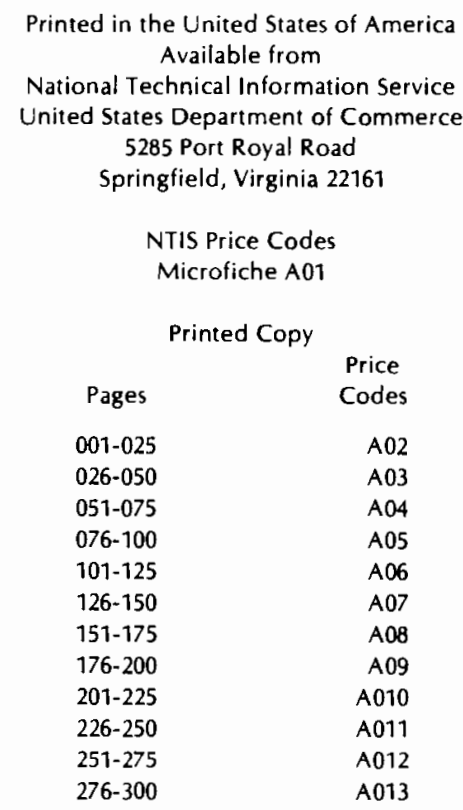


P. J. Mellinger

L. W. Brackenbush

J. E. Tanner

E. S. Gilbert

August 1984

Prepared for

the U.S. Department of Energy under Contract DE-AC06-76RLO 1830

Pacific Northwest Laboratory

Richland, Washington 99352 


\section{ACKNOWLEDGMENTS}

The authors would like to thank al1 those who helped make th is study possible. This work was sponsored by the U.S. Department of Energy, Office of Spent Fue 1 Management and Reprocessing Systems. DOE Technical direction was provided by $H$. E. Stel 1 ing. In particular we thank G. R. Hoenes, E. D. MCClanahan, Jr., and R. G. Schreckhise for their review and constructive criticism, A. Marshall for editing, and L. L. Riley and C. A. Jordon for typing of the manuscript. A special thanks goes to C. F. Schauls for assemb 1 ing the final document. 


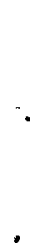




\section{CONTENTS}

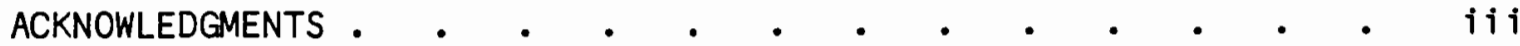

FIGURES •

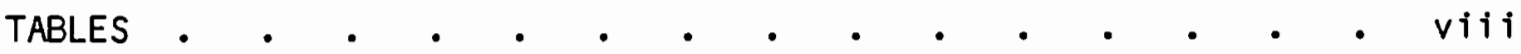

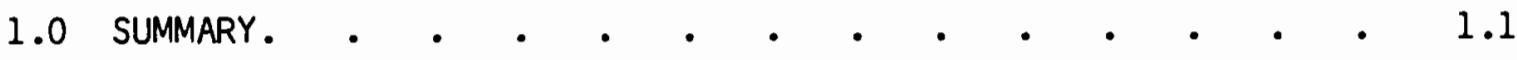

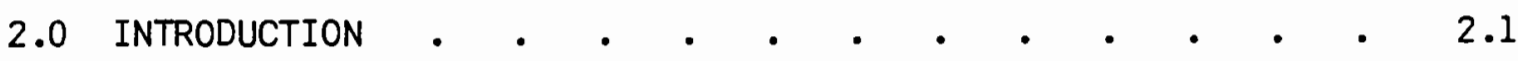

3.0 THE REPRESENTATIVE NUCLEAR FUEL REPROCESSING PLANT • • • 3.1

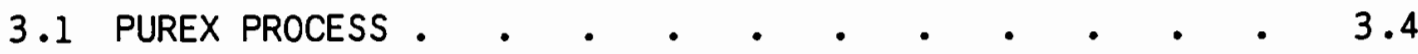

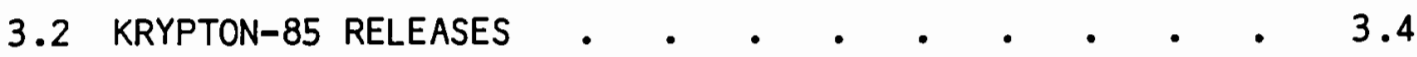

3.3 CRYOGENIC DISTILLATION. • • • • • • • • • • • 3.6

3.3.1 Process and Facilities . . . . . . . 3.6

3.3.2 Shielding and Special Handling . . . . . . 3.11

3.3.3 Operation and Maintenance . . . . . . 3.12

3.3 .4 Personnet • . . . . . . . . . . 3.12

3.4 FLUOROCARBON ABSORPTION • • • • • • • • •

3.4.1 Process and Facilities . . . . . . . 3.13

3.4.2 Shielding and Special Handling • • • • • 3.17

3.4.3 Operation and Maintenance . . . . . . . 3.17

3.4 .4 Personnet • . . . . . . . . . . 3.18

3.5 ION IMPLANTATION/SPUTTERING $\quad . \quad$. $\quad . \quad$ • $\quad 3.18$

3.5.1 Process and Facilities . . . . . . . 3.18

3.5.2 Shielding and Special Handling . . . . . 3.21

3.5 .3 Operation and Maintenance . . . . . . 3.24

3.5 .4 Personnel $. \quad . \quad . \quad . \quad . \quad . \quad . \quad . \quad . \quad 3.25$

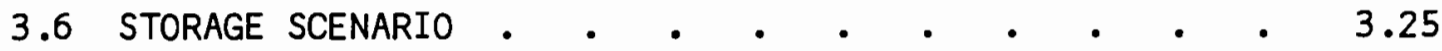

4.0 THE BARNWELL NUCLEAR FUEL PLANT ENVIRONMENT. • • • • • 4.1

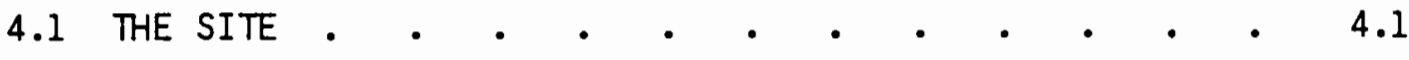

4.2 REGIONAL DEMOGRAPHY $•$ • 
4.3 REGIONAL METEOROLOGY •

5.0 KRYPTON-85 DOSE COMMITMENTS • • • • • • • • • 5.1

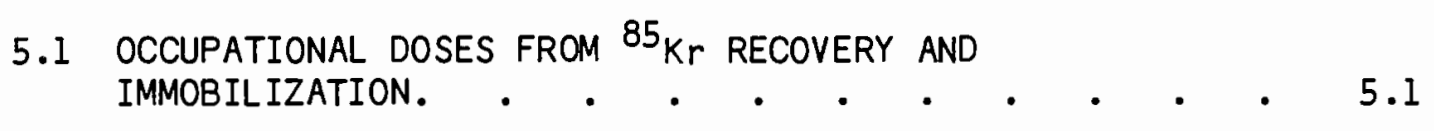

5.1.1 Occupational Doses from Cryogenic Distillation

Facility • • • • • . . • • . 5.1

5.1.2 Occupational Doses from Fluorocarbon Absorption

Facility . . . . . . . . . . 5.5

5.1.3 Occupational Doses from an Ion Implantation/

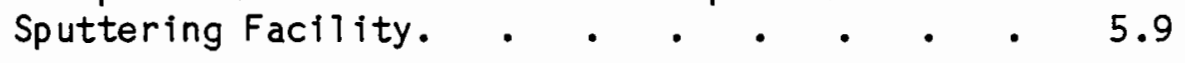

5.1 .4 Summary of Occupational Doses . . . . . 5.13

5.2 PUBLIC EXPOSURE TO $85_{\mathrm{Kr}}$ RELEASED ROUTINELY FROM

THE FRP • • • • • • • • • • • • • 5.15

5.2.1 Maximum Individual Dose. . . . . . . 5.15

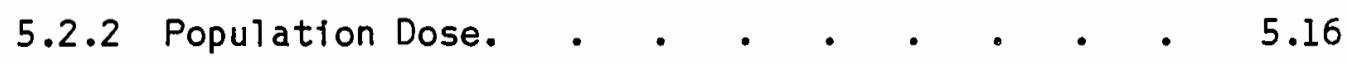

5.2.3 Summary of Estimated Occupational Doses vs.
Public Radiation Doses. . . . . . 5.17

6.0 HUMAN HEALTH EFFECTS • • • • • • • • • • • •

7.0 REFERENCES • • • • • • • • • • • • • • • • • 7.1

APPENDIX A - SOURCE TERM SENSITIVITY ANALYSES. • • • • • • A.I

APPENDIX B - METHODS FOR CALCULATING OCCUPATIONAL DOSES FROM

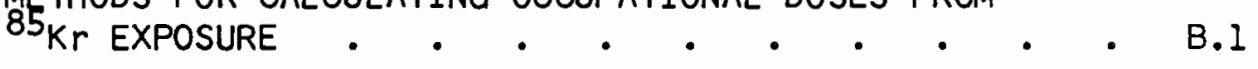

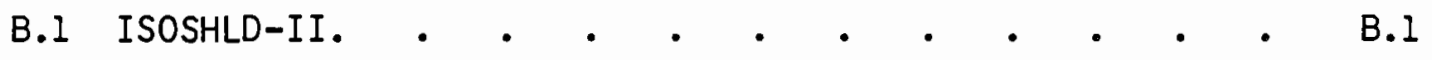

B.2 CYLIN •

APPENDIX C - EQUATIONS FOR CALCULATING DOSES FROM KRYPTON-85 EXPOSURE TO THE PUBLIC $\quad \cdot \quad \cdot \quad \cdot \quad \cdot \quad \cdot \quad \cdot \quad \cdot \quad$ C.I

C.I MAXIMUM INDIVIDUAL DOSE $\cdot \cdot \cdot \cdot \cdot \cdot \cdot \cdot \cdot \cdot \cdot \cdot c .1$

C.2 50-MILE POPULATION DOSE.$\quad \cdot \quad \cdot \quad \cdot \quad \cdot \quad \cdot \quad \cdot \quad \cdot \quad c .2$ 


\section{EIGURES}

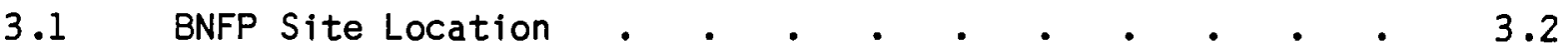

3.2 Plot Plan of the Barnwell Plant . . . . . . . 3.3

3.3 Dissolver Off-Gas Process Building . . . . . . . . 3.8

3.4 Process Flowsheet for the Dissolver Off-gas Krypton Recovery System After the Removal of Oxides of Nitrogen and Carbon Dioxide from the Feed Stream • . . . . . . . 3.9

$3.5 \quad$ Fluorocarbon Absorption Process for Krypton Removal • $\quad 3.14$

3.6 Thermionically Supported Plasma Sputtering/Ion Implantation Components . . . . . . • . . 3.19

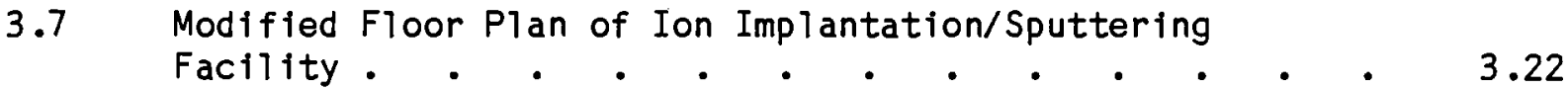

4.1 Lower Three Runs Creek Watershed . • • • • • • . 4.2

4.2 Sector Detail Within First 10 Miles from BNFP Process Area. . . . . . . . . . . . 4.3

4.3 Urban Areas Greater Than 1000 Population Within 50 Miles of the BNFP . . . . . . . . . . . 4.4

5.1 Calculated Dose Equivalent Rates Inside the Cryogenic Distillation Krypton Recovery Facility . • . . . 5.3

5.2 Dose Rates in Fluorocarbon Absorption Cell Near Various Pieces of Equipment . . . . . . . . . . 5.6

5.3 Locations Where Dose Equivalent Rates are Calculated for Ion Implantation/Sputtering Facility . . . . 5.10

A.1 Spent Fuel in Storage with Three Reprocessing Scenarios . A.9 


\section{TABLES}

3.1 Material Balance for the Krypton Recovery System . . . 3.10

3.2 Staffing Requirements for the Cryogenic

Distillation System . . . . . . . . . . 3.13

Material Balance Flowsheet for Krypton Removal by
Fluorocarbon Absorption . . . . . . . . . . . 3.16

3.4 Fraction of $85 \mathrm{Kr}$ Released in 100 Years . . . . . . $\quad 3.20$

3.5 Operating and Support Areas and Shielding Specifications - 3.23

3.6 Staffing Requirements for the Ion Implantation/Sputtering 3.25

4.1 2005 Population Distribution Estimates Within 50 Miles of the BNFP • . . . . . . . • . . . 4.6

4.2 Annual Average Atmospheric Dispersion Factors for the BNFP Separations Facility Main Stack . . . . . . 4.7

5.1 Maintenance Requirements for Cryogenic Distillation

Facility • . . . . . . . . . . . 5.4

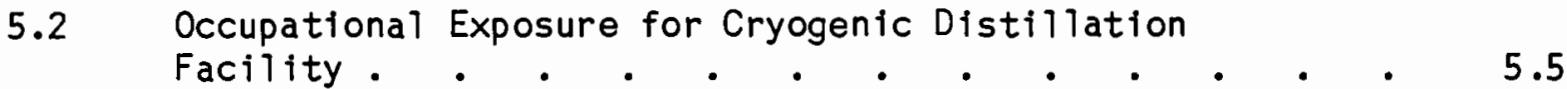

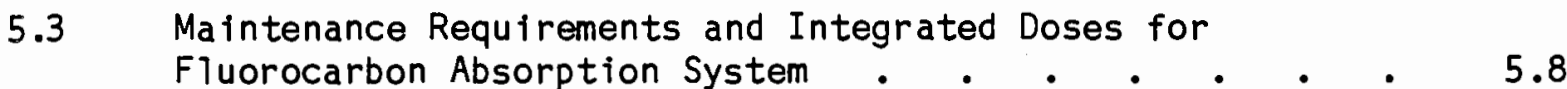

5.4 Calculated Dose Equivalent Rates at Various Locations

Inside the Ion Implantation/Sputtering Facility . . . 5.11

5.5 Operational Doses from Handling and Processing ${ }^{85} \mathrm{Kr}$ in the Ion Implantation/Sputtering Facility . . . . 5.12

5.6 Maintenance Requirements and Occupational Doses from Equipment in Radiation Zones in the Ion Implantation/ Sputtering Facility . . . . • • • • • • 5.14

5.7 Summary of Operational and Contact Maintenance Doses for Each Year of Operation of $85 \mathrm{Kr}$ Separation and Encapsulation Facilities • • • • • • • •

5.8 Comparison of Radiation Dose Rates from Two Krypton Removal Technologies with Ion Implantation Versus Public Exposure from Routine Release to the Environment . . . 5.17

6.1 Comparison of Estimated Cancer Mortality from the Capture and Immobilization of $85_{\mathrm{Kr}}$ as Opposed to Routine Release to the Environment 
TABLES (continued)

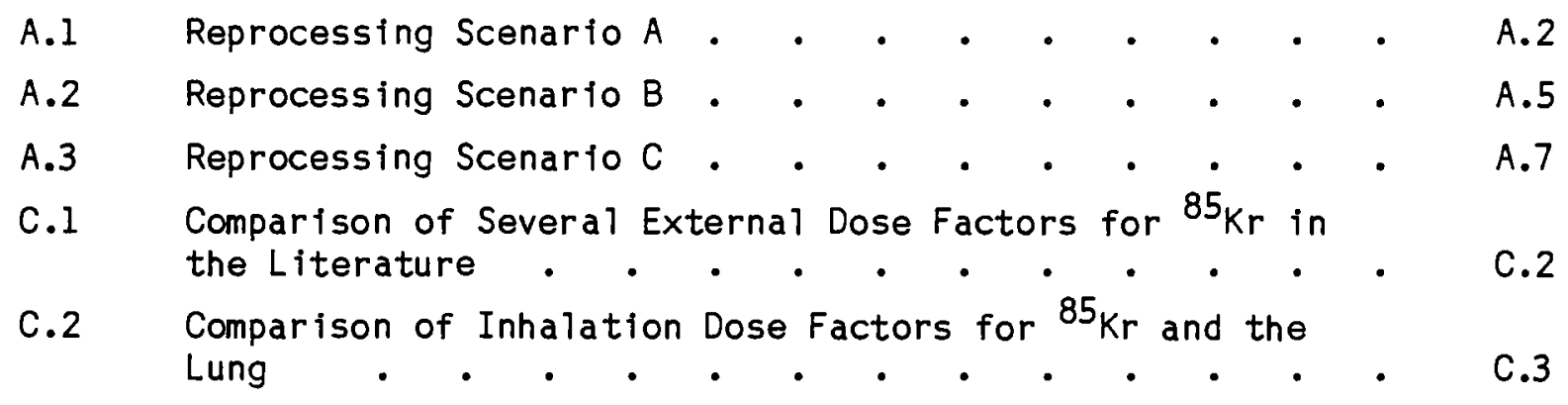




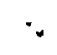




\subsection{SUMMARY}

In order to investigate the impact of the Environmental Protection Agency's regulations in the Final Environmental Statement - 40 CFR $190=$ Environmental Protection Requirements for Normal Operation of Activities in the Uranium Fuel Cycle (EPA 1976b), a health risk assessment was done at Pacific Northwest Laboratory for the Department of Energy to investigate the comparative risks invol ved in the routine release of $85_{\mathrm{Kr}}$ from nuclear fuel reprocessing operations to the environment were compared to those resulting from the capture and storage of ${ }^{85} \mathrm{Kr}$.

Krypton-85 is one of the fission products in fuel elements that are normally released when fuel is reprocessed. Instead of releasing the $85_{\mathrm{Kr}}$ to the environment, it can be captured, immobilized and stored. Two alternative methods of capturing ${ }^{85} \mathrm{Kr}$, cryogenic distillation and fluorocarbon absorption, and one method of immobilizing the captured gas, ion implantation/sputtering, were theoretically incorporated into a representative fuel reprocessing plant, the Barnwel 1 Nuclear Fuel Plant (BNFP), for this study, even though there are no known plans to start up this facility.

For this study we treat the occupational workforce the same as general pub 1 ic and therefore compare their radiation doses accordingly. Workforce and population radiation doses were calculated and analyzed for operating and maintaining the two capture options for immobilization. Those doses were then compared to the public doses from routine release of $85 \mathrm{Kr}$.

The average occupationa $11 y$ exposed worker was estimated to receive about 400 to $600 \mathrm{mrem} / \mathrm{yr}$ ( 3 to 4 man-rem $\mathrm{yr}$ ) from ${ }^{85} \mathrm{Kr}$ recovery and immobiization activities. This dose is a factor of 20,000 to 30,000 higher than the estimated dose to the maximum offsite individual $(0.02 \mathrm{mrem} / \mathrm{yr})$, and a factor of 130,000 to 200,000 higher than the dose received by the average member of the 50-mile population $(0.003 \mathrm{mrem} / \mathrm{yr}$ or $2.4 \mathrm{man}-\mathrm{rem} / \mathrm{yr})$ from routine release of al $185 \mathrm{Kr}$.

A National Academy of Sciences report (NAS 1980), referred to here as BEIR III, discussed several models for estimating 1 ifetime health risks. We chose to use the 1 inear-quadratic relative risk model because we bel ieve 
it is the most realistic. Unfortunately, no adequate health risk data exist for comparing health effects for exposure rates of approximately $500 \mathrm{mrem} /$ year and exposure rates of approximately $0.003 \mathrm{mrem} /$ year, the situations of interest here.

Given the uncertainties in the models used to generate 1 ifetime risk numbers (0.02-0.027 radiation induced fatal cancers expected in the eccupational workforce and 0.017 fatal cancers in the general population), the differences in total risks for the three situations, (i.e., no-capture and two-capture alternatives) cannot be considered meaningful. It is possible that no risks would occur from any of the three situations. There is certainly no reason to conclude that risks from ${ }^{85} \mathrm{Kr}$ routinely released to the environment are greater than those that would result from the other two situations considered.

Present regulations mandate recovery and disposal of ${ }^{85} \mathrm{Kr}$ from the off gases of a facility reprocessing spent fuel from commercial sources. Because of the 1 ack of a clear-cut indication that recovery would be beneficial, it does not seem prudent to burden the facilities with a requirement for ${ }^{85} \mathrm{Kr}$ recovery, at least until operating experience demonstrates the incentive. The probable high aging of the early fuel to be processed and the higher dose resulting from the release of the unregulated ${ }^{3} \mathrm{H}$ and ${ }^{14} \mathrm{C}$ (Exxon Nuclear Co. 1977) also encourage delaying implementation of the ${ }^{85} \mathrm{Kr}$ recovery in the early plants.

This document provides useful data that will be used in a companion document that reviews EPA calculational methodology embodied with in 40 CFR 190 requiring $85 \mathrm{Kr}$ recovery for FRPs. 


\subsection{INTRODUCIION}

In the early 1970's, rapid growth of the nuclear power industry was predicted. The Environmental Protection Agency (EPA) projected that there would be 1000 GWe of installed nuclear capacity by the year 2000 (EPA 1973). In order to minimize public exposure to radiation from the operation of the nuclear fuel cycle, the EPA issued a "Draft Environmental Statement for a Proposed Rulemaking Action concerning the Environmental Radiation Protection Requirements for Normal Operations of Activities in the Uranium Fuel Cycle," (EPA 1975). This document was fol lowed on January 5, 1976, by "Environmental Radiation Protection for Nuclear Power Operations - Proposed Standards (40 CFR 190) Supplementary Information" (EPA 1976a). These documents received extensive external review, and numerous substantive comments were submitted to the Agency. On November 1, 1976, the EPA issued the Final Environmental Statement - 40 CFR 190 - Environmental Radiation Protection Requirements for Normal Operations of Activities in the Uranium Fuel Cycle in two volumes (EPA 1976b). The provisions of 40 CFR 190 apply to radiation doses received by members of the general public and to releases of selected radionuclides that result from operations of the nuclear fuel cycle.

One of the radionuclides specified in 40 CFR 190 is $85 \mathrm{Kr}$, which is a fission product in fuel elements irradiated in nuclear power plants. Because almost all of the ${ }^{85} \mathrm{Kr}$ remains in spent fuel elements until it decays or until the fuel elements are reprocessed, nearly all the ${ }^{85} \mathrm{Kr}$ released from the nuclear fuel cycle has come from fuel reprocessing $p l a n t s$ (FRPs).

The purpose of FRPs is to chemical ly separate and recover uranium and plutonium from spent commercial power reactor fuel. In the first stage of reprocessing, certain components in the spent fuel are dissolved in hot nitric acid. During this acid dissolution stage, ${ }^{85} \mathrm{Kr}$ is released to the dissolver off-gas (DOG) system. Historically, the krypton contained in the DOG has been routinely released to the environment from fuel reprocessing operations. 
The EPA's regulations 1 imit radiation doses to any member of the public to $25 \mathrm{mrem} / \mathrm{yr}$ to the whole body and to any organ except the thyroid $\mathrm{gland}$, which is $1 \mathrm{imited}$ to $75 \mathrm{mrem} / \mathrm{yr}$, from normal routine releases from a fuel cycle site (EPA $1976 \mathrm{~b}$ ). These regulations also 1 imit the ${ }^{85} \mathrm{Kr}$ release to $50,000 \mathrm{Ci} / \mathrm{GWe}-y \mathrm{r}$ of electrical energy produced from fue 1 irradiated after January 1, 1983. In order to comply with these regulations, alternatives to normal release of ${ }^{85} \mathrm{Kr}$ have been developed. Instead of releasing the DOG to the environment, the radionuclide-containing gas can be treated where the ${ }^{85} \mathrm{Kr}$ is captured, concentrated, immobilized, and stored for long periods of time. A health risk assessment was therefore done at Pacific Northwest Laboratory (PNL) for the U.S. Department of Energy (DOE) in order to compare the potential risks to the public from routine release of $85_{\mathrm{Kr}}$ with the risks to the workforce from capture and immobilization of $85_{\mathrm{Kr}}$ at a reference FRP. We proceeded with the assumption that at microrem/yr doses individual population segment radiosensitivities are lost in the uncertainties of the analysis. Therefore, individuals in the workforce can be compared to members of the general public because, as humans, they have essentially the same risks of dying of cancer from radiation exposure.

In the early 1970's when 40 CFR 190 was issued, the existing Nuclear Fuel Services FRP, located at West Valley, New York, had shut down for a planned facility expansion. The Barnwel 1 Nuclear Fuel Plant, Barnwel1, South Carolina, and the Midwest Fuel Recovery Plant, Morris, I1 1 inois were under construction, and Exxon Nuclear had announced plans to construct a 2000-t/yr plant in eastern Tennessee. The predicted growth in the nuclear industry has not occurred, and, in fact, projections are stil1 being revised downward; in the three years from 1980 to 1982 (DOE 1981, 1982, 1983), projections for the year 2000 have dropped from 180 GWe (in 1980) to $165 \mathrm{GWe}$ (in 1981) to $130 \mathrm{GWe}$ (in 1982). Now it is 1 ikely that instead of the predicted 18 FRPs operating by the year 2000 (EPA 1973), there could be none. Because there are no FRPs in operation, spent fuel is being stored instead of reprocessed; the longer spent fuel is stored before it is reprocessed, the less ${ }^{85} \mathrm{Kr}$ would be released during reprocessing because of natural radioactive decay. The need to capture and store $85_{\mathrm{Kr}}$ should be 
reviewed in regard to the actual number of operating FRPs that wi 11 contribute to exposing the public to radiation from the nuclear fuel cycle.

For this study, the Barnwel 1 Nuclear Fuel Plant (BNFP) was chosen as a representative FRP because it most closely resembles an operating FRP. The BNFP has been constructed and cold tested but has never been operated. Two alternative methods of capturing ${ }^{85} \mathrm{Kr}$ (cryogenic distillation and fiuorocarbon absorption) and one method of immobilizing the captured radionuclide (ion implantation/sputtering) were theoretically incorporated into the representative BNFP. The increased radiation dose commitment to the operation and maintenance workforce at the reference FRP due to capturing and immobilizing the ${ }^{85} \mathrm{Kr}$ was compared to the public radiation dose commitment that would result from the routine release of all the ${ }^{85} \mathrm{Kr}$ to the atmosphere. This document provides useful data that wil1 be used in a companion document that reviews EPA calculational methodology embodied with in 40 CFR 190. 

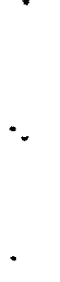


\subsection{THE REPRESENTATIVE NUCLEAR FUEL REPROCESSING PLANT}

In 1968, A 11 ied-Genera 1 Nuclear Services (AGNS) was formed by A11 ied Chemical and Gulf $0 i 1$ to construct and operate the Barnwe 11 Nuclear Fuel Plant (BNFP) to chemically process spent nuclear fuel. The BNFP construction permit was granted by the Atomic Energy Commission (AEC) in 1970 and construction began in 1971. The BNFP is located on the eastern edge of the Department of Energy's (DOE) Savannah River Plant and seven and one-half miles west of the town of Barnwe11, South Carol ina (Figure 3.1). Major facilities of the BNFP are shown in Figure 3.2. Additional detail can be found in the BNFP Environmental Report (AGNS 1971).

The purpose of the BNFP is to chemically separate and recover uranium and plutonium from spent commercial power reactor fuel. The plant was scheduled for startup in early 1974 at a nominal 5-t/day ( $1500 \mathrm{tU} / \mathrm{yr}$ ) throughput. The BNFP incorporated a chop-leach head-end, and used a 3-cycle PUREX sol vent extraction system with pulsed column and centrifugal contactors. Both contact and remote maintenance were designed into this plant. The BNFP has been cold tested using uranium, but has not processed any radioactive spent fue1. During cold testing, some desirable minor modifications were identified and some modifications were made. For various reasons, the owner/operator has elected to terminate further activities at the facility. The technical staff departed in August of 1983 and a reduced maintenance staff stayed on unti 1 November 1983.

Historical1y, the krypton contained in the dissolver off gas has been routinely released to the environment from fue 1 reprocessing operations. There is an alternative to routine release of all the ${ }^{85} \mathrm{Kr}$ and that is to capture, concentrate, and store the gas for long periods of time. Several sets of alternative methods to recover and store the radioactive gas were considered by Mellinger et a1. (1980) for a generic FRP. This effort is being refined here by theoretically placing a cryogenic distillation or a fluorocarbon absorption system and an ion implantation/sputtering facility at the BNFP site. A defined population distribution and meteorological data are used from the BNFP site environment (Chapter 4). 


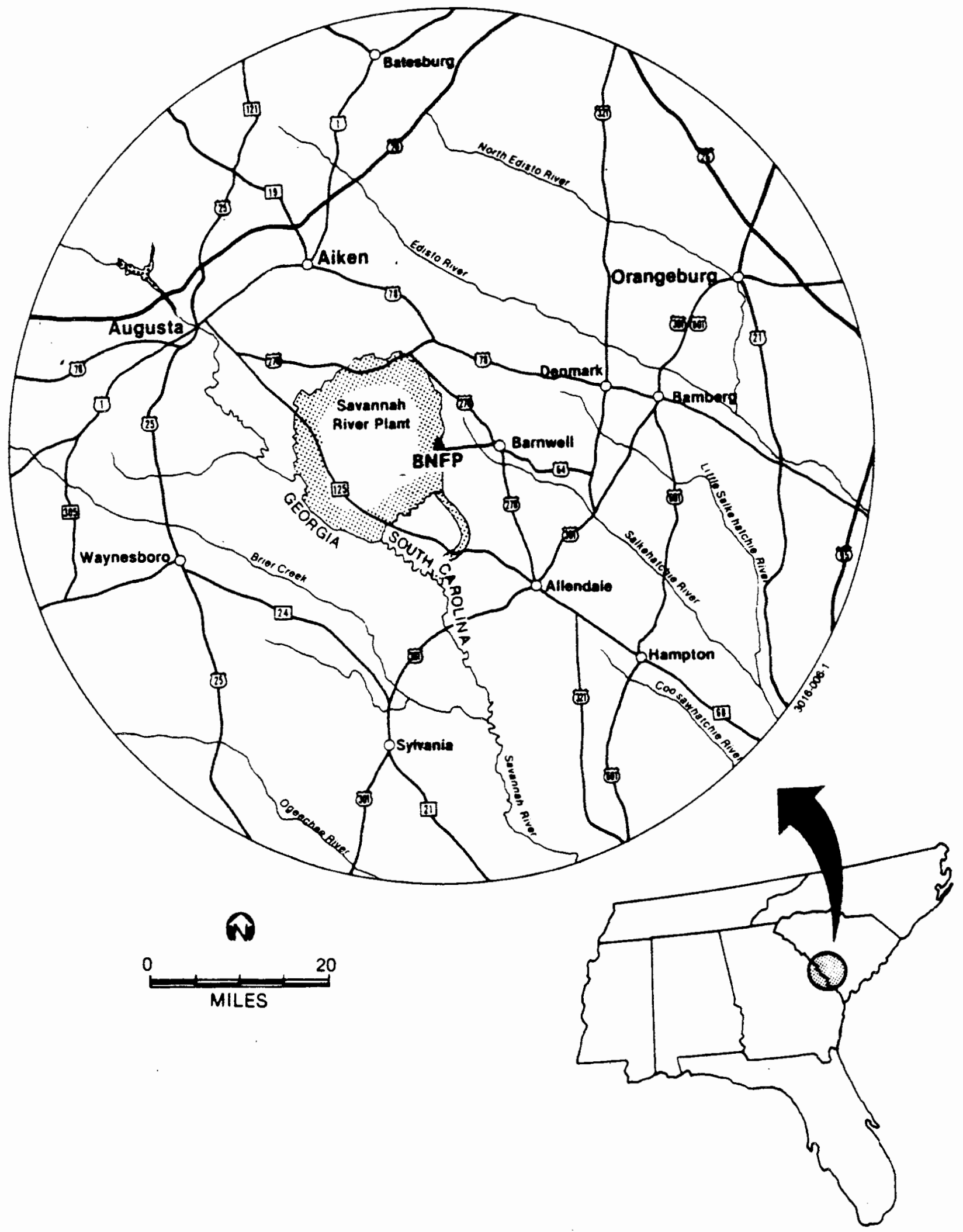

FIGURE 3.1. BNFP Site Location 


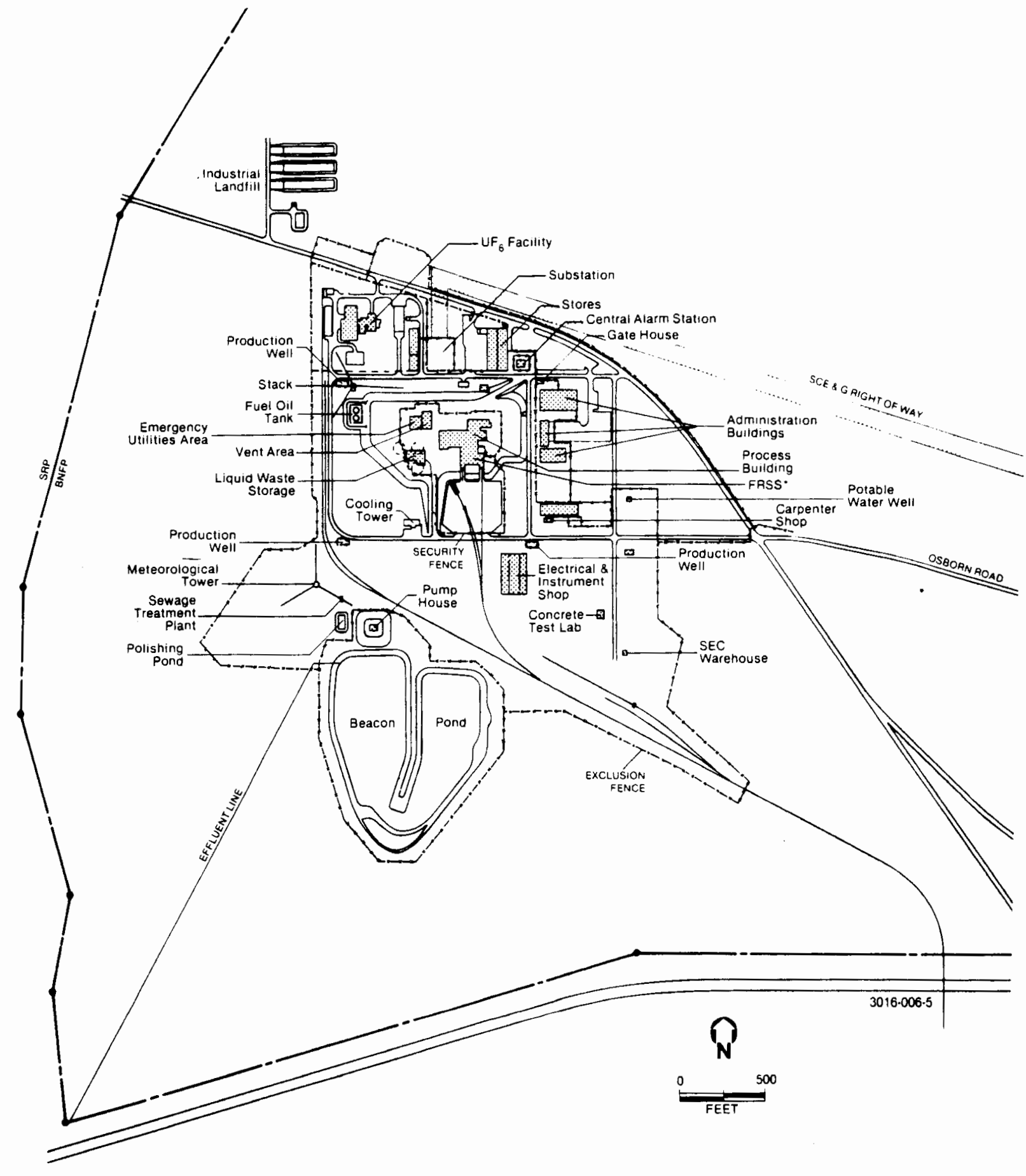

FIGURE 3.2. Plot Plan of the Barnwell Plant (AGNS 1981) 
This health risk assessment is being carried out as if the BNFP were in ful 1 operation and employed a noble gas recovery, immobilization, and storage system. The fol lowing are brief descriptions of the PUREX process, whose head-end and dissolver release the ${ }^{85} \mathrm{Kr}$ from the fuel; the cryogenic distillation system and the alternative fluorocarbon absorption system that concentrate the ${ }^{85} \mathrm{Kr}$; the ion implantation/sputtering process that immobi1 izes the captured gas; and the storage scenario.

\subsection{PUREX PROCESS}

The BNFP is designed to use a solvent extraction process to recover $1500 \mathrm{t} / \mathrm{yr}$ of uranium. A chop-leach head-end prepares fuel for dissolution in hot nitric acid. The uranium and plutonium in the solution are then separated and purified in three solvent extraction cycles. The separation process currently used commercial $1 y$ is the aqueous 1 iquid-1 iquid sol vent extraction (PUREX) process developed for military purposes. The PUREX process converts the materials of interest into aqueous solutions by acid dissolution (primarily $\mathrm{HNO}_{3}$ ). During acid dissolution, the ${ }^{85} \mathrm{Kr}$ is released to the dissolver off-gas system (DOG). The first cycle separates uranium and plutonium from fission products (general1y $30 \%$ tributy 1 phosphate (TBP) in a kerosene-type diluent). The heart of the PUREX process consists of two separate solvent extraction cycles, where the separated uranium and plutonium streams are decontaminated and further purified and concentrated.

\subsection{KRYPTON-85 RELEASES}

Krypton-85 is formed as a fission product in fuel elements of nuclear power plants. The vast majority of the krypton is retained in the fuel element and would on $1 y$ be released if the fuel was reprocessed. Based on calculations using the computer code ORIGEN (Bel1 1973), the quantities of fission products present in recently discharged spent nuclear fuel have been previous $7 y$ reported (ORNL 1970; Exxon Nuclear 1977; and Brown, Knecht and Thomas 1978). For $85 \mathrm{Kr}$, this value ranges from 8,500 to $11,200 \mathrm{Ci} / \mathrm{tHM}$ (curies/metric ton of heavy meta1) in the fuel. For fuel irradiated at a specific power of $30 \mathrm{MW} / \mathrm{tHM}$ with a total burnup of $33,000 \mathrm{MWd} / \mathrm{tHM}$, the 
calculated ${ }^{85} \mathrm{Kr}$ content 160 days after discharge of the fuel from the reactor is about $10,500 \mathrm{Ci} / \mathrm{tHM}$. A smal1 percentage of fuel elements develop minute leaks in the fuel cladding during irradiation and hand 1 ing, releasing $<1 \%$ of the noble gases to the reactor off-gas system. Therefore, the routine releases of $85 \mathrm{Kr}$ from commercial LWRs are insignificant when compared to the potential releases from fuel reprocessing operations. It is shown in Chapter 5 that FRP releases can also be insignificant.

As of 1983, the U.S. had accumulated about $9000 t$ of spent nuclear fuel ranging in age from "fresh" to more than 12 years $01 d$. It is unrealistic to assume that, when the U.S. designs, constructs, and 1 icenses a commercial fuel reprocessing plant, "fresh" fuel will be reprocessed when such a tremendous back log of aged fuel exists. A sensitivity analysis on $85 \mathrm{Kr}$ content of aged fuel under three reprocessing scenarios is presented in Appendix $A$. The decay algorithm (used in Appendix $A$ ) requires as input a decay time that is determined by subtracting the year that the spent fue 1 was produced from the year that the spent fuel is expected to be reprocessed. The decay algorithm uses only one decay time for each year of reprocessing and not for each year the fuel was produced, even though several years worth of fuel production may be reprocessed in the same year. If more than one year's production of spent fuel is reprocessed in one year, then the decay time of the newest spent fuel is used by the decay algorithm. This is conservative, since some of the fuel reprocessed under this scenario has a longer decay time and, therefore, less radioactivity. Under this scenario, the decay algorithm actually over-predicts the ${ }^{85} \mathrm{Kr}$ inventory.

The earliest realistic date that a commercial FRP could become operational would be about the year 2000. At that time, if the oldest fuel is reprocessed first, the facility will never reprocess fuel aged less than about 30 years. Therefore, the routine annual unperturbed release for a 1500-t/yr FRP reprocessing aged fuel is conservatively estimated to be about $3 \times 10^{6} \mathrm{Cr}{ }^{85} \mathrm{Kr}$. This is different than the EPA basis for $40 \mathrm{CFR} 190$ which assumed 160 -day-cooled fuel or about $17 \times 10^{6} \mathrm{Ci}{ }^{85} \mathrm{Kr}$. 


\subsection{CRYOGENIC DISTILLATION}

Cryogenic distillation provides an effective, continuous, smal1-size system for separating krypton and xenon from DOGs by utilizing different boiling points of the main components. It is expected to exhibit a decontamination factor ( $d F$ ) of at least 1000 (EPA 1976c). However, overal 1 efficiency for removal of krypton from the plant is expected to be lower because of potential leakage through the system during maintenance, startup, and shutdown operations. Therefore, an effective plant dF of between 10 and 100 (release fraction of 0.1 to 0.01 ) has been projected for routine operation of a cryogenic distillation system (EPA 1977). One vendor warrants its product for a krypton $d F$ of 10,000 (Airco 1976). A demonstration system on the scale of a commercial facility is required to establish the practical 1 imits for ${ }^{85} \mathrm{Kr}$ recovery from commercial fuel reprocessing facilities.

Cryogenic distillation has been done for research and industrial application at the Idaho Chemical Processing Plant (ICPP) since 1958 (Bendixsen and Offutt 1969). Although the ICPP unit was not designed to achieve the high ${ }^{85} \mathrm{Kr}$ recovery efficiencies necessary for environmental control under current 1 aw (EPA 1976b), its operation has indicated such potential.

Additional experience will be gained from the recent addition of a cryogenic distillation system to a foreign pilot scale FRP. An Airco Cryoplants, Inc., cryogenic distillation process design was incorporated by Kobe Steel into the Tokai-Mura pilot scale reprocessing plant in Japan. The system completed cold testing in 1983, but has not yet undergone hot testing.

\subsubsection{Process and Facilities}

The cryogenic distillation rare gas recovery system is assumed to be an integral part of the 1500-t/yr BNFP. The two facilities share utilities, laboratories, health physics support, operating personnel, change areas, maintenance areas, warehousing, shops, and offices. The off-gas treatment system has sufficient capacity to handle the total stream from 
the reprocessing plant. A theoretical floor plan of a facility developed at Idaho National Engineering Laboratory is used in this assessment and is given in Figure 33. Al 1 normal krypton process operations are handled in the hot cell (located in the upper right-hand corner of the figure). Workers do not normal $1 \mathrm{y}$ come in contact with ${ }^{85} \mathrm{Kr}$.

The reference process design of the treatment facility, shown in Figure 3.4, is a modification of that described in detail by Brown, Knecht and Thomas (1978) and DOE (1979b), and is briefly summarized here. The function of al 1 the equipment outside the cold box is to pretreat the gas stream prior to cryogenic separation. The pretreatment removal of hazardous or troublesome components, such as nitrogen oxide (solidifies $\mathrm{NO}_{2}$ ), oxygen (forms radiolytic ozone), and nitrous oxide (causes excessive freezing), is necessary to create a safe worker environment. The purified process gas then enters a heavily insulated and shielded self-contained structure, commonly called a cold box. The cryogenic unit includes a precooler, an absorption-stripping column, and a fractionation stil1, al1 shown within the cold box in Figure 3.4. Krypton and xenon are condensed in liquid nitrogen in the adsorption column. The liquid is transferred to the fractionation still, and the nitrogen, krypton, and xenon are separated by fractional distillation. The product that boils off is a mixture of $75 \%$ $\mathrm{Kr}$ and $25 \% \mathrm{Xe}$. The design is for $90 \%$ recovery of the ${ }^{85} \mathrm{Kr}$ inventory. We have assumed 95\% recovery for this analysis. The materials balance for the modified overal 1 krypton recovery system materials balance is present in Tab te 3.1 .

A 11 volatile fission products other than $85_{\mathrm{Kr}}$ have been removed from the gas before it reaches the rare gas plant. However, ${ }^{85} \mathrm{Kr}$ is present in the gas in large enough quantities to present a radioactive hazard throughout the entire plant. Therefore, the design of the new facilities must take this into account.

Radioactivity of some process streams rises rapidly in the cold box, and the final krypton gaseous product available for ion implantation/ sputtering from 30-year decayed fuel will be in excess of $33 \mathrm{Ci} / \mathrm{L}$ at $2.7 \mathrm{~atm}$. 


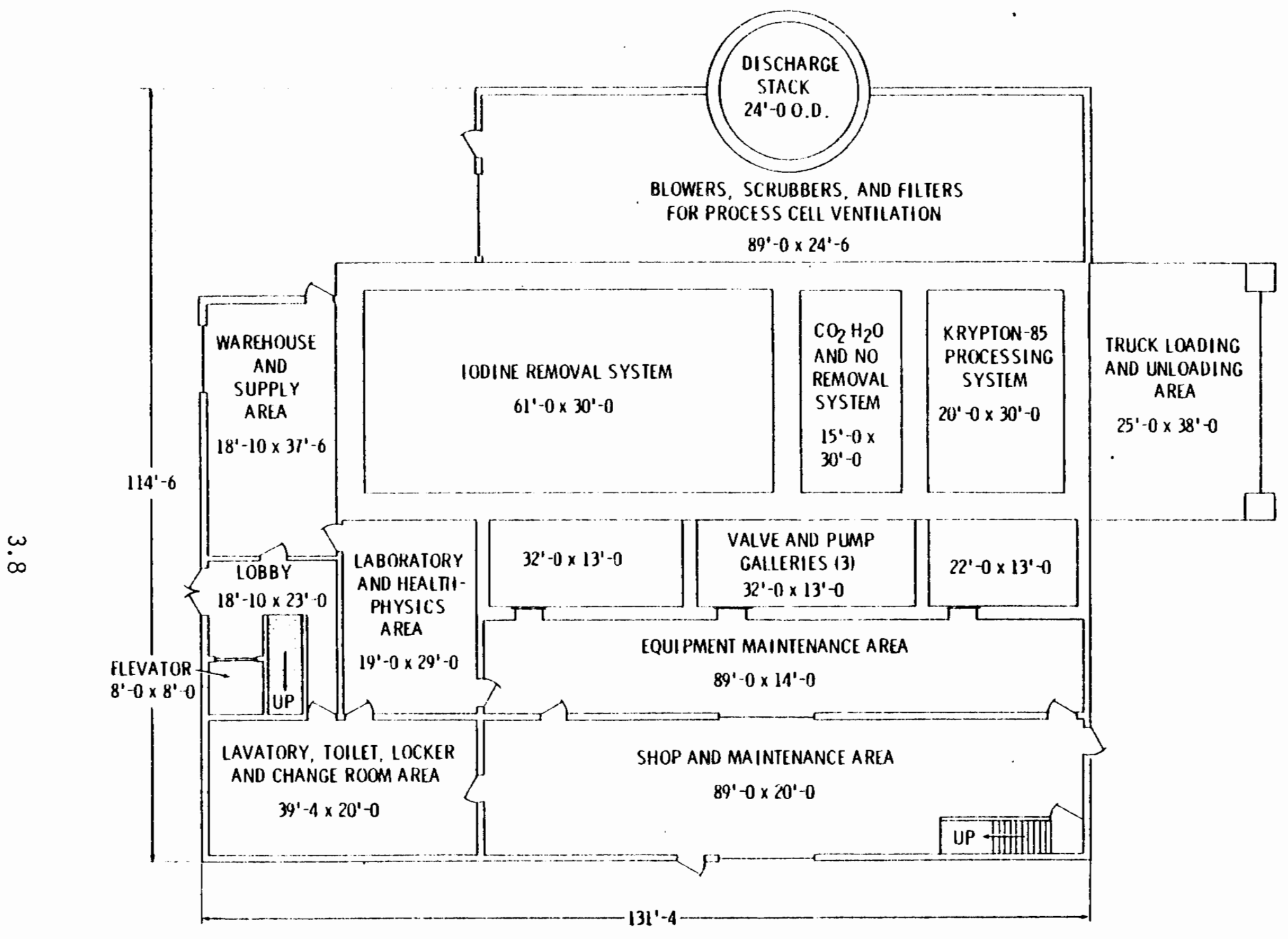

FLOOR PLAN $-[1.0$

FIGURE 3.3. Dissolver Off-Gas Process Building 


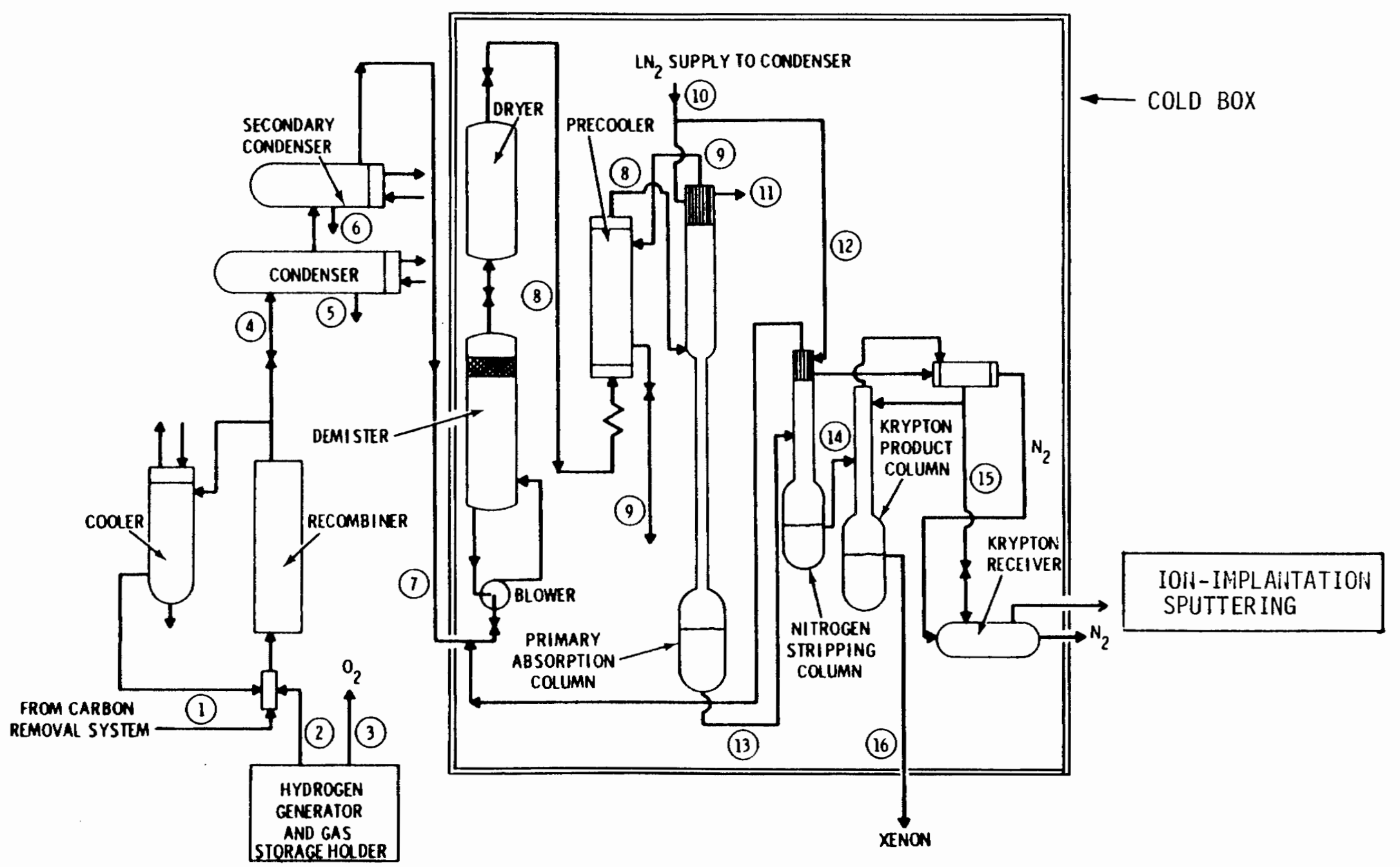

FIGURE 3.4. Process Flowsheet for the Dissolver Off-gas Krypton Recovery System After the Removal of Oxides of Nitrogen and Carbon Dioxide from the Feed Stream (Small circled numbers refer to stream numbers given in Table 3.1) 
TABLE 3.1. Material Balance for the Krypton Recovery System (DOE 1979b)

(Stream numbers refer to circled numbers in Figure 3.4.)

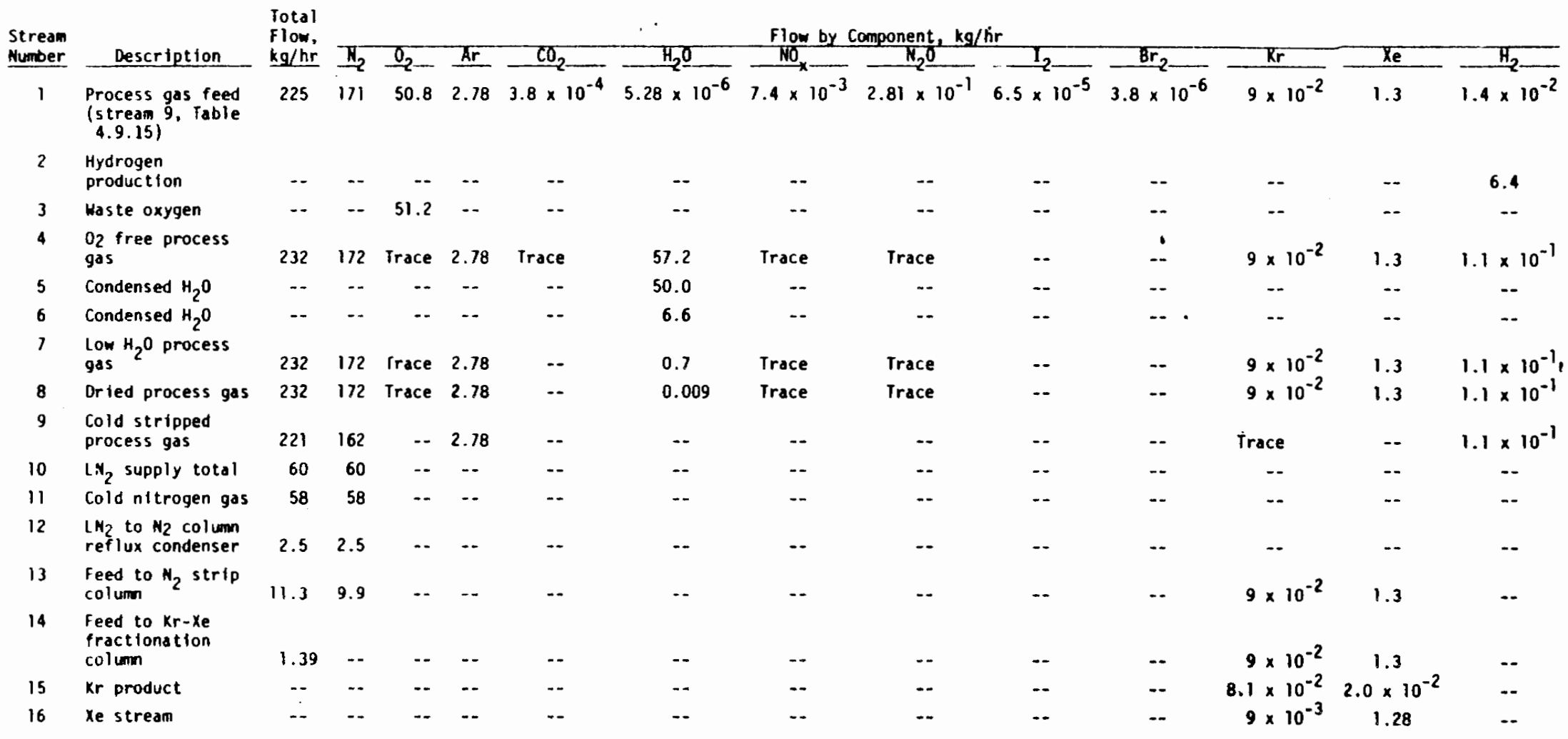




\subsubsection{Shielding and Special Handling}

There are several operations with in the facility which require special treatment to protect workers from potential hazards. Concrete shielding is general ly used in structural walls and lead shielding used where concrete thicknesses for comparable shielding value become cumbersome.

The process gas being treated has an activity of about $2 \mathrm{Ci} / \mathrm{m}^{3(a)}$ before ${ }^{85} \mathrm{Kr}$ is separated from it in the precooler and cryogenic section of the plant. The cryogenic distillation hardware can be adequately shielded by 15-cm concrete wal1s, except for the cold box and the hot cel1, which would require about $76 \mathrm{~cm}$ of concrete. Limited personnel access to such equipment is possible.

This 1 iquid product contains about $4 \mathrm{Ci} / \mathrm{g}$ of ${ }^{85} \mathrm{Kr}$. One day's production, if stored in a receiver, represents a source of about $7 \mathrm{kCi}$ in a volume of $0.78 \mathrm{~L}$ of 1 iquid. This 1 iquid can be stored in dewars for several days without significant loss. If it is desired to hold up the krypton within the cryogenic distillation facility, it can be stored as 1 iquid which can be stored in dewars for several days without significant loss. This source requires a shielding of less than $5 \mathrm{~cm}$ of lead inside the cold box shield. The overall cold box krypton inventory (exclusive of the above-mentioned) is estimated to be 7-ll kCi, located almost entirely in the column reboilers and final product column. Shielding of these sources requires less than $10 \mathrm{~cm}$ of lead or its equivalent. When the krypton receiver is warmed to approximately $-84^{\circ} \mathrm{C}$, the krypton will gasify and flow through shielded transport 1 ines to the ion implantation/sputter facility.

Relative concrete wall thicknesses for the cryogenic facility are shown in Figure $3.3^{\circ}$ (Brown, Knecht and Thomas 1.978).

(a) This value is a ratio of fuel burnup from ORNL-445I (ORNL 1970) and ICP-1126 (Brown, Knecht and Thomas 1978) and adjusted by mu tiplying by 0.144 for 30-year decayed fue 1 . 


\subsubsection{Qperation and Maintenance}

This cryogenic distillation facility is designed to operate 24 hours a day, 7 days a week, for 300 days each year. Norma 1 activities include: monitoring of the $\mathrm{NO}_{x}, \mathrm{H}_{2} \mathrm{O}, \mathrm{CO}_{2}$, and krypton; maintenance; and replacement.

A1 1 normal process operations are hand led remotely in the hot cel 1. Compressors and pumps are located in normal 1y unoccupied gal leries. Personnel enter the gallery on $1 y$ to insta 11 or remove equipment. Where infrequent operations, instrument readings, and some maintenance activities are needed, personnel may be exposed to higher radiation dose rates. In such cases, the dose rate is control led and 1 imited to 1 ess than $1 \mathrm{mrem} / \mathrm{hr}$.

\subsubsection{Personnel}

Estimates for staffing the krypton recovery system are taken from the DOE (1979a) and presented in Table 3.2 (Details are presented in Table 5.1). These estimates are used to estimate radiation exposures.

\subsection{FLUOROCARBON ABSORPTION}

The al ternative krypton removal system considered for theoretical incorporation into BNFP utilizes fluorocarbon absorption. Fluorocarbon absorption, suggested by Brookhaven National Laboratory (Steiberg 1959), selectively separates krypton and xenon from contaminated off gases. Solubility data have shown that krypton and xenon are much more soluble in dichlorodifluoromethane (refrigerant-12) than are nitrogen, oxygen, and argon. The fluorocarbon absorption process was developed at the Oak Ridge Gaseous Diffusion Plant (Merriman et a1. 1980). The primary objective of the fluorocarbon absorption process development program was to provide a detailed design and economic evaluation of a demonstration off-gas decontamination facility. A pllot facility was built specifically to study the reprocessing $p 1$ ant application. Initial process testing gave positive qualitative results. The pilot facility has been operating for several years now using simulated off gas with only trace amounts of ${ }^{85} \mathrm{Kr}$. Process tests have demonstrated that better than $99.9 \%$ of the krypton and xenon can be removed from off gases. In application, a demonstration plant to handle 
IABLE 3.2. Staffing Requirements for the Cryogenic Distillation System

\begin{tabular}{lc} 
Job Classification & $\begin{array}{c}\text { Personnel Required } \\
\text { man-yr/yr }\end{array}$ \\
\cline { 1 - 2 } Operators & $5^{(a)}$ \\
Radiation Monitors & 1 \\
Maintenance Craftsmen & 2 \\
$\quad$ Total & $\frac{8}{}$
\end{tabular}

(a) Operators receive such a 1 ow radiation dose from this process, they are not considered further.

the anticipated reprocessing $p l$ ant of $f$-gas stream would be designed to remove $99 \%$ of the krypton and $99.9 \%$ of the xenon. The fluorocarbon-based process and peripheral equipment will be defined; optimum operating conditions, including process procedures will be determined; and component and system reliability will be evaluated, including recommendations for necessary support systems. Fluorocarbon absorption is planned for use in the Breeder Reactor Engineering Test (BRET) facility presently to be constructed at DOE Hanford Site.

Serious consideration should be given to the long term use of fluorocarbons. In 1977, the use of fluorocarbons as propel lants in aerosol cans was banned, but they are still used as refrigerants, foaming agents, and cleansers. Although a total ban is highiy unlikely, continued ozone degradation in the atmosphere could bring about additional regulatory restrictions.

\subsubsection{Process and Facilities}

The fluorocarbon absorption system would theoretical ly be expected to occupy a portion of the BNFP as in the case of the cryogenic distillation system (Figure 3.3). The fluorocarbon absorption process would occupy less floor space but would require greater overhead clearance. The reference process design is shown in Figure 3.5 . 


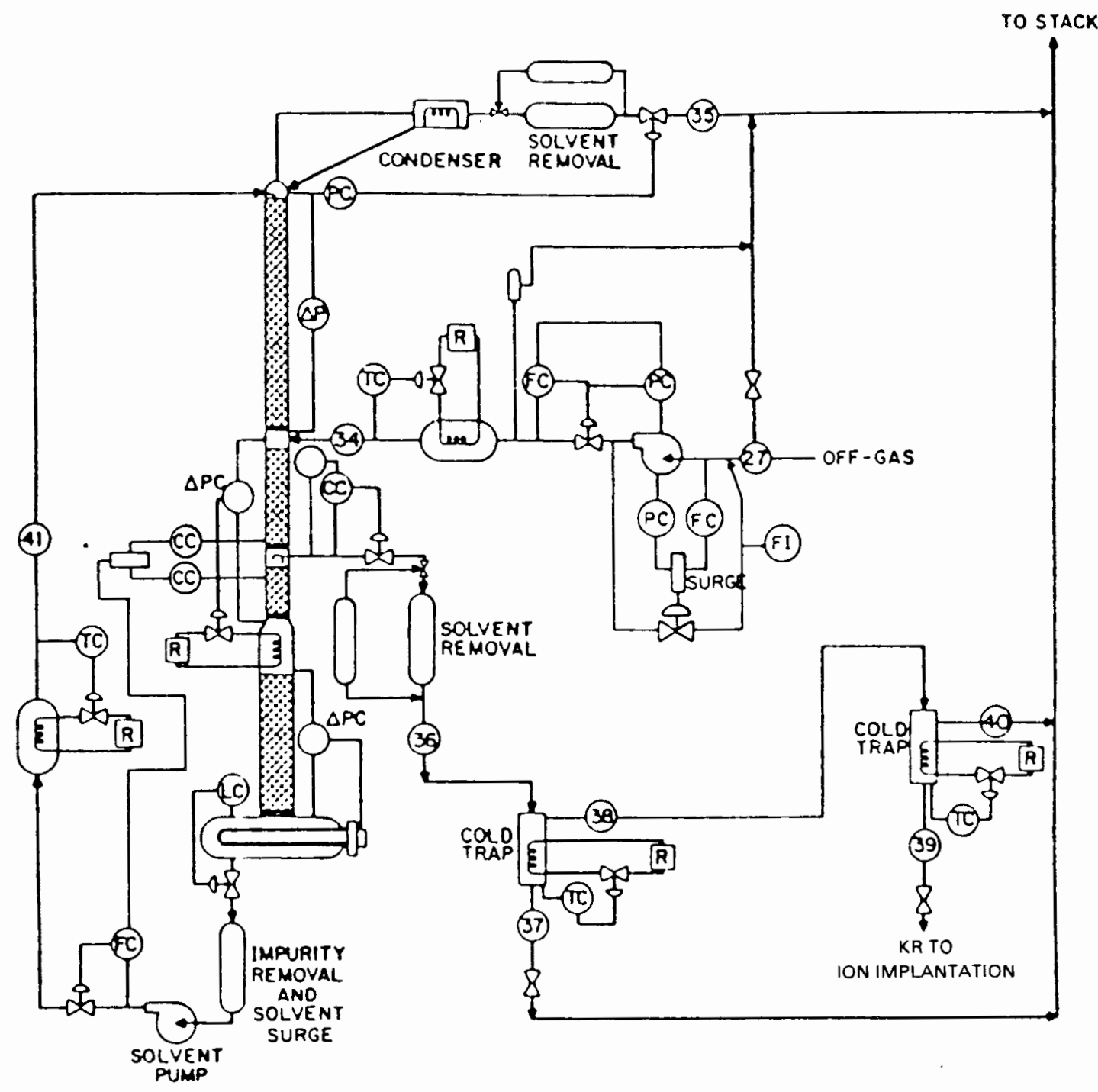

FIGURE 3.5. Fluorocarbon Absorption Process for Krypton Removal (Modified from Merriman et al. 1980)

(Small circled numbers refer to stream numbers given in Table 3.3 ) 
Pretreatment of the feed off gas to remove the oxygen or nitrous oxides, as in cryogenic distillation, is unnecessary for this process. The main components of the fluorocarbon absorption process can be contained in a restricted-access area and include a multifunctional absorber/ fractionator/stripper column, a solvent purification still, and final product purification equipment. Additional support equipment consists of a feed gas heat exchanger, process gas compressor, sol vent pump, solvent cooler, solvent storage tanks, several refrigeration compressors, and a sol vent recovery subsystem to remove the sol vent vapor from the decontaminated process off gas.

The FRP waste off-gas stream is fed into the krypton recovery col umn just below the top part, which is the absorber. In this section, the krypton, xenon, and some air are dissolved in the solvent as it flows down the column. The remaining off gas is vented out the top of the absorber, and any solvent vapor is recovered. The middle of the column serves as the fractionator, where the radioactive components dissolved in the solvent are vaporized and collected as a gas side stream consisting of krypton, xenon, air, and solvent vapor. In the bottom part of the column, the bulk of the solvent is stripped of any remaining dissolved gases and recycled back up to the top of the absorber section. A solvent purification still is needed to purge the solvent of water, nitrogen dioxide, and iodine, which stay dissolved and build up in the solvent. The materials balance for the fluorocarbon absorption system for $95 \%$ of the ${ }^{85} \mathrm{Kr}$ inventory is presented in Tab 1 e 3.3.

As the main krypton stream becomes more and more concentrated in the radioactive components, it presents a radioactive hazard with in the recovery operation. The krypton column, the sol vent recovery system, and the cold traps used to remove the xenon and air from the krypton are a 11 components where krypton will be present in significant quantities and special design considerations will be required. 
TABLE 3.3. Material Balance Flowsheet for Krypton Removal by Fluorocarbon Absorption (a) (Waggoner 1982)

\begin{tabular}{|c|c|c|c|c|c|c|c|c|c|}
\hline STREAM NUMBER: ${ }^{(b)}$ & 27 & 34 & 35 & 36 & 37 & 38 & 39 & 40 & 42 \\
\hline Pressure, atm & 1.0 & 7.3 & 1.0 & 1.0 & 1.0 & 1.0 & 13.6 & 1.0 & 7.3 \\
\hline $\begin{array}{l}\text { Gas, Flow, scfm } \\
\left(\mathrm{ft}^{3} / \mathrm{min}\right)\end{array}$ & $\begin{array}{l}102.6 \\
(118.3)\end{array}$ & $\begin{array}{l}102.2 \\
(12.2)\end{array}$ & $\begin{array}{l}102.1 \\
(109.6)\end{array}$ & $\begin{array}{c}0.1448 \\
(0.1368)\end{array}$ & $\begin{array}{c}0.1306 \\
(0.1211)\end{array}$ & $\begin{array}{l}0.01478 \\
(0.007)\end{array}$ & $\begin{array}{l}0.01431 \\
(0.001)\end{array}$ & $\begin{array}{c}0.0006 \\
(0.0002)\end{array}$ & - \\
\hline $\begin{array}{l}\text { Liquid Flow, } \\
\text { L/day }\end{array}$ & - & - & - & - & - & - & - & - & 74,587 \\
\hline Mass Flow, kg/day & 5700 & 5700 & 5700 & 33.4 & 28.6 & 2.22 & 2.2 & 0.022 & 112,300 \\
\hline $\mathrm{N}_{2}$, kg/day & 4100 & 4086 & 4086 & $1.8 \mathrm{E}-2$ & $1.6 \mathrm{E}-6$ & $1.8 \mathrm{E}-2$ & $6.5 E-4$ & $1.7 \mathrm{E}-2$ & - \\
\hline $\mathrm{O}_{2}, \mathrm{~kg} / \mathrm{day}$ & 1219 & 1219 & 1219 & $7.1 E-3$ & $7.1 \mathrm{E}-7$ & $7.1 E-3$ & $1.0 \mathrm{E}-5$ & $7.1 E-3$ & - \\
\hline Ar, kg/day & 67 & 67 & 67 & $8.6 \mathrm{E}-4$ & $8.6 \mathrm{E}-7$ & $8.6 \mathrm{E}-4$ & $4.0 \mathrm{E}-4$ & $4.0 \mathrm{E}-4$ & - \\
\hline $\mathrm{Kr}, \mathrm{kg} / \mathrm{day}$ & 2.16 & 2.16 & $<0.0216$ & 2.16 & $2.1 E-5$ & 2.16 & 2.16 & 0.0216 & - \\
\hline $\mathrm{N}_{2} \mathrm{O}, \mathrm{kg} /$ day & $6-72$ & 0 & 0 & 0 & 0 & 0 & 0 & 0 & - \\
\hline $\mathrm{CCl}_{2} \mathrm{~F}_{2}(\mathrm{R}-12)$ & - & - & - & - & - & - & - & - & 112,300 \\
\hline
\end{tabular}

(a) Recomputed for an of fgas rate of $100 \mathrm{scfm}$.

(b) Stream numbers refer to circled numbers in Figure 3.5.) 


\subsubsection{Shielding and Special Handling}

Very 1 ittle special hand ling is needed for the fluorocarbon absorption removal process.

In the absorption and fractionation process there is, in effect, no holdup with in the column. Therefore, the radioactivity in the top two sections (about $0.14 \mathrm{Ci} / \mathrm{ft}$ ) does not require additional shielding for a restricted-access area where only infrequent entry is required by plant personne1. The standard $15-\mathrm{cm}$ structural concrete walls are more than adequate to keep the dose rates in adjacent occupied areas below the $1 \mathrm{mrem} / \mathrm{hr}$ design requirement.

The only stage in the removal process requiring special consideration is the final product purification step. The two cold traps used in this design are shielded with one and one-half inches of lead. The dose rate at the surface of the second cold trap is kept to $5 \mathrm{mrem} / \mathrm{hr}$ with the lead shielding, even though the feed stream is $97 \%$ krypton. This is acceptable for the restricted-access area containing the process equipment.

\subsubsection{Qperation and Maintenance}

Under normal operating conditions, the column pressure is held constant, and the solvent flow rate is adjusted to produce the maximum krypton concentration in the solvent at the withdrawal location. This is done by using portable gamma scanning; readings are taken above and below the collector to determine the concentration profile and peak. All operations can be handled remotely from a single operating panel.

Routine maintenance will be required for various pieces of equipment. One infrequent operation requires shutting down the cold traps and purging them, and the column can recycle the xenon and krypton internal ly while this is being carried out. Other equipment, such as pumps and compressors, would be located in a normally unoccupied area where workers would on ly enter to replace or service a piece of equipment. 


\subsubsection{Personnel}

The fluorocarbon absorption recovery process is expected to have the same labor requirement as the cryogenic distillation process. Thus, the personnel 1 isted in Table 3.2 would apply in this case as we 17 , except that it is anticipated that maintenance requirements would decrease by about a factor of 6 .

\subsection{ION IMPLANTATION SPUTIERING}

Ion implantation/sputtering provides an effective batch system for immobilizing krypton gas. The process involves the penetration and retention of krypton ions accelerated into a growing sputter-deposited metal film. One major advantage of this method over competing ones is that it can be achleved at low temperature and pressure. Long-term leakage rates of krypton implanted in solids, extrapolated from short-term, hightemperature measurements, appear to be extremely low (Tingey et a 1. 1979).

Ion implantation/sputtering technology has passed the bench top laboratory scale experimental stage and is now entering the prototype stage. A 1.8 scale-up with remote operations is being developed at Pacific Northwest Laboratory.

\subsubsection{Process and Facilities}

The ion implantation process involves implanting gases into solids by bombarding the surface of the solid with energetic fons. Positively charged krypton ions are created by collisions between energetic electrons and krypton gas atoms. These positively charged krypton ions, the sputtering ions, are accelerated to the target by applying a large negative voltage to the target. The krypton ions are also accelerated to the substrate to implant in the sputtering deposit by applying a lesser negative voltage to the substrate. A schematic of the process is presented in Figure 3.6.

The process feed gas from the fluorocarbon absorption system is assumed to be $2 \%$ xenon, $8 \%$ argon and 90\% krypton by weight (RMP 1981). The $6 \%{ }^{85} \mathrm{Kr}$ in the gas streams becomes $0.86 \%$ after 30 years' decay. This gas 


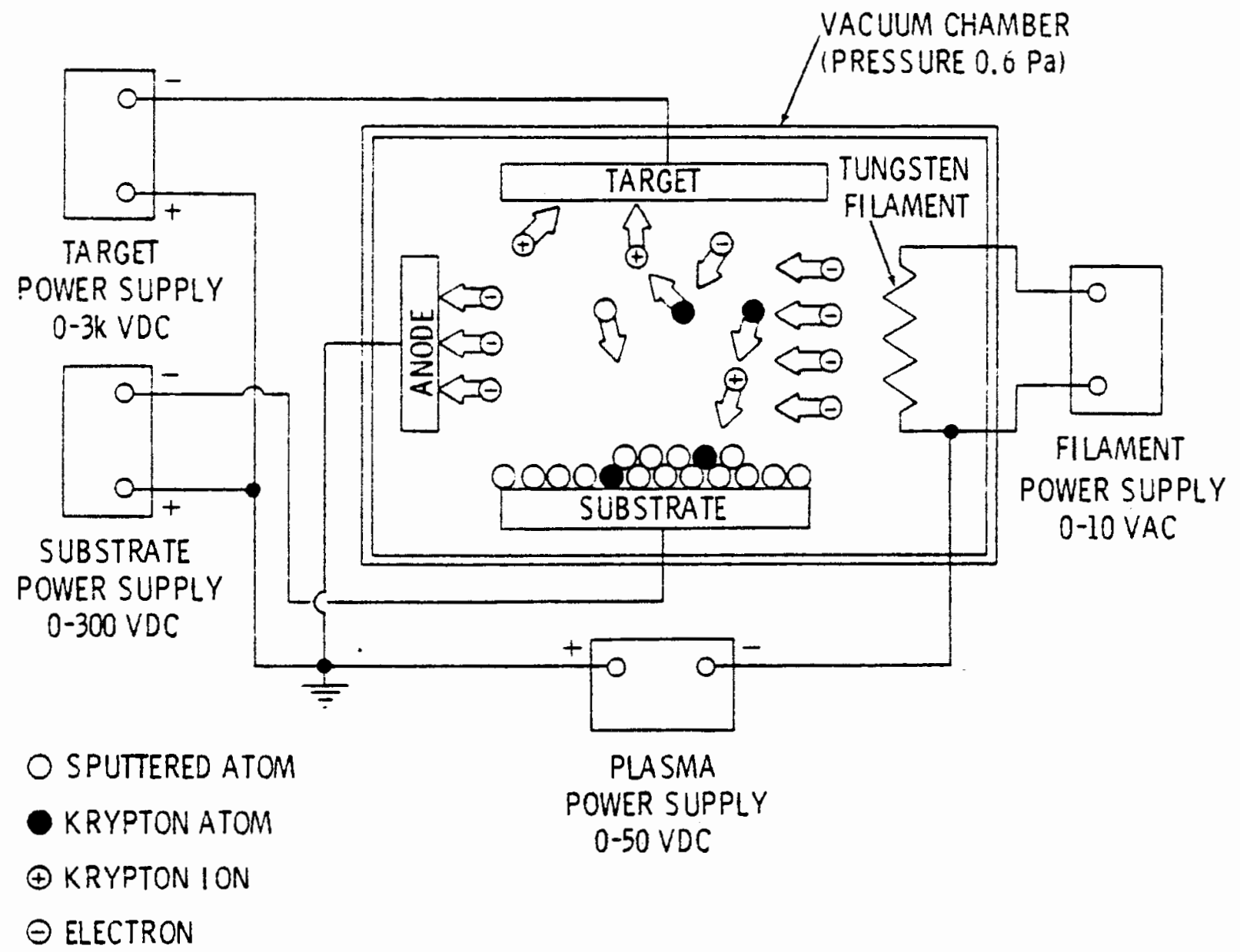

FIGURE 3.6. Themionicaliy Supported Plasma Sputtering/Ion Implantation Components (Tingey et al. 1979) 
composition is the basis for the radiation dose calculations for fluorocarbon absorption and ion implantation/sputtering.

The depth of implantation amounts to on $1 y$ a few atom layers for ion energies in the keV range. To produce large quantities of a solid containing high concentrations of krypton, it is necessary to perform the implantation during film growth by a vapor deposition process such as sputtering where implanted krypton fons are entrapped by the growing sputter deposit. The resulting deposited solid, based on analysis of laboratory scale process deposits, incorporates up to about $13 \%$ krypton by weight.

Leakage rates of krypton implanted in solids depend on four diffusion mechanisms discussed by knecht (1977). Low temperature leakage can be minimized by avoiding structural damage during ion implantation.

The long-term release of $85 \mathrm{Kr}$ from two amorphous metal deposits was also investigated as a function of temperature by Tingey et al. (1979) as shown in Table 3.4. These values were extrapolated from short-term, hightemperature measurements. Although long-term tests are needed to confirm these results, it appears that the loss of $85 \mathrm{Kr}$ will be negligible at temperatures below $300^{\circ} \mathrm{C}$. These data also suggest that packaging this material in additional metal containers may not be necessary. These release rates are so 1 ow that storage of ${ }^{85} \mathrm{Kr}$ immobilized in sputtered metals can be accomplished without any significant environmental contamination.

Several matrix materials have been studied and summarized by Tingey et a 1. (1979). One major advantage of this method over its closest competitor, encapsulation into sodalites, is that it can be achieved at low temperature at low pressure (Bayne et a1. 1978).

IABLE 3.4. Fraction of ${ }^{85} \mathrm{Kr}$ Released in 100 Years

$\begin{array}{llllll}\mathrm{Fe}_{0.79 \mathrm{Y}_{0.12} \mathrm{Kr}_{0.09}} & \frac{200^{\circ} \mathrm{C}}{1.1 \times 10^{-5}} & \frac{300^{\circ} \mathrm{C}}{2.4 \times 10^{-2}} & \frac{400^{\circ} \mathrm{C}}{8.5 \times 10^{-1}} \\ \mathrm{Fe}_{0.75 \mathrm{Zr}_{0.19} \mathrm{Kr}_{0.06}} & 7.5 \times 10^{-7} & 6.6 \times 10^{-4} & 7.1 \times 10^{-2}\end{array}$


The ion implantation/sputtering facility is assumed to be a separate facility tied into the BNFP through a shielded transport pipeline from the cryogenic distillation or fluorocarbon absorption facility. However, this facility shares utilities, laboratories, and health physics support with the FRP. The ion implantation/sputtering facility has sufficient capacity to handle the total krypton gas output of the cryogenic facility. A floor plan of the facility as proposed by Parsons and modified by the authors is shown in Figure 3.7. Modifications to Interim Product Storage were necessary to provide $61-\mathrm{cm}$ concrete shielding to reduce the dose equivalent rate to the design 1 evel of $1 \mathrm{mrem} / \mathrm{hr}$ as required by ERDA Manual Chapter 6301 (ERDA 1974 ).

The ion implantation/sputtering facility is a rectangular building with overall dimensions of about $27 \mathrm{~m}$ by $15 \mathrm{~m}$. The building is constructed of reinforced concrete for al 1 areas required to survive design basis natural phenomena. Areas required to survive design basis natural phenomena are those areas of the building necessary for containment of ${ }^{85} \mathrm{Kr}$. Other areas of the building are constructed of reinforced masonry concrete block wal 1s with roofing over metal decking supported by structural stee 1 beams, and are required to survive operating basis natural phenomena.

The facility is on two levels. Power supplies to the process and heating and ventilation equipment are located on the second level, which measures about $27 \mathrm{~m}$ by $9 \mathrm{~m}$.

\subsubsection{Shielding and Special Handling}

Information about operating areas, support areas, and shielding specifications (Figure 3.7 and Tab 1e 3.5), along with extensive design information concerning certain functional areas within the plant was used for the occupational radiation dose assessment presented in Section 5 .

The original design contained in the preconceptual design (RMP 1981) provided for a 60-day operational supply of feed gas. This design was for the operation of the zeolite absorption process and is unnecessary for the ion implantation/sputtering process, which requires small quantities of 


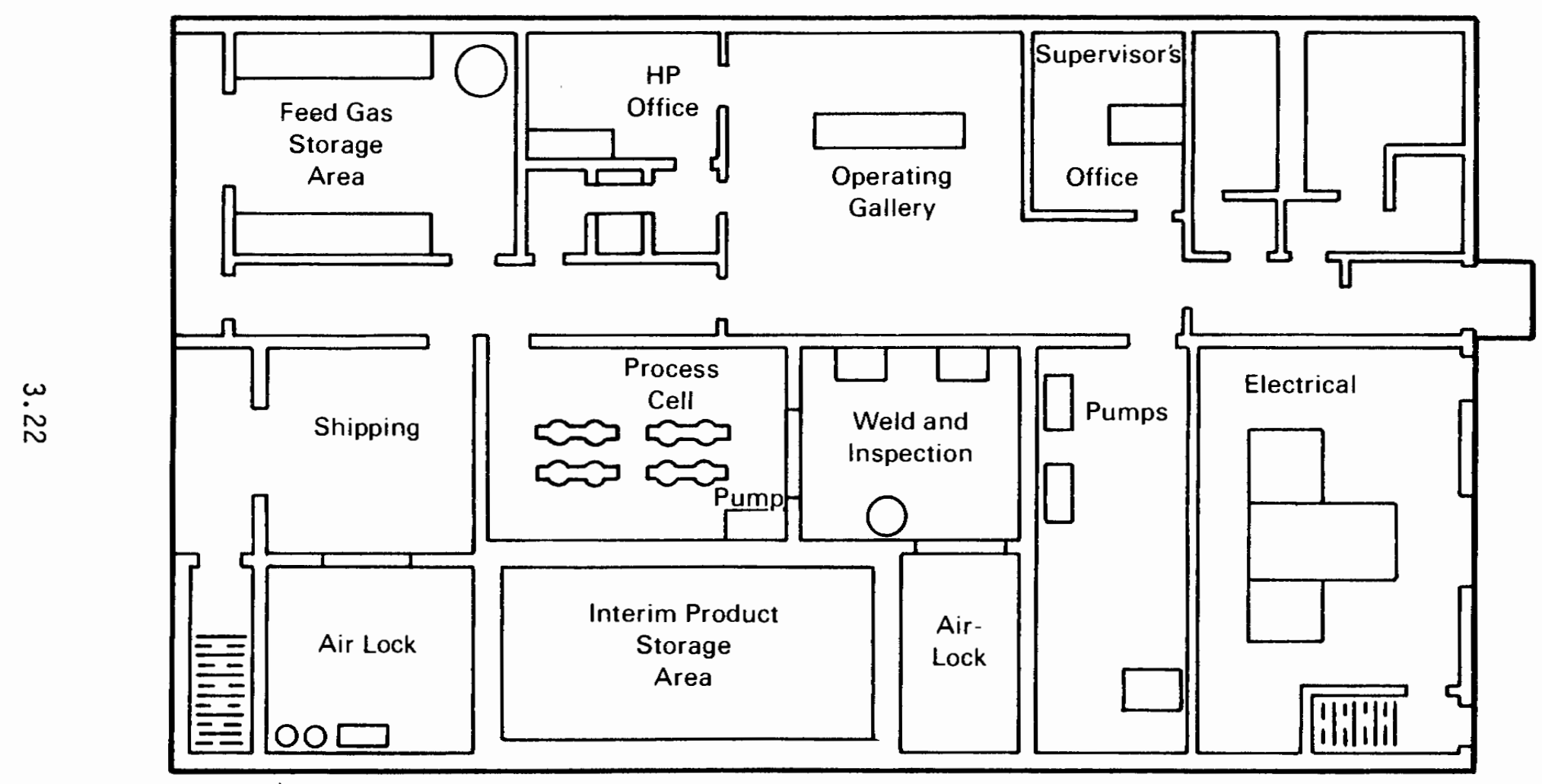

FIGURE 3.7. Modified Floor Plan of Ion Implantation/Sputtering Facility (RMP 1981) 
IABLE 3.5. Operating and Support Areas and Shielding Specifications

\begin{tabular}{|c|c|c|c|}
\hline Facility Area & Area $\left(m^{2}\right)$ & $\begin{array}{l}\text { Shielding } \\
\text { thickness } \\
(\mathrm{cm}) \\
\end{array}$ & Type of material \\
\hline Feed Gas Storage Area & 20 & $\begin{array}{l}61 \\
61\end{array}$ & $\begin{array}{l}\text { reinforced concrete walls } \\
\text { \& ceiling, concrete floor }\end{array}$ \\
\hline Process Cell & 43 & $\begin{array}{l}30 \\
15\end{array}$ & $\begin{array}{l}\text { reinforced concrete walls } \\
\text { \& ceiling, concrete floor }\end{array}$ \\
\hline $\begin{array}{l}\text { Interim Product Storage } \\
\text { Area }\end{array}$ & 32 & $\begin{array}{l}61 \\
61\end{array}$ & $\begin{array}{l}\text { reinforced concrete walls } \\
\text { \& ceiling, concrete floor }\end{array}$ \\
\hline
\end{tabular}

feed gas at 1 ow pressure. Therefore, the 1 ag gas storage area was eliminated and was replaced by a room used for loading canisters for shipment. A single pressure vessel and low-pressure compressor/pump is located in an air lock to collect and store any feed gas that must be purged from other pieces of equipment before contact maintenance is performed.

During normal operations, $47 \mathrm{~L} / \mathrm{hr}$ of $10 \mathrm{w}$-pressure feed gas is de1 ivered to the Precess Cell for implantation. The krypton encapsulation facility is designed with eight process units $(27 \mathrm{~cm}$ by $42-\mathrm{cm}$ long) containing a target/substrate assembly. Each unit operates as a batch process, with a calculated processing time of 129 hours, and entraps 34 moles (760 L at standard temperature and pressure (STP) of krypton as the nicke1lanthanum al loy is removed from the substrate and is deposited on the water-cooled target. The deposit weighs about $22 \mathrm{~kg}$ and contains some $2.9 \mathrm{~kg}$ of entrapped gas. Assuming that the krypton contains $0.86 \%$ (30 years' decay) ${ }^{85} \mathrm{Kr}$, each assemb $7 y$ contains about $9.8 \times 10^{3} \mathrm{Ci}$ of $85 \mathrm{Kr}$. Shielded viewing windows are provided for remote operations, substrate inspection, and substrate sealing. An overhead bridge crane services the cell for loading, unloading, and transporting substrate containers. New target/substrate assemblies can be installed in the cell either manually or remotely. The substrate is a standard $25-\mathrm{cm}$ stainless steel pipe and pipe cap, which, when seal welded after processing, provides containment of the encapsulated deposit. The target/substrate assemblies are shielded by $5 \mathrm{~cm}$ of lead or equivalent, so that personnel can enter the room in case of equipment malfunction. 
Once the krypton is incorporated into the sputtered metal and the substrate/target assemblies are welded shut, the product canister is purged and filled with helium through a connection provided for this purpose. The canisters are leak-checked and then transported to the Interim Product Storage Area. The storage area has the capacity to store encapsulated product captured during one year's operation. The storage rack holds product canisters in a six-by-six horizontal array, to al low cooling by natural convection. The storage rack can accommodate a total of 468 canisters. Inserted product canisters push other canisters in the same position along the length of the storage rack, thereby exposing the oldest canisters at the end of the storage rack. These older canisters are then transported to long-term storage. Shielded hatches are provided for canister maintenance. Because of the radiation levels, the wal is of the product storage area must be $61 \mathrm{~cm}$ thick to provide adequate shielding for the storage of canisters from one year's operation (if necessary) of the encapsulation facility.

Target, substrate, and filament assemblies are received and stored in the Substrate Storage Area. They are fabricated and tested offsite and shipped to the encapsulation facility as an assembled unit. A total of about 300 assemblies/yr are utilized to encapsulate about 10,000 moles $(232,500 \mathrm{~L})$ of feed gas per year. Existing shipping containers do not provide adequate shielding for the krypton activity $\left(9.8 \times 10^{3} \mathrm{Ci}\right)$ expected for canister loading. Containers with increased shielding must be provided; otherwise it will be necessary to reduce the ${ }^{85} \mathrm{Kr}$ inventory per canister and handle more than 1000 canisters per year.

\subsubsection{Operation and Maintenance}

The krypton encapsulation facility is designed with eight process units. Each unit operates as a batch process, with a calculated processing time as discussed in section 3.5.2. The equipment operates $24 \mathrm{hr} /$ day, 300 days/yr, with a required availability of approximately $70 \%$ while the facility is in operation. The facility is designed to have a 30-year 1 ife. 


\subsubsection{Personnel}

Estimated staffing requirements for the ion implantation/sputter process are presented in Table 3.6. In addition, other workers will enter the facility for janitorial service.

\subsection{STORAGE SCENARIQ}

In view of the lack of provision for ${ }^{85} \mathrm{Kr}$ in criteria for final emp lacement of radioactive wastes, it has been concluded that disposal of the 1 arge amounts of $85 \mathrm{Kr}$ from FRPs cannot be carried out at the present time (Trevorrow et al. 1983). Therefore, we assume that a large concrete surface retrievable storage facility is colocated with the FRP. The facility is cooled by convective air and therefore requires no regular maintenance schedule. We therefore assume no additional exposure from this retrievable storage facility.

\section{IABLE 3.6. Staffing Requirements for the Ion} Imp 1 antation/Sputtering Facil ity

Job Classification

Supervisor

Operators

Radiation Monitor

Maintenance Craftsmen

Total
Personnel Required man-yr/yr

l(a)

2

0.5

1

4.5

(a) The supervisor receives such a low radiation dose from this process that he is not considered further. 


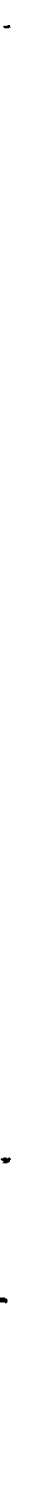




\subsection{IHE BARNWELL NUCLEAR FUEL PLANT ENYIRONMENT}

\subsection{THE SITE}

The BNFP site, located on a 1706-acre tract of 1 and (AGNS 1971), is the representative site for this study. The site is contiguous to the eastern boundary of the DOE's Savannah River Plant (SRP). A site plot plan is shown in Figure 3.2. The land is generally level, with a gently rolling surface, and is heavily wooded with pines and some native hardwood and softwood trees. Portions of the pines were previously harvested. There are no surface streams on the site, and wel1-defined surface run-off features are essentially absent (Figure 4.1). About 135 acres of the site have been cleared for construction activities. Other site improvements include the 15-acre Beacon cool ing water, ecological monitoring, and condition pond for 1 iquid effluent releases to Lower Three Runs Creek. A meteorological tower is located near the southwest corner of the main process area.

Authorities on ${ }^{85} \mathrm{Kr}$ dosimetry agree that the dose from noble gases absorbed in tissue is general1y smal1 compared to the dose from direct external radiation and from inhalation (Soldat et a 1. 1976). Therefore, this analysis requires only information on regional population distribution and site-specific meteorology.

\subsection{REGIONAL DEMOGRAPHY}

The BNFP is a part of the Barnwel 1 Nuclear Industrial Park. The other nuclear industry currently in the immediate area is Chem-Nuclear Services, Inc., which is engaged in 1 and disposal of low-level radioactive waste and noxious chemicals. Other areas surrounding the site are predominantly rural or restricted as part of the SRP. Agricultural activities are declining. There is a trend toward industrial economy.

The population of Barnwel 1 county has declined in the past two decades. The urban areas with populations greater than 1000 individuals with in a $10-\mathrm{mile}(16-\mathrm{km})$ and a $50-\mathrm{mile}(80-\mathrm{km})$ radius of the BNFP are shown in Figures 4.2 and 43 , respectively. There are no cities within a 25-mile 


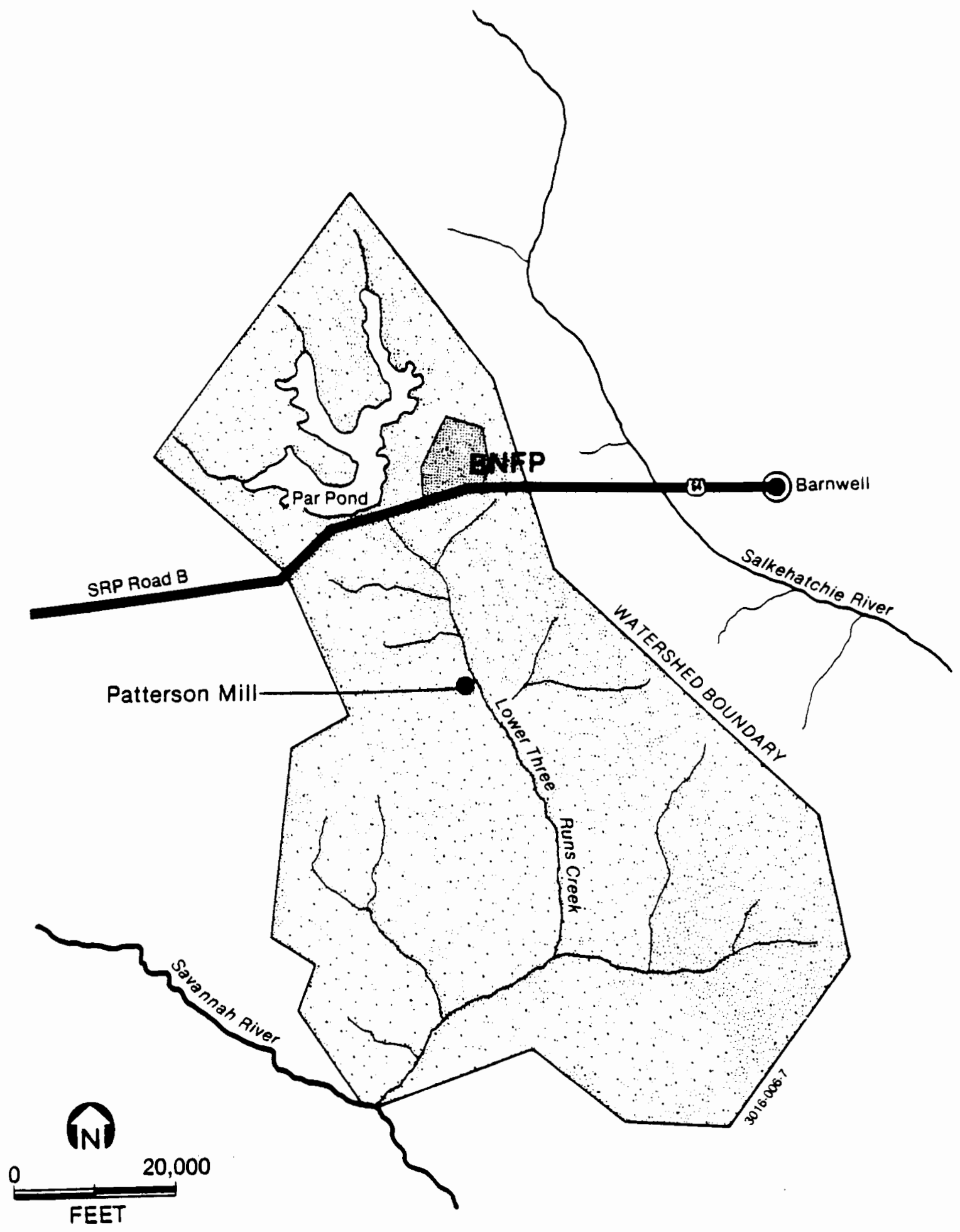

FIGURE 4.1. Lower Three Runs Creek Watershed (NRC 1975) 


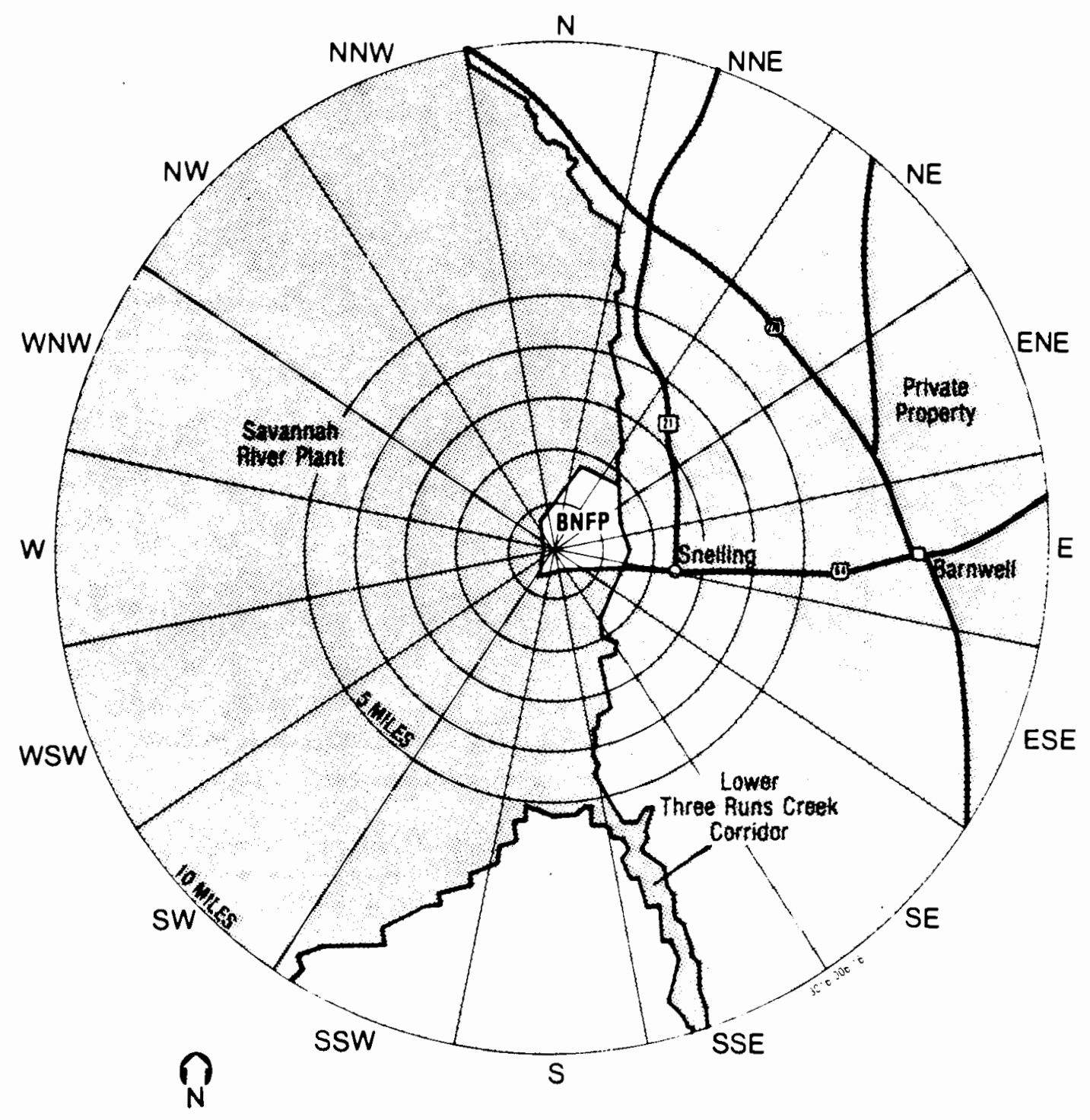

FIGURE 4.2. Sector Detail Within First 10 Miles from BNFP Process Area 


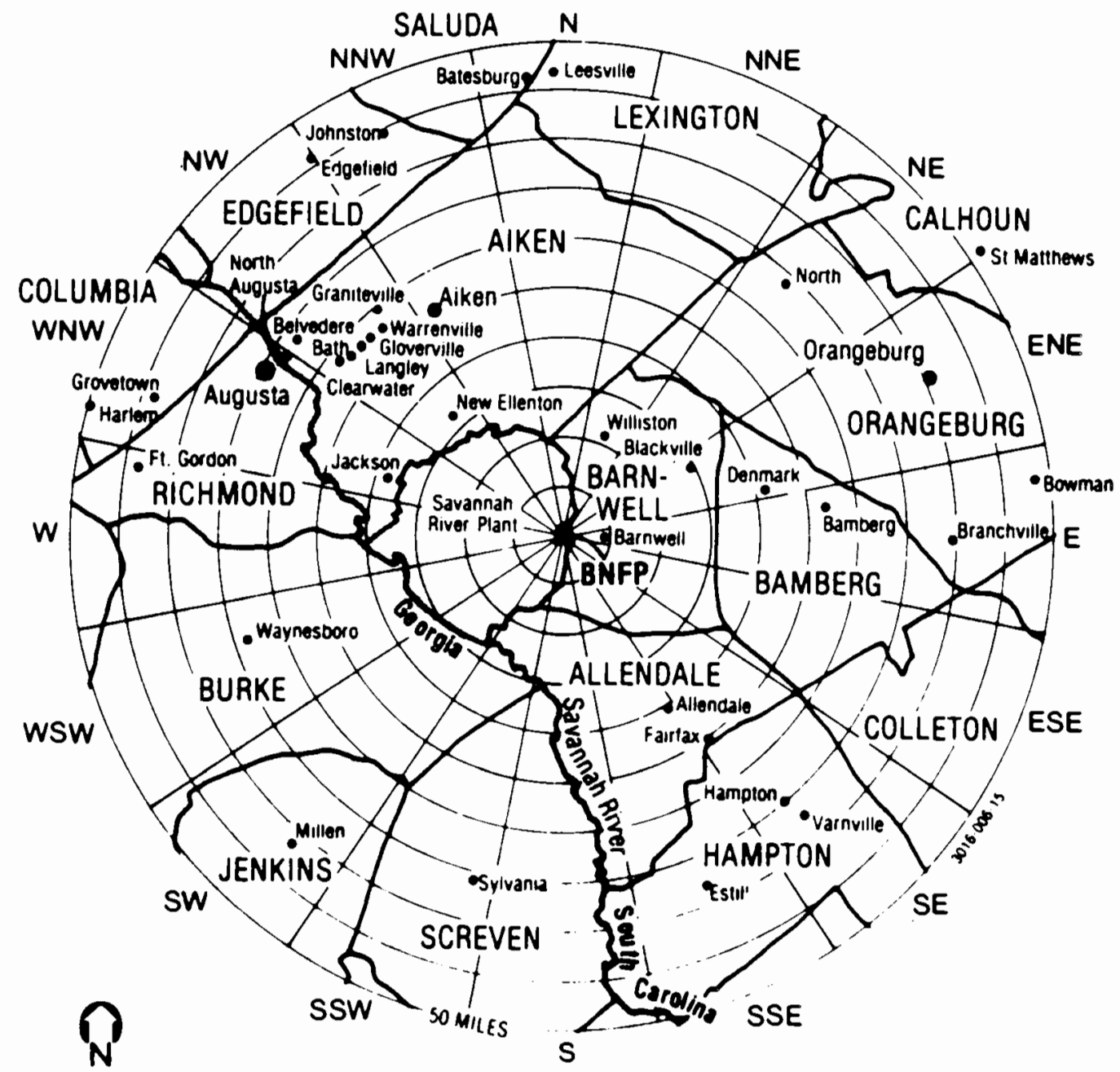

FIGURE 4.3. Urban Areas Greater Than 1000 Population Within 50 Miles of the BNFP

NOTE: See Figure 4.2 for details within first 10 miles 
radius with a population in excess of 5000. The nearest cities of any size are Aiken, South Carol ina (population 16,125), which is about 26 miles NW; Augusta, Georgia (population 59,864), located $33 \mathrm{miles} W \mathrm{WW}$; and Orangeburg, South Carolina (population 13,252), located about $39 \mathrm{miles}$ ENE of the BNFP site. The total 1970 population within 25 miles is 65,209. The projected 1980 population estimate is 79,000 . The tota 11970 population within a 50mile radius of the site is 499,000, and the projected 1980 estimate is 658,000. In this scenario, the BNFP is to begin operation in about the year 2000. The projected year 2005 population distribution (Table 4.1) was selected for calculating of the population doses because it was the closest readily available estimate to our operation scenario.

\subsection{REGIONAL METEOROLOGY}

The BNFP release of process gaseous effluents is from a $100-m$ stack. There are no hills or valleys in the vicinity that would tend to channel air flow or create mechanical turbulence. There are no bodies of water in the vicinity of sufficient size to create atmospheric diffusion problems associated with a water-land transition zone.

On the basis of the Gaussian distribution equation and the frequency of wind speed and direction for Pasquil 1 categories $A$ through $G$ for the years 1972, 1975, and 1980, annual average atmospheric dispersion factors for airborne material from the 100-m stack were calculated(a) and presented in Tab 1 e 4.2 .

(a) Boone, F. W. 1982. Al lied-General Nuclear Services, Barnwel 1, South Carolina. Memorandum to file, Number ENV C.1, SEC/81/205, Revision 1 , January 21. 
IABLE 4.1. 2005 Population Distribution Estimates Within 50 Miles of the BNFP (see footnote, p. 4.5)

\begin{tabular}{|c|c|c|c|c|c|c|c|c|c|c|}
\hline $\begin{array}{c}\text { Direction } \\
\text { To }\end{array}$ & $1-2 \mathrm{mi}$ & $2-3 \mathrm{mi}$ & $3-4$ mi. & $4-5 \mathrm{mi}$ & $5-10$ mi. & $10-20 \mathrm{ml}$. & $20-30 \mathrm{~m} 1$. & $30-40 \mathrm{mi}$. & $40-50 \mathrm{mi}$. & TOTAL \\
\hline$N$ & 0 & 0 & 0 & 0 & 176 & 4,188 & 6,980 & $9,77 !$ & 35,395 & 56,510 \\
\hline NNE & 0 & 0 & 17 & 34 & 352 & 5,848 & 6,980 & 20,123 & 25,872 & 59,226 \\
\hline$N E$ & 0 & 0 & 32 & 43 & 352 & 1,412 & 7,787 & 12,741 & 10,826 & 33,193 \\
\hline ENE & 0 & 0 & 32 & 43 & 352 & 12,126 & 6,000 & 33,562 & 12,091 & 64,206 \\
\hline$E$ & 9 & 17 & 32 & 43 & 7,943 & 1,924 & 9,639 & 10,048 & 15,889 & 45,544 \\
\hline $\mathrm{ESE}$ & 9 & 342 & 32 & 43 & 352 & 1924 & 3,815 & 4,921 & 6,163 & 17,601 \\
\hline SE & 9 & 17 & 32 & 43 & 352 & 1,170 & 5,624 & 11,508 & 5,123 & 23,878 \\
\hline SSE & 0 & 0 & 26 & 43 & 352 & 7,187 & 1,660 & 7,326 & 5,123 & 21,717 \\
\hline$S$ & 0 & 0 & 0 & 0 & 352 & 997 & 2,079 & 3,393 & 4,362 & 11,183 \\
\hline SSW & 0 & 0 & 0 & 0 & 125 & 1,315 & 2,423 & 8,863 & 4,362 & 17,088 \\
\hline SW & 0 & 0 & 0 & 0 & 0 & 899 & 2,568 & 3,093 & 10,328 & 16,888 \\
\hline WSW & 0 & 0 & 0 & 0 & 0 & 450 & 2,568 & 13,051 & 4,622 & 20,691 \\
\hline$W$ & 0 & 0 & 0 & 0 & 0 & 814 & 23,747 & 33,244 & 69,400 & 127,205 \\
\hline WNW & $\overline{0}$ & 0 & 0 & 0 & 0 & 4,518 & 6,980 & 191,570 & 26,416 & 229,484 \\
\hline $\mathrm{NW}$ & 0 & 0 & 0 & $\overline{0}$ & 0 & 6,797 & 50,737 & 7,257 & 11,231 & 76,022 \\
\hline NNW & 0 & 0 & 0 & 0 & 0 & 4,188 & 6,980 & 9,771 & 11,809 & 32,748 \\
\hline TOTAL & 27 & 376 & 203 & 292 & 10,708 & 55,757 & 146,567 & 380,242 & 259,012 & 853,184 \\
\hline
\end{tabular}


IABLE 4.2. Annual Average Atmospheric Dispersion Factors for the BNFP Separations Facility Main Stack(a)

CHI/Q (SEC/METER CUBED) FOR EACH SEGMENT DIR.FR.SITE .5-1

$\begin{array}{rlll}N & 5.987 \mathrm{E}-09 & 6.241 \mathrm{E}-09 & 7.200 \mathrm{E}-09 \\ \text { NNE } & 9.897 \mathrm{E}-09 & 8.738 \mathrm{E}-09 & 8.588 \mathrm{E}-09 \\ \mathrm{NE} & 1.474 \mathrm{E}-08 & 1.012 \mathrm{E}-08 & 9.144 \mathrm{E}-09 \\ \mathrm{ENE} & 1.916 \mathrm{E}-08 & 1.211 \mathrm{E}-08 & 1.031 \mathrm{E}-08 \\ \mathrm{E} & 2.224 \mathrm{E}-08 & 1.346 \mathrm{E}-08 & 1.139 \mathrm{E}-08 \\ \mathrm{ESE} & 2.085 \mathrm{E}-08 & 1.269 \mathrm{E}-08 & 1.107 \mathrm{E}-08 \\ \mathrm{SE} & 1.275 \mathrm{E}-08 & 8.378 \mathrm{E}-09 & 7.438 \mathrm{E}-09 \\ \text { SSE } & 8.346 \mathrm{E}-09 & 6.134 \mathrm{E}-09 & 5.301 \mathrm{E}-09 \\ \mathrm{~S} & 5.465 \mathrm{E}-09 & 5.126 \mathrm{E}-09 & 5.037 \mathrm{E}-09 \\ \text { SSW } & 7.301 \mathrm{E}-09 & 7.867 \mathrm{E}-09 & 8.200 \mathrm{E}-09 \\ \text { SW } & 7.309 \mathrm{E}-09 & 9.416 \mathrm{E}-09 & 1.060 \mathrm{E}-08 \\ \text { WSW } & 7.913 \mathrm{E}-09 & 9.432 \mathrm{E}-09 & 1.021 \mathrm{E}-08 \\ \text { W } & 5.970 \mathrm{E}-09 & 7.172 \mathrm{E}-09 & 8.107 \mathrm{E}-09 \\ \text { WNW } & 5.149 \mathrm{E}-09 & 5.769 \mathrm{E}-09 & 6.401 \mathrm{E}-09 \\ \text { NW } & 4.760 \mathrm{E}-09 & 5.826 \mathrm{E}-09 & 6.515 \mathrm{E}-09 \\ \text { NNW } & 4.322 \mathrm{E}-09 & 5.497 \mathrm{E}-09 & 6.508 \mathrm{E}-09\end{array}$

\section{SEGMENT BOUNDARIES IN MILES}

3-4 4-5 5-10

\section{$7.498 \mathrm{E}-09 \quad 7.289 \mathrm{E}-09$ \\ $5.770 E-09$}

$8.303 \mathrm{E}-09 \quad 7.798 \mathrm{E}-09$

$5.985 \mathrm{E}-09$

$5.948 \mathrm{E}-09$

$8.550 E-09$

7.897E-09

8.388E-09

$6.144 \mathrm{E}-09$

$1.009 \mathrm{E}-08$

$8.972 \mathrm{E}-09$

$6.418 \mathrm{E}-09$

$1.015 \mathrm{E}-08$

$9.248 \mathrm{E}-09$

$6.889 \mathrm{E}-09$

$6.707 \mathrm{E}-09$

$6.014 \mathrm{E}-09$

$4.355 \mathrm{E}-09$

4.671E-09

4.130E-09

2.916E-09

$4.188 \mathrm{E}-09$

$7.687 \mathrm{E}-09$

$6.872 \mathrm{E}-09$

$2.984 \mathrm{E}-09$

4.673E-09

$6.425 \mathrm{E}-09$

$1.022 \mathrm{E}-08$

$9.264 \mathrm{E}-09$

8.948E-09

$6.313 \mathrm{E}-09$

5.644E-09

8.106E-09

7.601E-09

$6.435 \mathrm{E}-09$

6.117E-09

$4.719 \mathrm{E}-09$

$4.659 \mathrm{E}-09$

6.697E-09

4.901E-09
$10-20$

3.556E-09

3.616E-09

3. $535 \mathrm{E}-09$

3.597E-09

$3.683 \mathrm{E}-09$

4.124E-09

$2.545 \mathrm{E}-09$

$1.649 \mathrm{E}-09$

$1.683 \mathrm{E}-09$

2.430E-09

$3.420 \mathrm{E}-09$

3.429E-09

$3.265 \mathrm{E}-09$

2.882E-09

$2.732 \mathrm{E}-09$

2.896E-09

$$
20-30
$$

$30-40$

$40-50$

$2.268 \mathrm{E}-09$
$2.295 \mathrm{E}-09$
$2.295 E-09$
$2.229 E-09$

2.267E-09

2.301E-09

2.638E-09

$1.613 \mathrm{E}-09$

$1.023 \mathrm{E}-09$

$1.034 \mathrm{E}-09$

$1.404 \mathrm{E}-09$

$1.999 \mathrm{E}-09$

2.030E-09

$2.014 \mathrm{E}-09$

$1.846 \mathrm{E}-09$

$1.696 \mathrm{E}-09$

$1.799 \mathrm{E}-09$
$1.623 E-09$

$1.642 \mathrm{E}-09$

$1.595 \mathrm{E}-09$

$1.624 \mathrm{E}-09$

$1.640 \mathrm{E}-09$

$1.903 \mathrm{E}-09$

$1.160 \mathrm{E}-09$

$7.266 \mathrm{E}-10$

$7.271 \mathrm{E}-10$

9.563E-10

$1.366 \mathrm{E}-09$

$1.399 \mathrm{E}-09$

$1.417 \mathrm{E}-09$

$1.324 \mathrm{E}-09$

$1.196 \mathrm{E}-09$

$1.269 \mathrm{E}-09$
$1.247 \mathrm{E}-09$

$1.264 \mathrm{E}-09$

$1.230 \mathrm{E}-09$

$1.253 \mathrm{E}-09$

$1.260 \mathrm{E}-09$

$1.475 \mathrm{E}-09$

8.974E-10

$5.570 \mathrm{E}-10$

$5.528 \mathrm{E}-10$

$7.130 \mathrm{E}-10$

$1.018 \mathrm{E}-09$

$1.049 \mathrm{E}-09$

$1.077 \mathrm{E}-09$

1.019E-09

9.105E-10

9.667E-10

(a) Boone, F. W. 1982. Allied-General Nuclear Services, Barnwell, South Carol ina. Memorandum to Files, "Update of Gasious Effluent-Dose Commitment Analysis Documentation," ENV C.1, SEC/81/205 Rev.1.

January 21 , Table 5 . 



\subsection{KRYPTON-85 DOSE COMMITMENTS}

The radiation dose due to ${ }^{85} \mathrm{Kr}$ received by individual members of the public will be reduced proportionately with the recovery percentage of ${ }^{85} \mathrm{Kr}$ at the FRP. However, to recover and immobilize ${ }^{85} \mathrm{Kr}$, systems have to be purchased and installed, expending capital. In addition, the systems will have to be routinely operated and maintained, thereby expending additional do 1 lars and increasing radiation dose commitment to individuals of the workforce. The recovered ${ }^{85} \mathrm{Kr}$ may subsequently be transported onsite and stored, again resulting in additional cost and additional occupational radiation exposure. The population groups of concern receiving most significant radiation doses are the occupationa 1 workforce, the maximum individual in the public sector, and the $50-\mathrm{mille}(80-\mathrm{km})$ population. These trade-offs are now examined individual ly. A world dose calculation is considered meaningless because the individual radiation dose has been calculated to be less than $0.0007 \mathrm{mrem} / \mathrm{yr}$ (Mel linger et a 1. 1980) for a higher ${ }^{85} \mathrm{Kr}$ release than is being considered here.

\subsection{OCCUPATIONAL DOSES FROM ${ }^{85} \mathrm{Kr}$ RECOVERY AND IMMOBILIZATION}

Cryogenic distillation and fluorocarbon absorption have been chosen as alternative reference processes for recovery of the BNFP $85 \mathrm{Kr}$. The details of these processes are given in Section 3. The radiation exposures and estimated doses for the workforce from these processes are given here.

\subsubsection{Occupational Doses from Cryogenic Distillation Facility}

There are several ways by which workers in the cryogenic distillation facility can receive radiation dose. First, the worker can receive an internal dose from air contaminated with ${ }^{85} \mathrm{Kr}$. However, it is assumed that negative air balances are maintained, such that a worker receives a negligible inhalation dose. Al1 areas in which the worker may be exposed to $85 \mathrm{Kr}$ will be purged before workers enter. If some airborne krypton remains, workers may be required to wear respiratory protection (supplied air) to reduce or eliminate the potential for inhalation of $85 \mathrm{Kr}$. 
The second mechanism is the direct exposure to the gamma rays emitted during the decay of $85 \mathrm{Kr}$. The reference cryogenic distillation facility is wel 1-shielded and worker exposures are minimized. The general plan of the DOG system is given in Figure 5.1 along with the dose equivalent rates in $\mathrm{mrem} /$ hour at various work locations. Under normal operating conditions, the highest dose rate is on 1 y $0.015 \mathrm{mrem} /$ hour through the $1-\mathrm{m}$-thick concrete wal1s. It is estimated that a worker would only receive 10 mrem per year working around the shielded cryogenic distillation system. Workforce time estimates are presented in Table 3.2.

The majority of the dose to workers from cryogenic distillation is from maintenance operations on equipment in the hot cel 1s. In order to minimize the workers' exposure, preventative maintenance can be performed on a scheduled basis, after the facility has been shut down and the system has been purged of $85 \mathrm{Kr}$. Breakdown repairs can be handled two ways. The first is to purge the equipment of al $1{ }^{85} \mathrm{Kr}$. Since it requires almost a full day to warm up the cryostat, this method could result in the system being out of commission for two full days or more. The second method is to enter the hot cel 1 and work very rapidly to remove modular equipment so that it can be moved to a shop outside the radiation zone. If $85_{\mathrm{Kr}}$ is not removed from the cold box, the second method can lead to high exposures. To minimize the radiation doses during breakdown maintenance, it is assumed that critical systems, such as compressors, transducers, and 1 iquid level indicators, will have redundant back-up units to minimize down-time.

The equipment used in the krypton recovery facility and the maintenance requirements used for calculating radiation doses are shown in Table 5.1. These maintenance estimates were provided by Pacific Northwest Laboratory (PNL) Maintenance and Craft Services. The ${ }^{85} \mathrm{Kr}$ inventories in each piece of equipment were determined from data taken from Brown, knecht and Thomas (1978). The resulting dose rates were calculated. Depending upon the assumed amount of shielding around the cold box and whether the cold box is shut down for two days and purged of a $11{ }^{85} \mathrm{Kr}$, the doses can vary from 467 man-rem per year to 0.28 man-rem per year as shown in 


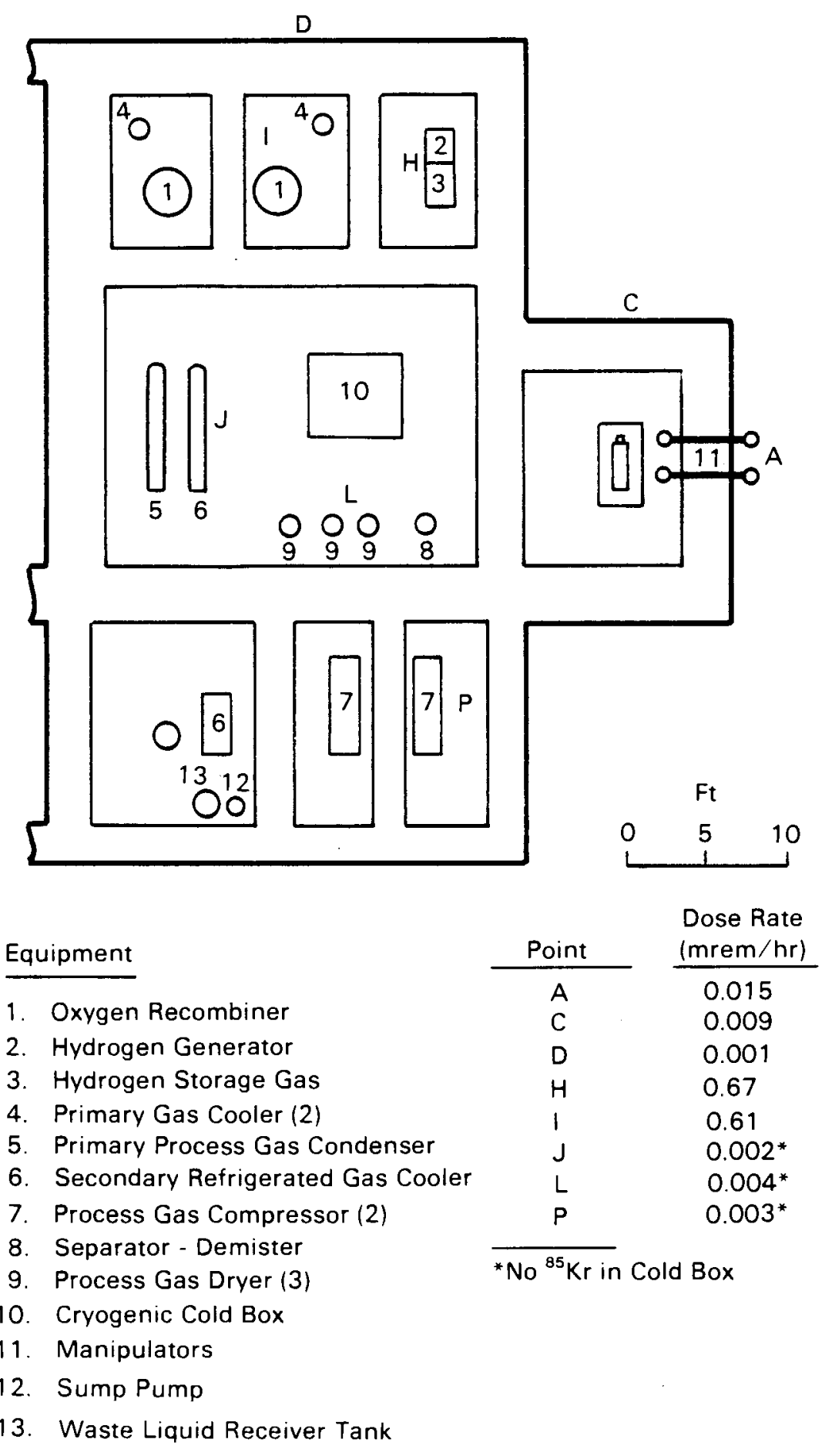

FIGURE 5.1. Calculated Dose Equivalent Rates Inside the Cryogenic Distillation Krypton Recovery Facility 
IABLE 5.1. Maintenance Requirements for Cryogenic Distillation Facility

\begin{tabular}{|c|c|c|}
\hline Equipment & Number & $\begin{array}{l}\text { Man-hr/yr per } \\
\text { Piece of Equiement (a }\end{array}$ \\
\hline Valves & 91 & 1 \\
\hline Crane & 1 & 100 \\
\hline Primary process condenser & 1 & 70 \\
\hline Secondary process condenser & 1 & 70 \\
\hline Demister & 1 & 15 \\
\hline Process gas dryer & 3 & 150 \\
\hline \multicolumn{3}{|l|}{ Cryogenic cold box } \\
\hline columns & 5 & 40 \\
\hline receivers & 2 & 15 \\
\hline valves & 20 & 1 \\
\hline electric heaters & 9 & 4 \\
\hline Oxygen recombiner & 1 & 0.5 \\
\hline $\begin{array}{l}\text { Hydrogen generator and } \\
\text { gas holder }\end{array}$ & 1 & $52^{(b)}$ \\
\hline Recycle gas cooler & 2 & 70 \\
\hline Process gas compressor & 2 & 70 \\
\hline Refrigeration unit & 1 & 100 \\
\hline $\begin{array}{l}\text { Diesel engine and } \\
\text { electric generator }\end{array}$ & 1 & $170^{(b)}$ \\
\hline Manipulators & 6 & 280 \\
\hline Total System man-hrs/yr & & $3364^{(c)}$ \\
\hline
\end{tabular}

\footnotetext{
(a) This maintenance time must be multiplied by two (unless otherwise noted) because the work will be done in a radiation zone.

(b) This equipment is outside a radiation zone.

(c) Divide by 2000 man-hr/yr/person to estimate persons required, i.e., $3364 \div 2000=1.7 \mathrm{man}-\mathrm{yr} / \mathrm{yr}$.
}

Table 5.2. Details of this analysis can be found in PNL-3176 (Mellinger et al. 1980). For our purposes, the first case, one-inch $\mathrm{Pb}$ on cold box, results in an excessive dose rate and is therefore not considered further. 
IABLE 5.2. Occupational Exposure for Cryogenic Distillation Fac1lity (man-rem/yr)

\begin{tabular}{lccc}
\multicolumn{1}{c}{ Case } & Operational & Maintenance & Total \\
\cline { 1 - 1 } $\begin{array}{l}\text { One-inch Pb } \\
\text { on cold box }\end{array}$ & 0.01 & 467 & 467 \\
$\begin{array}{l}\text { Two-inch Pb } \\
\text { on cold box }\end{array}$ & 0.01 & & 2.2 \\
$\begin{array}{l}\text { Three-inch Pb } \\
\text { on cold box }\end{array}$ & 0.01 & & 0.29 \\
$\begin{array}{l}\text { Cold box system purge } \\
\text { for maintenance }\end{array}$ & 0.01 & 0.29 & 0.28
\end{tabular}

\subsection{2 eccupational Doses from Fluorocarbon Absorption Facility}

The fluorocarbon absorption process and facil ity have been described in Section 3.4. It is a continuous process, and, compared to the cryogenic distillation process, very 1 ittle ${ }^{85} \mathrm{Kr}$ is concentrated in the process vessels at one time. Only moderate amounts of shielding are required for the cold traps where the ${ }^{85} \mathrm{Kr}$ is concentrated, and $1-1 / 2$ inches of lead shielding are adequate to reduce the dose equivalent rate to below the design guide of $1 \mathrm{mrem} / \mathrm{hr}$.

A1 1 the process equipment can be fitted into the same 6-m-by-9-m process cell used for the cryogenic distillation process. A detailed 1 ist of equipment and a process flow diagram is given by Waggoner (1982). No details of the physical 1 ayout of the fluorocarbon absorption system are given, so the authors used the equipment 1 isted by Waggoner and devised the 1 ayout shown in Figure 5.2. In this scheme, the equipment containing the most ${ }^{85} \mathrm{Kr}$ (the krypton column and the cold traps) is $\mathrm{placed}$ at one end of the process cel 1 , and the equipment requiring the most maintenance is placed at the opposite end. A1so, 0.6-m to $1.2-\mathrm{m}$ spacing is maintained between each major piece of equipment for ease of maintenance. This 1 ayout minimizes radiation exposure, and workers can enter the process cell to perform routine maintenance while the equipment is operating. However, this may not be the way an operating plant is designed. 


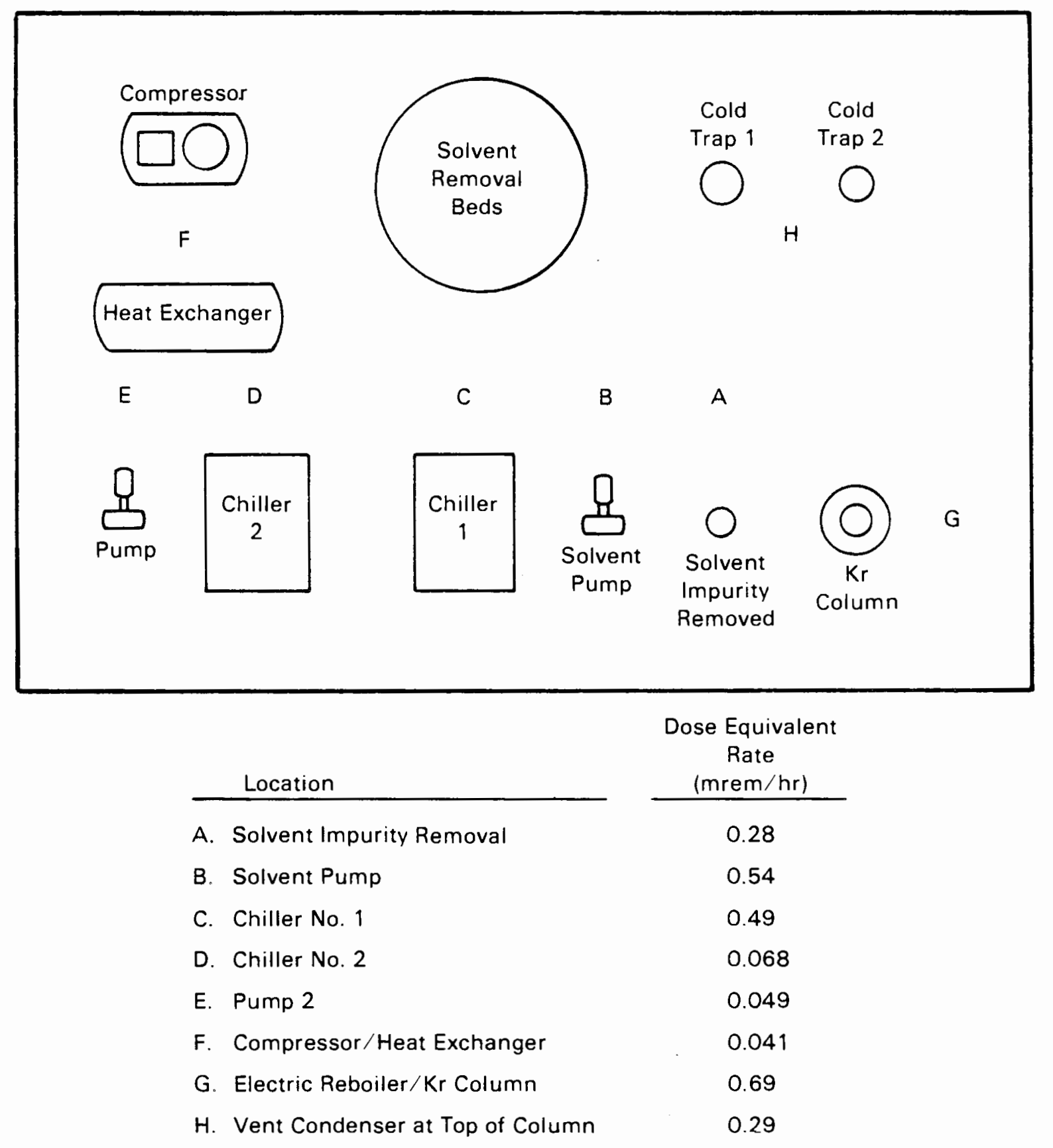

FIGURE 5.2. Dose Rates in Fluorocarbon Absorption Cell Near Various Pieces of Equipment 
A modified version of the computer code PERCS (Reece et a1. 1984) was used to calculate the dose equivalent rates from the ${ }^{85} \mathrm{Kr}$ in the process ce 1 1, assuming that $3.5 \mathrm{Ci}$ of ${ }^{85} \mathrm{Kr}$ are contained in the krypton column, $110 \mathrm{Ci}$ are in Cold Trap Number 1 and $950 \mathrm{Ci}$ are in Cold Trap Number 2, as calculated from the mass flow rates and vessel sizes (Waggoner 1982). These inventories are representative of processing 30-year-old nuclear fuel where the ${ }^{85} \mathrm{Kr}$ content is only $0.86 \%$ of the total krypton content. Both cold traps are assumed to have $3.8 \mathrm{~cm}$ of lead shielding, as suggested previously (Waggoner 1982).

\subsubsection{Operational Doses}

Assuming the process cell walls (Figure 33 ) are $30 \mathrm{~cm}$ of concrete, the dose equivalent rates outside the process cell walls are calculated to be less than $0.005 \mathrm{mrem} / \mathrm{hr}$ from the ${ }^{85} \mathrm{Kr}$ inside the process cell. Since the process is designed to be remote and continuous, no one needs to enter the process cel1 during normal operations. Therefore, the operational doses are assumed to be negligible for normal operations.

\subsubsection{Maintenance Doses}

During routine operation of the fluorocarbon absorption process, the equipment does require periodic maintenance. The ma intenance requirements for the equipment in the fluorocarbon absorption process cell are shown in Table 5.3. These estimates, based on previous studies (Mellinger et al. 1980), are time estimates for "generic" pieces of equipment; a particular piece of equipment could require more or less maintenance than shown here.

A modified version of the computer code PERCS (Reece et a 1. 1984) was used to calculate the dose equivalent rates near each of the major pieces of equipment (Figure 5.2). These dose rates were calculated at a height of 4 feet above the floor (chest height). For the calculations it was assumed that the krypton column was operated in a continuous recycle mode and that both cold traps contained $85 \mathrm{Kr}$. However, for work on the cold traps or on the nearby valves, it was assumed the krypton was vented and the cold traps were purged so that only the $85 \mathrm{Kr}$ in the krypton column contributed to exposure. Also, it was assumed that each piece of equipment is isolated 
IABLE 5.3. Maintenance Requirements and Integrated Doses for Fluorocarbon Absorption System

\section{Equipment}

Feed Gas Compressor

Heat Exchanger

Vent Condenser

Krypton Column

Electric Reboiler ( $1 \mathrm{~kW}$ )

Solvent Removal Bed ( $6 \mathrm{ft}$ dia $\times 2 \mathrm{ft}$ )

Solvent Removal Bed ( $1 \mathrm{ft}$ dia $\times 2 \mathrm{ft}$ )

Impurities Removal Bed ( $1 \mathrm{ft}$ dia $\times 2 \mathrm{ft}$ )

$\mathrm{CO}_{2}$ Removal Bed (6 in dia $\times 1 \mathrm{ft}$ )

Cold Trap No. 1

(1.5 ft dia $\times 2 \mathrm{ft}, 1.5$ in $\mathrm{Pb}$ )

Cold Trap No. 2

( $1 \mathrm{ft}$ dia $\times 2 \mathrm{ft}, 1.5$ in $\mathrm{Pb}$ )

2 Chillers (to $-35^{\circ} \mathrm{C}$ )

14 Valves

2 Pumps
Man-hours/year Integrated Dose Per Piece of Equipment

70

15

15

40

4

$15^{(a)}$

$15^{(a)}$

$15^{(a)}$

$15^{(a)}$

$15^{(\mathrm{a})}$

$15^{(a)}$

70

1

80

$550^{(b)}$ (man-rem $/ y r)$

0.0029

0.0006

0.0044

0.028

0.0028
0.0044

0.0044

0.0046

0.039

0.0049

0.047

0.16

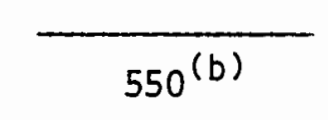

$\frac{0.047}{0.16}$

\section{Total System}

(a) Assumed to require the same maintenance as process gas receiver in cryogenic separation process.

(b) Divide by $2000 \mathrm{man}-\mathrm{hr} / \mathrm{yr} / \mathrm{person}$ to estimate persons

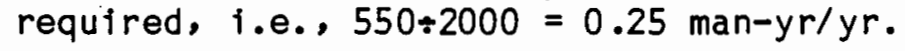

and purged of $85 \mathrm{Kr}$ before it is worked on, so there would be almost no inhalation dose when the equipment is disassembled.

Using these calculated dose equivalent rates and the annual maintenance time required for each piece of equipment, the occupational doses associated with equipment maintenance were calculated. As shown in Table 53, no single item predominates, and the total occupational dose for each year of operation is on 1 y 0.16 man-rem. This could be considerably higher 
if the cold traps are not purged of krypton before workers perform maintenance on the traps or nearby valves. The dose equivalent rate near the cold traps is only $0.15 \mathrm{mrem} / \mathrm{hr}$ with the $85 \mathrm{Kr}$ purged; with $85_{\mathrm{Kr}}$ in the cold traps the dose equivalent rate can be tens of $\mathrm{mrem} / \mathrm{hr}$. Also, if the equipment requiring the most maintenance (compressors, pumps, chillers) were located closer to the cold traps and krypton column, the integrated doses would be much higher. For example, if they were located within $1.2 \mathrm{~m}$ of the krypton column on cold traps, the integrated dose for maintenance could be as high as $0.10 \mathrm{man}-\mathrm{rem} / \mathrm{yr}$ for these items alone.

\subsubsection{Occupational Doses from an Ion Implantation/Sputtering Facility}

The ion implantation/sputtering process and facility have been described in detail in Section 3.4. This section deals with the occupational doses arising from the operation of the reference ${ }^{85} \mathrm{Kr}$ implantation facility. Estimated manpower requirements for operating the facility are representative of those shown in Table 3.6.

The radiation dose rates at various locations in the facility where personnel will be exposed (capital letters in Figure 53) have been calculated (Table 5.4) using a slightly modified version of the computer code PERCS (Reece et a1. 1984), and ISOSHLD (Engel et a 1. 1966 and Simmons et a 1. 1967) for gammas and bremsstrahlung contribution, respectively. The contribution from bremsstrahlung is only important for 1 ightly shielded sources; the low energy photons do not penetrate the massive shields used in the ${ }^{85} \mathrm{Kr}$ encapsulation faclitity. The computer codes PERCS and ISOSHLD calculated similar dose rates for the heavily shielded ${ }^{85} \mathrm{Kr}$ sources (behind concrete or 1ead). Because PERCS is much easier to use, it was used for most of the dose rate calculations.

As noted in the section describing the ion implantation/sputtering facility, adequate shielding was not provided in the preconceptual reference design, so the PERCS code was used to calculate additional shielding requirements. Areas that required additional shielding were the sputtering stations, the canister welding and inspection stations $(5 \mathrm{~cm}$ of lead shielding added), and the canister storage $(61 \mathrm{~cm}$ of concrete). Minimal 


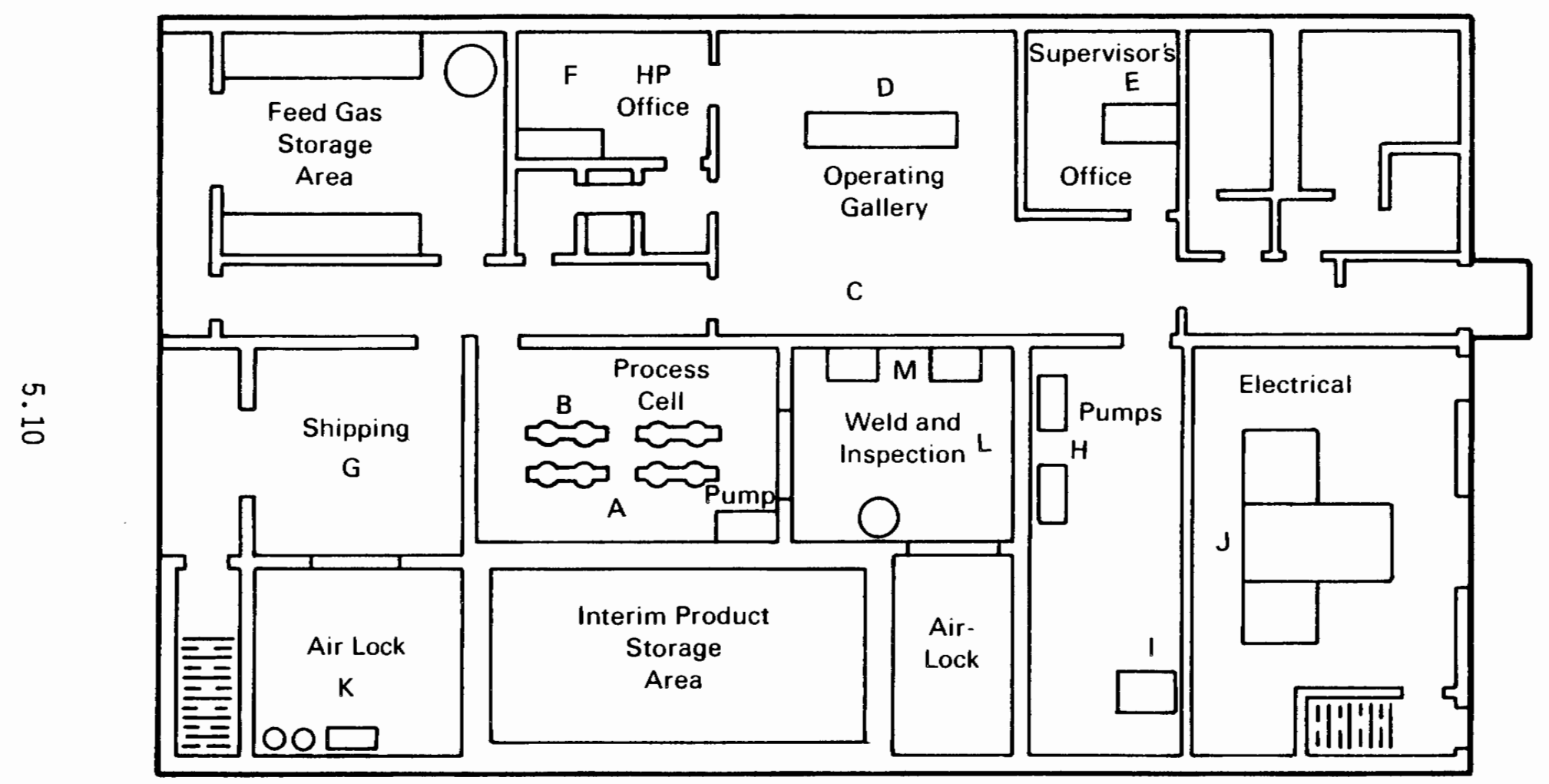

FIGURE 5.3. Locations Where Dose Equivalent Rates are Calculated for Ion Implantation/Sputtering Facility

(See Table 5.5 for doses) 
IABLE 5.4. Calculated Dose Equivalent Rates at Various Locations Inside the Ion Implantation/Sputtering Facility

\begin{tabular}{|c|c|c|}
\hline Lecation & Description & $\begin{array}{l}\text { Dose Equivalent Rate } \\
\text { (mrem/hour) }\end{array}$ \\
\hline A & Process ce 11 near product storage & 1.5 \\
\hline B & Process cell near sputtering apparatus & 1.6 \\
\hline C & Canister welding in operating gallery & 0.06 \\
\hline D & Operating gallery console & 0.1 \\
\hline$E$ & Supervisor's office & 0.0004 \\
\hline $\mathrm{F}$ & Health physics office & 0.1 \\
\hline G & Shipping & 0.5 \\
\hline H & Pumps & 0.09 \\
\hline I & Pumps & 0.01 \\
\hline $\mathrm{J}$ & Electrical equipment & 0.001 \\
\hline k & Compressor in air lock & $3.5^{(a)}$ \\
\hline L & Bridge crane & 0.1 \\
\hline M & Between welder and leak detector & 0.9 \\
\hline
\end{tabular}

(a) It is assumed that the compressor should not be located outside the seismically reinforced structure; i.e., it should be bounded by $30-\mathrm{cm}-$ thick walls.

shielding was added so that the facility could be 1 icensed without extensive changes in the design or layout.

The two main sources of exposure to workers in the facility will be examined in deta 11: direct exposure to radiation from $85 \mathrm{Kr}$ in the factlity during normal operations and exposure during routine maintenance or repair on equipment in the facility.

\subsubsection{Occupational Doses from Normal Operations}

The operational doses received in processing the $85 \mathrm{Kr}$ are summarized in Table 5.5. Four persons are in low-level radiation fields while in the building for 2000 working hours per year and while in the sputtering cel 1 to set up and remove target/substrate assemb 1 ies for immobilizing ${ }^{85} \mathrm{Kr}$. A significant contribution comes from preparing canisters for shipment where 
IABLE 5.5. Operational Doses from Handling and Processing $85_{\mathrm{Kr}}$ in the Ion Implantation/Sputtering Facility

Annua 1

Integrated Dose

Source of Exposure

$(\operatorname{man}-r e m / y r)$

General building background

0.31

Radiation surveys

0.30

Entry into process cell to set up

0.10 sputtering assembly and stations

welding on lids and inspecting

$0.20^{(a)}$ canisters for leaks

Preparing canisters for shipment

0.27

Total

$1.2 \mathrm{man}-\mathrm{rem} / \mathrm{yr}$

(a) Assumes no lead shielding around canister during welding operation; this value is reduced to $0.02 \mathrm{man}-\mathrm{rem} / \mathrm{yr}$ with addition of $5 \mathrm{~cm}$ of lead shielding.

personnel are in high radiation areas to load, inspect, and survey the shipping containers for shipment to a permanent storage facility, assumed to be a retrievable surface storage facility or a geologic repository. This dose is significant because two persons must come in close proximity to each canister in the shipping container to verify radiation levels and the integrity of the shipping container. One of these persons is the health physics technician who also has other functions to perform in this facility. It is assumed that radiation surveys are performed whenever a worker enters a radiation zone for normal operation or for maintenance as well as routine surveys around the facility. The total integrated dose for normal operations is estimated to be about 1.2 man-rem per year of operation. This could be reduced considerably by redesigning the facility to include more shielding and remote operations, but the maintenance doses would then increase. 


\subsubsection{Qccupational Doses from Equipment Ma intenance}

A significant occupational dose is received by workers who service and maintain the equipment in the facility. A complete list of all the equipment in the facility is given in a document prepared by The Ralph $M$. Parsons Company (RMP 1981). Table 5.6 summarizes the most important pieces of equipment and 7 ists estimated maintenance times that are taken from previous studies (Mellinger et al. 1980). Using these estimated times and the radiation dose rates calculated at various locations by the computer code PERCS, the radiation doses involved in equipment maintenance in the facility during normal operation are estimated. None of these integrated doses are excessive, even though some of the equipment is located in potentially high radiation fields. Care must be taken in designing the shielding around the feed gas compressors to avoid excessively high dose rates in the 1 ag storage area. A problem might also arise from entrainment of $85 \mathrm{Kr}$ in the vacuum 1 ines. The location of the equipment is shown in Figure 5.3. The total integrated dose for normal contact maintenance operations was about 1.4 man-rem per year. Depending upon the location of the vacuum pumps and where maintenance is performed, the calculated values range from 0.7 to $1.5 \mathrm{man}-\mathrm{rem} / \mathrm{yr}$. This could be considerably higher if problems developed in the interim product storage area. It would be necessary to

remove the ${ }^{85} \mathrm{Kr}$ to gain access to these high radiation areas. Another area that must be considered is the piping containing feed-gas. Unshielded pipe runs could result in very high dose rates. Although it is not shown in the preconceptual design, it would be a good idea to design a wel 1 shielded pipe gal lery.

\section{1 .4 Summary of Occupational Doses}

The total external integrated doses involved in the capture of ${ }^{85} \mathrm{Kr}$ each year can be determined by adding together the external doses from the cryogenic distillation facility or the fluorocarbon absorption facility with the external doses from ion implantation/sputtering facility. These doses are summarized in Table 5.7. Since the facility is operated over a 30-year period, these integrated doses can be multiplied by 30 to calculate the occupational dose over the 1 ifetime of the plant. 
IABLE 5,6. Maintenance Requirements and Occupational Doses from Equipment in Radiation Zones in the Ion Implantation/Sputtering Facility

\begin{tabular}{|c|c|c|c|}
\hline Equipment & Number & $\begin{array}{l}\text { Man-hours/year per } \\
\text { piece of equipment }\end{array}$ & $\begin{array}{l}\text { Integrated Dose } \\
\text { (man-rem/yr) }\end{array}$ \\
\hline Feed gas compressor & 1 & 70 & 0.24 \\
\hline $\begin{array}{l}\text { Vacuum pumps for } \\
\text { sputtering chambers }\end{array}$ & 2 & 60 & 0.18 \\
\hline Other pumps in facility & - & -- & 0.016 \\
\hline Pressurized feed gas filter & 1 & unknown & -- \\
\hline $\begin{array}{l}\text { Sputtering heads and } \\
\text { shielded cooling jackets }\end{array}$ & 8 & 20 & 0.24 \\
\hline $\begin{array}{l}\text { Mini-trailer robo-carrier or } \\
\text { remote stacker/retriever }\end{array}$ & 2 & 100 & 0.16 \\
\hline In cell bridge crane & 1 & 100 & 0.01 \\
\hline $\begin{array}{l}\text { Remote welder in cell } \\
\text { (replace with spare) }\end{array}$ & 1 & 10 & 0.009 \\
\hline $\begin{array}{l}\text { Helium leak detection } \\
\text { (replace with spare) }\end{array}$ & 1 & 10 & \\
\hline Master-slave manipulators & 4 & 280 & 0.38 \\
\hline $\begin{array}{l}\text { Valves in process } 7 \text { ines and } \\
\text { radiation zones }\end{array}$ & 122 & 1 & 0.12 \\
\hline Total System & & $1912^{(a)}$ & 1.36 \\
\hline
\end{tabular}

(a) Divide by $2000 \mathrm{man}-\mathrm{hr} / \mathrm{yr} / \mathrm{person}$ to estimate persons required, $1912 \div 2000=0.96$ 
IABLE 5.7. Summary of Operational and Contact Majintenance Doses for Each Year of Operation of $85 \mathrm{Kr}$ Separation and Encapsulation Facilities

\begin{tabular}{|c|c|c|c|}
\hline & \multicolumn{3}{|c|}{ Integrated Dose (man-rem/yr) } \\
\hline & Operational & Maintenance & Total \\
\hline $\begin{array}{l}\text { Cryogenic Distillation } \\
\text { recovery facility }\end{array}$ & 0.01 & 2.2 to 0.27 & 2.2 to 0.28 \\
\hline $\begin{array}{l}\text { Fluorocarbon Absorption } \\
\text { recovery facility }\end{array}$ & sma 11 & 0.16 & 0.16 \\
\hline $\begin{array}{l}\text { Ion Implantation/Sputtering } \\
\text { encapsulation facility }\end{array}$ & 1.2 & 1.4 & 2.6 \\
\hline Total (Cryogenic + Ion) & 1.2 & 3.6 to 1.8 & 4.8 to 3.0 \\
\hline Total (Absorption + Ion) & 1.2 & 1.6 & 2.8 \\
\hline
\end{tabular}

\subsection{PUBLIC EXPOSURE TO $85 \mathrm{Kr}$ RELEASED ROUTINELY FROM THE BNFP}

When ${ }^{85} \mathrm{Kr}$ is routinely released to the atmosphere directly from the DOG, the occupational workforce is not generally subjected to its radioactivity in the workplace. However, members of the workforce are exposed about 16 hours a day and the surrounding population is exposed full-time to the ${ }^{85} \mathrm{Kr}$ released to the environment. Therefore, the total release scenario (no recovery) is used to calculate doses for the maximum individual and the 50-mile regional population. The dosimetry of ${ }^{85} \mathrm{Kr}$ has been presented elsewhere (Mellinger et al. 1980). Equations used for these dose calculations are presented in Appendix B.

\subsubsection{Maximum Individual Dose}

The maximum ground-level concentration of ${ }^{85} \mathrm{Kr}$ occurred $1-2$ miles east of the site. The 30-year collective radiation dose commitment to a hypothetical individual continually located at this point during continuous routine release was about $0.7 \mathrm{mrem}$ to the total body, $1.3 \mathrm{mrem}$ to the lung, (a) and about $50 \mathrm{mrem}$ to the skin.

(a) Inhalation dose plus total-body dose. 
For ${ }^{85} \mathrm{Kr}$ with relatively 1 ittle penetrating (gamma) radiation, the critical organ will be the skin, even considering its less restrictive dose standard. However, where col lective doses are calculated, the total-body dose is preferred for estimating health effects.

The annual dose rate to the total body of the maximum individual was about 0.02 mrem. Proposed revisions of 10 CFR $20^{(a)}$ include lower (de minimis) limits, below which radiation dose levels need not be considered in dose assessments. The de minimis limit proposed for individuals is $1 \mathrm{mrem} / \mathrm{yr}$. Krypton-85 doses cannot be compared solely to the $1 \mathrm{mrem} / \mathrm{yr}$ because both tritium and ${ }^{14} \mathrm{C}$, also released by an FRP, would deliver larger radiation doses than $85 \mathrm{Kr}$. However, this quantification of a de minimis dose is a step in the right direction.

\subsubsection{Population Dose}

The population values used in this calculation (Table 4.1) are estimates for the year $2005 .^{(b)}$ The annual average meteorological dispersion factors presented in Table 4.2 are used as shown in Appendix $C$ to estimate radiation doses to the public.

The population is distributed relatively evenly beyond the influence of the DOE SRP site. The largest single population center within the 50mile radius of the BNFP is Augusta, Georgia, located about 35 miles WNW.

The 30-year cumulative 50-mile population dose commitment was about 70 man-rem. The annual population dose was calculated for the 50-mile population $(850,000$ people) to be about $2.35 \mathrm{man}-\mathrm{rem} / \mathrm{yr}$. This averages out to be a per-capita dose of about $0.003 \mathrm{mrem} / \mathrm{yr}$. The proposed revisions of 10 CFR 20 include lower 1 imits of col lective doses to individual members of a general population of $0.1 \mathrm{mrem} / \mathrm{yr}$. However, again, these are not directly comparable.

(a) An NRC proposed draft for changes in 10 CFR 20-(Subpart E De Minimis Levels for doses to Individual Members of the Public) September 26, 1983.

(b) Boone, F. W. 1982. Allied-Genera1 Nuclear Services, Memorandum to Files, "Update of Gaseous Effluent-Dose Commitment Analysis Documentation," ENV C.1, SEC/81/205, Rev 1, January 21. 


\subsubsection{Summary of Estimated Qccupational Doses ys. Public Radiation Doses}

It has been shown in Table 5.8 that if $85 \mathrm{Kr}$ is captured by cryogenic distillation and immobilized by ion implantation/sputtering, the annual average man-hours requires 7 men ful1-time or more than 7 men parttime. We assume a range of 7-9 men for cryogenic distillation and ion implantation/sputtering and 5-7 men for fluorocarbon absorption and ion implantation/sputtering. The average annual per-capita dose to the 7-9 exposed workers was estimated to be about 570-450 mrem (4 man-rem/yr $\div 7$ men). If fluorocarbon absorption is used instead of cryogenic distillation, the average annual per-capita dose to the 5-7 workers was estimated to be about 600-425 mrem (3 man-rem/yr $\div 5 \mathrm{men}$ ).

Comparing the average occupational exposures of the two recovery options coupled to ion implantation/sputtering and immobilization (about $3.5 \mathrm{man}-\mathrm{rem} / \mathrm{yr}$ ) with the 50-mile population dose (2.3 man-rem/yr), the dose commitment to the occupationa $11 y$ exposed workforce was not significantly higher than for the public. However, the annual average per capita dose to

TABLE 5.8. Comparison of Whole-Body Radiation Dose Rates from Two Krypton Removal Technologies with Ion Implantation Versus, Public Exposure from Routine Release to the Environment ${ }^{\text {(a) }}$

Average Individual Man-rem/yr Man-yr/yr Men mrem/yr

${ }^{85} \mathrm{Kr}$ Recovery and Immobilization

$\begin{array}{lllll}\text { Cryogenic + Ion } & 4 & 7 & 7-9 & 570-450 \\ \text { Absorption + Ion } & 3 & 5 & 5-7 & 600-420\end{array}$

Routine Iotal ${ }^{85} \mathrm{Kr}$ Release

$\begin{array}{llrrr}\text { Maximum Individual } & 0.00002 & - & 1 & 0.02 \\ 50-m i l e ~ P o p u l a t i o n & 2.4 & -- & 850,000 & 0.003\end{array}$

(a) This comparison is based on the release of $3 \times 10^{6} \mathrm{Ci} 85^{\mathrm{Kr}}$ during processing of $1500 \mathrm{t} / \mathrm{yr}$ of $30-\mathrm{yr}$ aged fue 1 . 
the occupationally exposed individual was about a factor of $1.7 \times 10^{5}$ greater than to an individual member of the public (500 mrem vs. $0.003 \mathrm{mrem})$. In addition, as noted in Chapter 3, only $95 \%$ of the ${ }^{85} \mathrm{Kr}$ is assumed to be recovered. Therefore, in the recovery case, a small dose is also delivered to the public from the $5 \% 85 \mathrm{Kr}$ still released to the environment, and dose is also delivered to workers from any onsite transport of waste containers that may occur. These doses tend to balance out and are not considered further. Therefore, there appears to be a possibility of increasing human health effects if ${ }^{85} \mathrm{Kr}$ is captured, concentrated, and stored rather than routinely released to the environment. 


\title{
6.0 HUMAN HEALTH EFFECTS
}

Health effects 1 ikely to result from exposure to low levels of ionizing radiation have been discussed in the BEIR III (Biological Effects of Ionizing Radiation) issued by the National Academy of Sciences (NAS 1980). Cancer mortality due to radiation exposure was reviewed, and a model for quantifying risks was developed. Problems that were encountered in relating estimates of risks due to exposure to low levels of radiation are discussed in detail throughout the report, and are briefly summarized below (BEIR III, PP. 142-143).

\begin{abstract}
"The quantitative estimation of the carcinogenic risk of lowdose, low-LET ( 1 inear energy transfer) radiation is subject to numerous uncertainties. The greatest of these concerns the shape of the dose-response curve. Others pertain to the length of the latent period, the relative biological effectiveness (RBE) for fast neutrons and alpha radiation relative to gamma and $x$ radiation, the period during which the radiation risk is expressed, the model used in projecting risk beyond the period of observation, the effect of dose rate or dose fractionation, and the influence of differences in the natural incidence of specific forms of cancer. In addition, uncertainties are introduced by the characteristics of the human experience drawn on for the basic risk factors, e.g., the effect of age at irradiation, the influence of any disease for which the radiation was given therapeutical1y, and the influence of length of follow-up."
\end{abstract}

One of the more severe problems is that in populations where the dose and exposure rates are $10 w$, extremely large sample sizes are required to reliably quantify the magnitude of effects. In the judgment of the BEIR III committee, none of the studies of human populations that have been exposed primarily at low levels provide sufficient information for risk estimation. Thus, it is necessary to extrapolate from estimates based on data from populations which include persons exposed at relatively high doses and dose rates such as the Japanese atomic bomb survivors and British ankylosing spondy 1 itis patients who were medically treated with radiation.

A1though estimates of risks due to radiation have often been based on a 1 inear extrapolation model (NAS 1972; UNSCEAR 1977; ICRP 1977), the BEIR III committee adopted a 1 inear-quadratic function as providing the most 
plausible description of the dose-response relationship in the low-tointermediate range. BEIR III also provided alternative estimates based on the 1 inear and pure quadratic models. The use of a model (such as the 1 inear-quadratic) that provides for a reduction in 1 inear effects with 1 ow Linear Energy Transfer (LET) radiation for reduced doses and dose rates can be justified based on evidence that is summarized in a report of the Nationa 1 Council 1 on Radiation Protection and Measurements (NCRP 1980). In this report it is stated that it is clear from the data obtained from al 1 endpoints examined, from cell death to tumor induction, that a reduction in dose rate in general results in a reduced biological effect.

Another difficulty in obtaining 7 ifetime risk estimates is that none of the populations on which estimates of effects are based have yet been fol lowed to the end of their 1 ifespans. Two approaches were used by the BEIR III committee to extend risk estimates beyond the period represented by follow-up data. With the absolute risk model, it is assumed that the number of excess cases per unit of population per unit of time and per unit of radiation dose remains constant over a specified time period. With the relative risk model, it is assumed that the ratio of the excess cancer risk to the spontaneous age-specific risk remains constant over the specified period. Since spontaneous rates generally increase with age, the relative risk model will yield 1 arger numbers for the years beyond the fol $10 w-u p$ period. The most recent data on Japanese survivors (Kato and Schu1 1 1982) as wel 1 as data on British ankylosing spondylitis patients (Smith and Dol 1 1982) indicate that the relative risk projection model is probably more appropriate than the absolute model.

We compared estimates of cancer mortality based on the results presented in the last two columns of Table 5.8. For this purpose, we used 


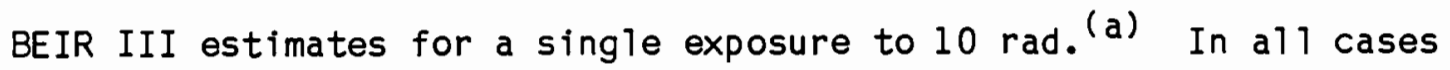
examined in this study, dose rates are lower than those considered by BEIR III, especially the situation involving total ${ }^{85} \mathrm{Kr}$ release to the environment. To obtain estimates for the number of cancers expected in each of these situations we have reduced the BEIR III 10-rad estimates of risk in proportion to the estimated ${ }^{85} \mathrm{Kr}$ dose, and then multiplied by the number of individuals at risk to obtain the expected number of cancer deaths induced by the radiation received in a single year of plant operation. These estimates are then multiplied by 30 and the exposed population to obtain estimates of the total cancer mortality expected to result from 30 years of plant operation as presented in Table 6.1. Estimates based on several models are presented in BEIR III, but here we consider only the estimates based on the 1 inear-quadratic relative risk model ${ }^{(b)}\left(2255\right.$ deaths $/ 10^{6}$ people/yr for a 10-rad dose) as summarized in Table V-22 (BEIR III, p. 209). As noted above, this estimate can probably be considered as the most plausible of the estimates given. It is emphasized that although the linear-quadratic model provides for reduced effects (per rad) for exposures

(a) BEIR III also provides estimates of the effects of exposures of one rad per year either persisting throughout a lifetime or for various ages intended to reflect occupational exposures. These alternative estimates have not been used, because they are based on the assumption that all persons at risk receive exposure from birth to the end of 1 ife (or from particular specified ages in the case of occupational exposure). In the situation of interest in this report, it is expected that persons will begin exposure at different ages, and that as persons move away or leave their jobs, others will replace them. With the 1 inear-quadratic function used in BEIR III, the effect (per rad) of $10 \mathrm{rad}$ is not that much different than the effect of one rad. The slight per-rad increase resulting from using the 10-rad situation as opposed to using the single-rad exposure situation will be the same for either situation (e.g., capture vs. release) being compared in this study.

(b) Although the magnitude of the risks predicted by other BEIR III models would differ from those given in this report, the ratios of the estimates for the three exposure situations examined here would be the same, and thus the comparison of these estimates is unaffected by the choice between linear and linear-quadratic models and between absolute and relative risk models. 


\section{IABLE 6.1. Comparison of Estimated Cancer Mortality from the Capture and Immobilization of ${ }^{85} \mathrm{Kr}$ as Opposed to Routine Release to the Environment}

Exposure Situation

Lifetime Risk/Person Der Year Exposure
Total Number of Radiation-Induced Cancer Deaths Expected from 30 Years of Exposure

Occupational (Capture)

$\begin{array}{lll}450 \mathrm{mrem} / \mathrm{yr} & 1.0 \times 10^{-4} & 0.027 \\ 9 \mathrm{people} & & \\ 570 \mathrm{mrem} / \mathrm{yr} & 1.3 \times 10^{-4} & 0.027 \\ 7 \mathrm{people} & & 0.020 \\ 425 \mathrm{mrem} / \mathrm{yr} & \\ 7 \mathrm{people} & 9.6 \times 10^{-5} & 0.020 \\ 600 \mathrm{mrem} / \mathrm{yr} & 1.4 \times 10^{-4} & \\ 5 \mathrm{people} & & \\ \text { eneral Public (Routine Release) } & 0.017 \\ 0.003 \mathrm{mrem} / \mathrm{yr} & 6.8 \times 10^{-10} & \\ 850,000 \mathrm{people} & & \end{array}$

(a) 2255 deaths $/ 10^{6}$ people/yr for 10 rad dose

at ten rad per year as opposed to exposure of 100 rads or more, it does not provide for reduced effects from the dose rates involved in ${ }^{85} \mathrm{Kr}$ release to the environment as opposed to the higher dose rates involved in occupational exposures.

It is emphasized that these estimates are based on the assumption that at the levels being compared, risks are proportional to dose. Data from animal experiments indicate that exposures at low dose rates (in the range of 10 rad per day) convey less risk (per rad) than do exposures at high dose rates (in the range of 50 rad per minute). Unfortunately, there are no adequate data to al low comparing effects of the 500-mrem year occupational dose to the $0.003-\mathrm{mrem} /$ year population dose developed in this study. It is possible that no risks would occur from either situation (e.g., capture vs. release). 
Given the uncertainties in the models used to generate these estimates, the differences in total risks for the situations considered here cannot be considered meaningful. Certainly there is no compel 1 ing reason to conclude that risks from ${ }^{85} \mathrm{Kr}$ release are greater than those from capturing and immobilizing $85 \mathrm{Kr}$. 


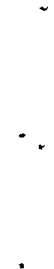




\subsection{REFERENCES}

AGNS. 1971. Barnwel1 Nuclear Fuel Plant - Environmental Report. NRC Docket No. 50-332, Al1 led-General Nuclear Services, Barnwe1 1, South Carolina.

AGNS. 1981. Away-From-Reactor Storage - Safety Analys is Report. AGNS47921-1.4-2, EINAL DRAFI, A1 1 ied-Genera 1 Nuclear Services, Barnwe1 1 , South Carol ina.

Afrco Cryoplants Inc. 1976. Cryogenic Gaseous Radwaste Separation Process for Nuclear Waste Gas Decontamination. GRASP-76-239, Murry Hi11, New Jersey.

Bayne, M. A., R. W. Moss and E. D. MCClanahan. 1978. Krypton Entrapment in Pulse Biased Sputter-Deposited Meta]s. PNL-SA-6698, Pacific Northwest Laboratory, Rich 1 and, Wash ington.

Be 1 1, M. J. 1973. QRIGEN - The ORNL Isotope Generation and Dep letion Code. ORNL-4628, Oak Ridge National Laboratory, Oak Ridge, Tennessee.

Bendixsen, C. L., and G. F. Offutt. 1969. Rare Gas Recovery Facflities at the Idaho Chemical Processing Plant. IN-1221, Idaho Nuclear Corp., Idaho Fal 1s, Idaho.

Brown, R. A., D. A. Knecht and T. R. Thomas. 1978. Reference Facility Description for the Recovery of Iodine, Carbon and Krypton from Gaseous Wastes. ICP-1126, Idaho Nationa 1 Engineering Laboratory, Idaho Fal 1s, Idaho.

DOE. 1979a. Draft Environmental Impact Statement - Management of Commercial Iy Generated Radioactive Waste. DOE/EIS-00 46-D, Washington, D.C.

DOE. 1979b. Technology for Commercial Radioactive Waste Management. DOE/ET-0028, Washington, D.C.

DOE. 1981. Spent Fuel Storage Requirements. DOE/SR-0007, Aiken, South Carolina.

DOE. 1982. U.S. Commercial Nuclear Power: Historical Perspective, Current Status, and Outlook. DOE/EIA-0315, Washington, D.C.

DOE. 1983. Spent Fuel Storage Reguirements. DOE/RL-83-1, Rich 1 and, Washington.

Enge 1, R. L., J. Greenborg and M. M. Hendrickson. 1966. ISQSHLD - A Computer Code for General Purpose Isotope Shielding Analysis. BNWL-236, Pacific Northwest Laboratory, Richland, Washington.

EPA. 1973. Environmental Analys is of the Uranium Fuel Cycle. Part III Nuclear Fuel Reprocessing. EPA-520/9-73-003-D, Washington, D.C.

EPA. 1975. Draft Environmental Statement for a Proposed Rulemaking Action for Action Concerning Environmental Radiation Protection Requirements for Normal Operations of Activities in the Uranium Fuel Cycle. Washington, D.C. 
EPA. 1976a. Environmental Radiation Protection for Nuclear Power Operations - Proposed Standards (40 CFR 190) - Supplementary Information. Washington, D.C.

EPA. 1976b. Final Environmental Statement - 40 CFR 190 - Environmental Radiation Protection Requirements for Normal Operations of Activities in the Uranium Fuel Cycle. EPA 520/4-76-016, EPA, Washington, D.C.

EPA. 1976c. Environmental Analysis of the Uranium Fuel Cycles Part IV Supplementary Analys is 1976. EPA 520/4-76-017, Washington, D.C.

EPA. 1977. Environmental Radiation Protection Standards for Nuclear Power operations. Federal Register 42(9), Title 40, Part 190. Washington, D.C.

ERDA. 1974. "General Design Criteria." ERDA Manual, Chapter 6301, Appendix Part II, Sect. I, "Plutonium Facilities," Washington, D.C.

Exxon Nuclear Company. 1977. Nuclear Fuel Recovery and Recycling Center Environmenta] Report. XN-FR-33, NRC Docket No. 50-564. Richland, Washington.

International Commission on Radiological Protection (ICRP). 1959. Recommendations of the International Commission on Radiological Protection. Report of Committee II on Permissible Dose for Interval Radiation. Pergamon Press, New York. New York.

International Commission on Radiological Protection (ICRP). 1977. Radiation Protection. ICRP 26, New York, New York.

Kato, H., and W. J. Schul 1. 1982. "Studies of the Mortality of A-Bomb Survivors 7. Mortality, 1950-1978: Part I. Cancer Mortal ity." Radiation Research $90: 395-432$.

Killough, G. G., and L. R. McKay. 1976. A Methodelegy for Calculating Radiation Doses from Radioactivity Released to the Environment. ORNL-4992, Oak Ridge National Laboratory, Oak Ridge, Tennessee.

Knecht, D. A. 1977. An Evaluation of Methods for Immobilizing Krypton-85. ICP-1125, Al lied Chemical Corporation, Idaho Fal Is, Idaho.

Mellinger, P. J., G. R. Hoenes, L. W. Brackenbush, and J. Greenborg. 1980. $85 \mathrm{Kr}$ Management Trade-0ffs: A Perspective to Total Radiation Dose Commitment. PNL-3176, Pacific Northwest Laboratory, Richland, Washington.

Merriman, J. R., M. J. Stephenson, B. E. Kanak, and D. K. Little. 1980. Removal of Noble Gases by Selective Absorption. IAEA-SM-245/53, Vienna, Austria.

NAS. 1972. The Effects on Populations of Exposure to Low Levels of Ionizing Radiation. (BEIR Report). Report of the Advisory Committee on the Biological Effects of Ionizing Radiation. National Academy of Sciences. National Research Council, Washington, D.C.

NAS. 1980. The Effects on Populations of Exposure to Low Levels of Ionizing Radiation. (BEIR III). Report of the Advisory Committee on the Biological Effects of Ionizing Radiation. National Academy of Sciences, National Research Counci1, Washington, D.C. 
NCRP. 1980. Influence of Dese and its Distribution in Time on Dose Response Relationships for Low-LET Radiations. NCRP Report No. 64, National Council on Radiation Protection and Measurements, Washington, D.C.

NRC. 1975. "Draft Environmental Statement Related to the Operation of the Barnwel 1 Fuel Receiving and Storage Station." Docket No. 70-1729, NUREG-75/026. Washington, D.C.

NRC. 1977. "Calculation of Annual Doses to Man from Routine Releases of Reactor Effluents for the Purpose of Evaluating Compliance with $10 \mathrm{CFR}$ Part 50, Appendix I." U.S. NRC Regulatory Guide 1.109, Rev. 1. Washington, D.C.

ORNL. 1970. Siting of Fuel Reprocessing and Waste Management Facilities. ORNL-445l, Oak Ridge National Laboratory, Oak Ridge, Tennessee.

Ralph M. Parsons Company (RMP). 1981. Krypton Encapsulation Preconceptual Design. Report No. 6154-3-1, prepared for the U.S. Department of Energy.

Reece, W. D., R. T. Hadley, R. Harty, J. G1 ass, J. E. Tanner and L. F. Munson. 1984. Personnel Exposure from Right Cylindrical Sources (PERCS): The Theory, the Code, and Examp les. NUREG/CR-3573 (PNL-4923), Pacific Northwest Laboratory, Richland, Washington.

Russe1 1, J. L., and F. L. Galpin. 1972. "Comparison of Techniques for Calculating Doses to the Whole Body and to the Lungs from Radioactive Nob 1e Gases." In: Radiation Protection Standards: Quo Vadis, Proceedings of the Sixth Annual Health Physics Society Topical symposium, pp. 286-308. Richland, Washington.

Schaeffer, R. 1973. "Calculs de Dose en Irradiation Extreme Par 1ex Gaz Ranes." Paper presented at the International Radiation Protection Association 3rd Congress, September 9-14, 1973, Washington, D.C., as referenced by Soldat et a 1. 1976.

Simmons, G. L., J. J. Regimba 1, J. Greenborg, E. L. Kel 1y, Jr., and H. H. VanTuy 1. 1967. ISQSHLD-II: Code Revision to Include Calculations of Dose Rate From Shielded Bremsstrah lung Sources. BNWL-236 Supplement 1. Pacific Northwest Laboratory, Richland, Washington.

Smith, P. G., and R. Dol1. 1982. "Mortal ity Among Patients with Ankylosing Spondy 1 itis After a Single Treatment Course with X-Rays." British Medical Journal 284:449-460.

Snyder, W. S., L. T. Dil 1 man, M. R. Ford and J. W. Poston. 1975. "Calculations of the Absorbed Dose to a Man Immersed in an. Infinite Cloud of Krypton-85." In: Noble Gases, The Proceedings of a Symposium held in Las Vegas, September 24-28, 1973. pp. 420-431.

Soldat, J. K., P. E. Bramson and H. M. Parker. 1976. The Dosimetry of the Radioactive Nob le Gases. BNWL-SA-4813, Rev. 2. Pacific Northwest Laboratory, Richland, Washington. 
Steiberg, M. 1959. The Recovery of Fission Product Xenon and Krypton by Absorption Processes. BNL-524, Brookhaven National Laboratory, Brookhaven, New York.

Strenge, D. L. and R. A. Peloquin. 1981. HADOC - A Computer Code for Calculation of External and Inhalation Doses From Acute Radionuclide Releases, PNL-3503. Pacific Northwest Laboratory, Richland, Washington.

Tingey, G. L., E. D. MCClanahan, M. A. Bayne and R. W. Moss. 1979. Entrapment of Krypton in Sputter Deposited Metals - A Storage Medium for Radioactive Gases. PNL-2879, Pacific Northwest Laboratory, Richland, Wash ington.

Trevorrow, L. E., V. M. Kolba, G. F. Vandegrift, and M. J. Steindler. 1983. Compatjbility of Technologies with Regulations in the Waste Management of ${ }^{3} \mathrm{H}_{2}{ }^{129} \mathrm{I},{ }^{14} \mathrm{C}$, and $85 \mathrm{Kr}$, Part II. Analysis. $\mathrm{ANL}-83-57$, Argonne National Laboratory, Argonne, I1 1 inois.

UNSCEAR. 1977. Sources and Effects of Ionizing Radiation. United Nations Scientific Committee on the Effects of Atomic Radiation, United Nations, New York.

Waggoner, R. C. 1982. Technical and Economic Evaluation of Processes for Kryoton-85 Recovery from Power Fuel Reprocessing Plant off-Gas. DP-1637, Savannah River Laboratory, Aiken, South Carolina.

Whitton, J. T. 1968. Dose Arising from Inhalation of Noble Gases. Central Electricity Generating Board, (CEGB), Report RD/B/N-1274, Berkeley Nuclear Laboratories, Berkeley, Glas. 
APPENDIX A

SOURCE-TERM SENSITIVITY ANALYSES 
APPENDIX A

$\frac{\text { SENSITIVITY ANALYSIS OF } 85 \mathrm{Kr} \text { RELEASES FROM AGED FUEL }}{\text { AS A FUNCTION OF THREE REPROCESSING SCENARIOS }}$

Most environmental assessments involving nuclear fuel reprocessing assume that the LWR fuel is about 160 or 180 days old at separation. However, the U.S. will probably not have any operational fuel reprocessing plants (FRP) before the year 2000. By that time there will be about 60,000 $t$ of spent fuel in storage. It is assumed here that oldest fuel will be reprocessed first. Therefore a U.S. FRP is not likely to reprocess fuel less than 30 years old.

Three reprocessing scenarios have been evaluated to 1) provide a more realistic estimate of the ${ }^{85} \mathrm{Kr}$ releases from an FRP separating aged fue 7 , and 2) explore the needed FRP capacity to separate the backlog of spent fuel within a reasonable time frame.

The decay algorithm, used to estimate the ${ }^{85} \mathrm{Kr}$ source term from decayed fuel, requires a decay time as input which is determined from the spent fuel data by subtracting the year that the spent fuel was produced from the year that the spent fuel is expected to be reprocessed. The decay algorithm uses only one decay time for each year of reprocessing and not for each year the fuel was produced, even though several years worth of fuel production may be reprocessed in the same year. If more than one year's production of spent fuel is reprocessed in one year, then the decay time of the newest spent fuel is used by the decay algorithm. This is conservative since some of the fuel reprocessed under this scenario has a longer decay time and, therefore, less radioactivity. Under this scenario, the decay algorithm actual $1 \mathrm{y}$ over-predicts the ${ }^{85} \mathrm{Kr}$ inventory.

The initial ${ }^{85} \mathrm{Kr}$ release from $1500 \mathrm{t}$ of reprocessed fuel is conservatively estimated to be about $3 \times 10^{6} \mathrm{Ci}$ as shown in Table A.l. This value is a reduction of about 5 the number of curies of ${ }^{85} \mathrm{Kr}$ contained in 180-daycooled fuel. 
TABLE A.1. Reprocessing Scenario A

\begin{tabular}{|c|c|c|c|c|c|c|c|}
\hline $\begin{array}{l}\text { END } \\
\text { OF }\end{array}$ & $\begin{array}{r}\text { FUEL } S \\
(M T\end{array}$ & $\begin{array}{l}\text { PPI.IED } \\
(H M)\end{array}$ & FUEL P & OCESSED & $\begin{array}{l}\text { NET } \\
\text { FUEL }\end{array}$ & $\begin{array}{l}\text { YEARLY KR85 } \\
\text { DISCHARGED }\end{array}$ & $\begin{array}{l}\text { ACCUM. KR } 8 \\
\text { DISCHARGED }\end{array}$ \\
\hline YEAR & ANNUAL & ACCUM & ANNUAL & $A C C U M$ & (MTIHM) & $(C I)$ & $(C I)$ \\
\hline 1971 & 124 & 124 & 0 & 0 & 124 & $0.00 E+00$ & $0.00 E+00$ \\
\hline 1972 & 201 & 415 & 0 & 0 & 415 & $0.00 E+00$ & $0.00 E+00$ \\
\hline 1973 & 165 & 580 & 0 & 0 & 580 & $0.00 E+00$ & $0.00 E+00$ \\
\hline 1974 & 447 & 1027 & 0 & 0 & 1027 & $0.00 E+00$ & $0.00 E+00$ \\
\hline 1975 & 563 & 1590 & 0 & 0 & 1590 & $0.00 E+00$ & $0.00 E+00$ \\
\hline 1976 & 682 & 2272 & 0 & 0 & 2272 & $0.00 E+00$ & $0.00 E+00$ \\
\hline 1977 & 860 & 3132 & 0 & 0 & 3132 & $0.00 E+00$ & $0.00 E+00$ \\
\hline 1978 & 1150 & 4282 & 0 & 0 & 4282 & $0.00 E+00$ & $0.00 E+00$ \\
\hline 1979 & 1204 & 5486 & 0 & 0 & 5486 & $0.00 E+00$ & $0.00 E+00$ \\
\hline 1980 & 1149 & 6635 & 0 & 0 & 6635 & $0.00 E+00$ & $0.00 E+00$ \\
\hline 1981 & 1265 & 7900 & 0 & 0 & 7900 & $0.00 E+00$ & $0.00 E+00$ \\
\hline 1982 & 1089 & 8989 & 0 & 0 & 8989 & $0.00 E+00$ & $0.00 E+00$ \\
\hline 1983 & 1300 & 10289 & 0 & 0 & 10289 & $0.00 E+00$ & $0.00 E+00$ \\
\hline 1984 & 1618 & 11907 & 0 & 0 & 11907 & $0.00 E+00$ & $0.00 E+00$ \\
\hline 1985 & 1905 & 13812 & 0 & 0 & 13812 & $0.00 E+00$ & $0.00 E+00$ \\
\hline 1986 & 2207 & 16019 & 0 & 0 & 16019 & $0.00 E+00$ & $0.00 E+00$ \\
\hline 1987 & 2493 & 18512 & 0 & 0 & 18512 & $0.00 E+00$ & $0.00 E+00$ \\
\hline 1988 & 2752 & 21264 & 0 & 0 & 21264 & $0.00 E+00$ & +00 \\
\hline 1989 & 2572 & 23836 & 0 & 0 & 23836 & $0.00 E+00$ & $0.00 E+00$ \\
\hline 1990 & 3238 & 27074 & 0 & 0 & 27074 & $0.00 E+00$ & $0.00 E+00$ \\
\hline 1991 & 2931 & 30005 & 0 & 0 & 30005 & $0.00 E+00$ & $0.00 E+00$ \\
\hline 1992 & 2886 & 32891 & 0 & 0 & 32891 & $0.00 E \div 00$ & $0.00 E+00$ \\
\hline 1993 & 3123 & 36014 & 0 & 0 & 36014 & $0.00 E+00$ & $0.00 E+00$ \\
\hline 1994 & 2993 & 39007 & 0 & 0 & 39007 & $0.00 E+00$ & $0.00 E+00$ \\
\hline 1995 & 2995 & 42002 & 0 & 0 & 42002 & $0.00 E+00$ & $0.00 E+00$ \\
\hline 1996 & 3208 & 45210 & 0 & 0 & 45210 & $0.00 E+00$ & $0.00 E+00$ \\
\hline 1997 & 3010 & 482 & 0 & 0 & 48220 & $0.00 E+00$ & $0.00 E+00$ \\
\hline 1998 & 3090 & 513 & 0 & 0 & 51310 & $0.00 E+00$ & $0.00 E+00$ \\
\hline 1999 & 3467 & 547 & 0 & 0 & 54777 & $0.00 E+00$ & $0.00 E+00$ \\
\hline 2000 & 3110 & 57887 & 0 & 0 & 57887 & $0.00 E+00$ & $0.00 E+00$ \\
\hline 2001 & 3027 & 60914 & 750 & 750 & 60164 & $1.34 \mathrm{E}+06$ & $1.34 E+06$ \\
\hline 2002 & 3618 & 64532 & 750 & 1500 & 63032 & $1.34 E+06$ & $2.68 E+06$ \\
\hline 2003 & 3411 & 67943 & 750 & 2250 & 65693 & 1. $34 \mathrm{E}+\mathrm{C}$ & $4.03 E+06$ \\
\hline 2004 & 3623 & 71566 & 750 & 3000 & 68 & $1.34 \mathrm{E}+06$ & $5.37 E+06$ \\
\hline 2005 & 3888 & 75454 & 750 & 3750 & 71 & $1.34 E+06$ & $6.71 E+06$ \\
\hline 2006 & 4132 & 79586 & 1500 & 5250 & 74 & 2.68 & $9.39 E+06$ \\
\hline 2007 & 4429 & 84015 & 1500 & 67 & 77 & $2.87 E+05$ & $1.23 E+07$ \\
\hline 2008 & 5176 & 89191 & 1500 & 8250 & 80 & $2.87 E+06$ & $1.51 E+07$ \\
\hline 2009 & 4391 & 93. & 1500 & & 83 & $2.87 \mathrm{E}+06$ & $1.80 E+07$ \\
\hline 2010 & 4497 & 98 & 1500 & & 86 & 2.87 & 2.0 \\
\hline 2011 & 4639 & 102 & 2250 & 13 & 89 & 4. $30 E+06$ & $2.52 E+07$ \\
\hline 2012 & 4625 & 107343 & 2250 & & & +06 & 2.9 \\
\hline 2013 & 4773 & 112 & 2250 & is & 94 & $4.30 E+06$ & 3.3 \\
\hline 2014 & 4948 & 1170 & 2250 & 20250 & 96 & $4.30 E+06$ & 3.8 \\
\hline 2015 & 5086 & 122150 & 2250 & & 99 & $4.30 E+06$ & 4. $23 E+07$ \\
\hline 2016 & 4964 & 127114 & 2250 & 24750 & 102364 & $4.30 E+06$ & $4.66 \bar{E}+07$ \\
\hline 2017 & 5272 & 132386 & 2250 & 27000 & 105386 & $4.03 E+06$ & $5.07 E+07$ \\
\hline 2018 & 5215 & 137601 & 2250 & 29250 & 108351 & $4.03 \bar{E}+06$ & $5.47 E+07$ \\
\hline 2019 & 5024 & 142625 & 2250 & 31500 & 111125 & $4.03 E+06$ & $5.87 \mathrm{E}+07$ \\
\hline 2020 & 5194 & 147 & 2250 & 33 & & $4.03 E+06$ & $6.27 E+07$ \\
\hline
\end{tabular}




\begin{tabular}{|c|c|c|c|c|c|c|c|}
\hline \multirow{2}{*}{$\begin{array}{l}\text { END } \\
\text { OF } \\
\text { YEAR }\end{array}$} & \multicolumn{2}{|c|}{$\begin{array}{c}\text { FUEL SUPPLIED } \\
\text { (MTIHM) }\end{array}$} & \multicolumn{2}{|c|}{ FUEL PROCESSED } & \multirow{2}{*}{$\begin{array}{c}\text { NET } \\
\text { FUEL } \\
\text { (MTIHM) }\end{array}$} & \multirow{2}{*}{$\begin{array}{l}\text { YEARLY KR85 } \\
\text { DISCHARGED } \\
\text { (CI) }\end{array}$} & \multirow{2}{*}{$\begin{array}{l}\text { ACCUM RR } \\
\text { DISCHARGED } \\
\text { (CI) }\end{array}$} \\
\hline & ANNUAL & ACCUM & ANNUAL & ACCUM & & & \\
\hline 2021 & 0 & 147819 & 2250 & 36000 & 111819 & $3.77 E+06$ & $6.65 E+07$ \\
\hline 2022 & 0 & 147819 & 2250 & 38250 & 109569 & $E+06$ & $03 E+07$ \\
\hline 2023 & 0 & 147819 & 2250 & 40500 & 107319 & $3.77 E+06$ & $7.41 E+07$ \\
\hline 2024 & 0 & 147819 & 2250 & 42750 & 105069 & $3.77 E+06$ & $7.78 E+07$ \\
\hline 2025 & 0 & 147819 & 2250 & 45000 & 102819 & $3.53 E+06$ & $8.14 E+07$ \\
\hline 2026 & 0 & 147819 & 2250 & 47250 & 100569 & $3.53 E+06$ & $8.49 E+07$ \\
\hline 2027 & 0 & 147819 & 2250 & 49500 & 98319 & $3.53 E+06$ & $8.84 \mathrm{E}+07$ \\
\hline 2028 & 0 & 147819 & 2250 & 51750 & 96069 & $3.53 E+06$ & $9.20 E+07$ \\
\hline 2029 & 0 & 147819 & 2250 & 54000 & 93819 & $3.31 E+06$ & $9.53 E+07$ \\
\hline 2030 & 0 & 147819 & 2250 & 56250 & 91569 & $3.31 E+06$ & $9.86 \mathrm{E}+07$ \\
\hline 2031 & 0 & 147819 & 2250 & 58500 & 89319 & $3.31 E+06$ & $1.02 E+08$ \\
\hline 2032 & 0 & 147819 & 2250 & 60750 & 87069 & $3.10 E+06$ & $1.05 E+08$ \\
\hline 2033 & 0 & 147819 & 2250 & 63000 & 84819 & 3. $10 E+06$ & $1.08 E+08$ \\
\hline 2034 & 0 & 147819 & 2250 & 65250 & 82569 & $3.10 E+06$ & $1.11 \mathrm{E}+08$ \\
\hline 2035 & 0 & 147819 & 2250 & 67500 & 80319 & $2.90 E+06$ & $1.14 E+08$ \\
\hline 2036 & 0 & 147819 & 2250 & 69750 & 78069 & $2.90 E+06$ & $1.17 E+08$ \\
\hline 2037 & 0 & 147819 & 2250 & 72000 & 75819 & 2. $90 E+06$ & $1.20 E+08$ \\
\hline 2038 & 0 & 147819 & 2250 & 74250 & 73569 & $2.72 E+06$ & 1. $23 E+08$ \\
\hline 2039 & 0 & 147819 & 2250 & 76500 & 71319 & $2.72 E+06$ & $1.25 \mathrm{E}+08$ \\
\hline 2040 & 0 & 147819 & 2250 & 78750 & 69069 & $2.54 E+06$ & $1.28 E+08$ \\
\hline 2041 & 0 & 147819 & 2250 & 81000 & 66819 & $2.54 E+06$ & $1.30 E+08$ \\
\hline 2042 & 0 & 147819 & 2250 & 83250 & 64569 & $2.38 E+06$ & $1.33 E+08$ \\
\hline 2043 & 0 & 147819 & 2250 & 85500 & 62319 & $2.38 E+06$ & $1.35 E+08$ \\
\hline 2044 & 0 & 147819 & 2250 & 87750 & 60069 & $2.23 E+06$ & $1.37 E+08$ \\
\hline 2045 & 0 & 147819 & 2250 & 90000 & 57819 & 2. $23 E+06$ & 1. $40 E+08$ \\
\hline 2046 & 0 & 147819 & 2250 & 92250 & 55569 & $2.09 E+06$ & $1.42 E+08$ \\
\hline 2047 & 0 & 147819 & 2250 & 94500 & 53 & $2.09 E+06$ & $1.44 E+08$ \\
\hline 2048 & 0 & 147819 & 2250 & 96750 & & $1.96 \mathrm{E}+06$ & $1.46 E+08$ \\
\hline 2049 & 0 & 147819 & 2250 & 99000 & 488 & $1.96 E+06$ & $1.48 E+08$ \\
\hline 2050 & 0 & 147819 & 2250 & 101250 & 465 & $1.83 E+06$ & $1.50 E+08$ \\
\hline 2051 & 0 & 147819 & 2250 & 103500 & 443 & $1.83 E+06$ & $1.51 \mathrm{E}+08$ \\
\hline 2052 & 0 & 147819 & 2250 & 105750 & 420 & $1.72 E+06$ & 1. $53 E+08$ \\
\hline 2053 & 0 & 147819 & 2250 & 108000 & 398 & $1.72 E+06$ & $1.55 E+08$ \\
\hline 205 & 0 & 147819 & 2250 & 110250 & 37 & $1.61 E+06$ & 1. $56 E+08$ \\
\hline 205 & 0 & 147819 & 2250 & 112500 & & 1.61 & $1.58 \mathrm{E}+08$ \\
\hline & 0 & 147819 & 2250 & 114750 & 33 & 1.51 & $1.60 E+08$ \\
\hline 205 & 0 & 147819 & 2250 & 117 & & 1.4 & $1.61 E+08$ \\
\hline & 0 & 147819 & 2250 & 119 & & $1.41 E+06$ & $1.62 E+08$ \\
\hline 205 & 0 & 147819 & 2250 & 121500 & 26 & 1. $32 E+06$ & $1.64 E+08$ \\
\hline 2060 & 0 & 147819 & 2250 & 123750 & 24 & 1. $32 E+06$ & $1.65 E+08$ \\
\hline 2061 & 0 & 147819 & 2250 & 126000 & & 1.2 & $1.66 E+08$ \\
\hline 2062 & 0 & 147819 & 2250 & 128250 & & $1.24 E+06$ & $1.67 E+08$ \\
\hline 2063 & 0 & 147819 & 2250 & 130500 & & & +08 \\
\hline 2064 & 0 & 147819 & 2250 & 132750 & & $E+06$ & $70 E+08$ \\
\hline 2065 & 0 & 147819 & 2250 & 135000 & & $E+0$ & $E+08$ \\
\hline 2066 & 0 & 147819 & 2250 & 137250 & 10 & I. $02 E+06$ & $2 E+08$ \\
\hline 2067 & 0 & 147819 & 2250 & 139500 & & $2 E+0$ & $3 E+08$ \\
\hline 2068 & 0 & 1478 & 2250 & 141750 & & $9.52 \mathrm{E}+0$ & $1.74 \mathrm{E}+08$ \\
\hline 2069 & 0 & 147819 & 2250 & 144000 & & $9.52 E+05$ & $1.75 E+08$ \\
\hline 207 & 0 & 1478 & 2250 & 146250 & & $8.92 E+05$ & $1.76 E+08$ \\
\hline
\end{tabular}


Three reprocessing scenarios were generated to examine how long the U.S. would have to maintain a viable reprocessing industry to separate the backlog of spent fuel. Scenario (case) A consists of three $750 \mathrm{tHM} / \mathrm{yr}$ FRPs coming on 1 ine five years apart beginning with the first one in 2001. Case $B$ projects the impacts upon the stored fuel backlog with two $1500 \mathrm{tHM} / \mathrm{yr}$ FRPs coming on 1 ine in 2001 and 2006, respectively. The third case (C) extends case $B$ to a third 1500 tHM plant due in 2011.

The potential impacts upon the volume of stored spent fuel attributed to these scenarios is shown in tabular form in Tables A.1, A.2, and A.3 for cases $A, B$ and $C$, respectively, and summarized here and in Figure A.l.

Under the assumption that no additional spent fuel is generated after the year 2020, the backlog would be reprocessed under case $A$ by the year 2072; case B, by the year 2053, and case C, by the year 2039. Case C (three $1500 \mathrm{tHM} / \mathrm{yr}$ FRPs) would complete the reprocessing of backlogged fuel 33 years sooner than case $A$ and 14 years sooner than case $B$. 
TABLE A.2. Reprocessing Scenario B

END FUEL SUPPLIED FUEL PROCESSED OF (MTIHM)

YEAR ANNUAL ACCUM

\begin{tabular}{|c|c|c|c|c|}
\hline 1971 & 124 & 124 & 0 & \\
\hline 1972 & 291 & 415 & 0 & \\
\hline 1973 & 165 & 580 & 0 & \\
\hline 1974 & 447 & 1027 & 0 & \\
\hline 1975 & 563 & 1590 & 0 & \\
\hline 1976 & 682 & 2272 & 0 & \\
\hline 1977 & 860 & 3132 & 0 & \\
\hline 1978 & 1150 & 4282 & 0 & \\
\hline 1979 & 1204 & 5486 & 0 & \\
\hline 1980 & 1149 & 6635 & 0 & \\
\hline 1981 & 1265 & 7900 & 0 & \\
\hline 1982 & 1089 & 8989 & 0 & \\
\hline 1983 & 1300 & 10289 & 0 & \\
\hline 1984 & 1618 & 11907 & 0 & \\
\hline 1985 & 1905 & 13812 & 0 & \\
\hline 1986 & 2207 & 16019 & 0 & \\
\hline 1987 & 2493 & 18512 & 0 & \\
\hline 1988 & 2752 & 21264 & 0 & \\
\hline 1989 & 2572 & 23836 & 0 & \\
\hline 1990 & 3238 & 27074 & 0 & \\
\hline 1991 & 2931 & 30005 & 0 & \\
\hline 1992 & 2886 & 32891 & 0 & \\
\hline 1993 & 3123 & 36014 & 0 & \\
\hline 1994 & 2993 & 39007 & 0 & \\
\hline 1995 & 2995 & 42002 & 0 & \\
\hline 1996 & 3208 & 45210 & 0 & \\
\hline 1997 & 3010 & 48220 & 0 & \\
\hline 1998 & 3090 & 51310 & 0 & \\
\hline 1999 & 3467 & 54777 & 0 & \\
\hline 2000 & 3110 & 57887 & 0 & \\
\hline 2001 & 3027 & 60914 & 1500 & 15 \\
\hline 2002 & 3618 & 64532 & 1500 & 30 \\
\hline 2003 & 3411 & 67943 & 1500 & \\
\hline 2004 & 3623 & 71566 & 1500 & \\
\hline & & & 1500 & \\
\hline 2006 & 4132 & 79586 & 3000 & \\
\hline & & & 3000 & \\
\hline 2008 & 5176 & 89191 & 3000 & \\
\hline 2009 & & 93582 & 3000 & \\
\hline 2010 & 4497 & 98079 & 3000 & \\
\hline 2011 & 4639 & 102718 & 3000 & \\
\hline 2012 & 4625 & 107343 & 3000 & \\
\hline 2013 & 47 & 112116 & 3000 & \\
\hline 2014 & 4948 & 117064 & 3000 & \\
\hline 201 & 5086 & 122150 & 3000 & \\
\hline 2016 & 4964 & 127114 & 3000 & \\
\hline & & 132386 & 3000 & \\
\hline & 5215 & 137601 & 3000 & \\
\hline & & 142625 & 3000 & \\
\hline 20 & 5194 & 147819 & 3000 & \\
\hline
\end{tabular}
(MTIHM)

ANNUAL ACCUM
NET YEARLY RR85 ACCUM. RR85

FUEL

(MTIHM)

DISCHARGED

(CI)

DISCHARGED

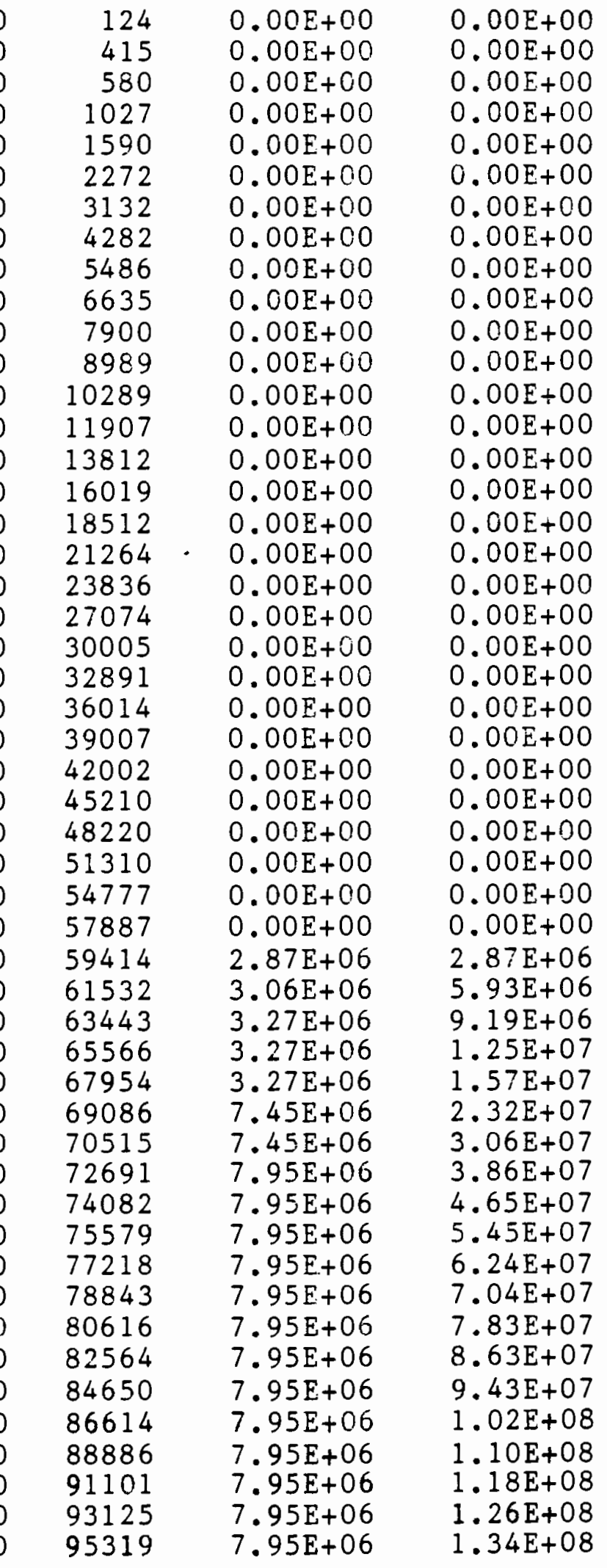




\begin{tabular}{|c|c|c|c|c|c|c|c|}
\hline $\begin{array}{l}\text { END } \\
\text { OF } \\
\text { YEAR }\end{array}$ & \multicolumn{2}{|c|}{$\begin{array}{c}\text { FUEL SUPPLIED } \\
\text { (MTIHM) }\end{array}$} & $\begin{array}{l}\text { FUEL PI } \\
(\mathrm{MT} \\
\text { ANNUAL }\end{array}$ & $\begin{array}{l}\text { OCESSED } \\
\text { HM ) } \\
\text { ACCUM }\end{array}$ & $\begin{array}{c}\text { NET } \\
\text { FUEL } \\
\text { (MTIHM) }\end{array}$ & $\begin{array}{c}\text { YEARLY KR85 } \\
\text { DISCHARGED } \\
\text { (CI) }\end{array}$ & $\begin{array}{c}\text { ACCUM RR85 } \\
\text { DISCHARGED } \\
\text { (CI) }\end{array}$ \\
\hline 2021 & 0 & 147819 & 3000 & 55500 & 92319 & $7.95 E+06$ & $1.42 E+08$ \\
\hline 2022 & 0 & 147819 & 3000 & 58500 & 89319 & $7.95 E+06$ & $1.50 \mathrm{E}+08$ \\
\hline 2023 & 0 & 147819 & 3000 & 61500 & 86319 & $7.95 E+06$ & $1.58 E+08$ \\
\hline 2024 & 0 & 147819 & 3000 & 64500 & 83319 & $7.45 E+06$ & $1.65 E+08$ \\
\hline 2025 & 0 & 147819 & 3000 & 67500 & 80319 & $7.45 E+06$ & $1.73 \mathrm{E}+08$ \\
\hline 2026 & 0 & 147819 & 3000 & 70500 & 77319 & $7.45 E+06$ & $1.80 E+08$ \\
\hline 2027 & 0 & 147819 & 3000 & 73500 & 74319 & $7.45 E+06$ & $1.88 E+08$ \\
\hline 2028 & 0 & 147819 & 3000 & 76500 & 71319 & $7.45 E+06$ & $1.95 E+08$ \\
\hline 2029 & 0 & 147819 & 3000 & 79500 & 68319 & $6.98 E+06$ & $2.02 E+08$ \\
\hline 2030 & 0 & 147819 & 3000 & 82500 & 65319 & $6.98 E+06$ & $2.09 E+08$ \\
\hline 2031 & 0 & 147819 & 3000 & 85500 & 62319 & $6.98 E+06$ & $2.16 E+08$ \\
\hline 2032 & 0 & 147819 & 3000 & 88500 & 59319 & $6.53 E+06$ & $2.23 E+08$ \\
\hline 2033 & 0 & 147819 & 3000 & 91500 & 56319 & $6.53 E+06$ & $2.29 E+08$ \\
\hline 2034 & 0 & 147819 & 3000 & 94500 & 53319 & $6.53 E+06$ & $2.36 E+08$ \\
\hline 2035 & 0 & 147819 & 3000 & 97500 & 50319 & $6.12 E+06$ & $2.42 E+08$ \\
\hline 2036 & 0 & 147819 & 3000 & 100500 & 47319 & $6.12 E+06$ & $2.48 E+08$ \\
\hline 2037 & 0 & 147819 & 3000 & 103500 & 44319 & $6.12 E+06$ & $2.54 E+08$ \\
\hline 2038 & 0 & 147819 & 3000 & 106500 & 41319 & $5.73 E+06$ & $2.60 E+C 8$ \\
\hline 2039 & 0 & 147819 & 3000 & 109500 & 38319 & $5.73 E+06$ & $2.65 E+08$ \\
\hline 2040 & 0 & 147819 & 3000 & 112500 & 35319 & $5.73 E+06$ & $2.71 E+08$ \\
\hline 2041 & 0 & 147819 & 3000 & 115500 & 32319 & $5.37 E+06$ & $2.77 E+08$ \\
\hline 2042 & 0 & 147819 & 3000 & 118500 & 29319 & $5.37 E+06$ & $2.82 E+08$ \\
\hline 2043 & 0 & 147819 & 3000 & 121500 & 26319 & $5.03 E+06$ & $2.87 E+08$ \\
\hline 2044 & 0 & 147819 & 3000 & 124500 & 23319 & $5.03 E+06$ & $2.92 E+08$ \\
\hline 2045 & 0 & 147819 & 3000 & 127500 & 20319 & $5.03 E+06$ & $2.97 E+08$ \\
\hline 2046 & 0 & 147819 & 3000 & 130500 & 17319 & $4.71 E+06$ & $3.02 E+0.8$ \\
\hline 2047 & 0 & 147819 & 3000 & 133500 & 14319 & $4.71 E+06$ & $3.06 E+08$ \\
\hline 2048 & 0 & 147819 & 3000 & 136500 & 11319 & $4.41 E+06$ & $3.11 E+08$ \\
\hline 2049 & 0 & 147819 & 3000 & 139500 & & $4.41 E+06$ & $3.15 E+08$ \\
\hline 2050 & 0 & 147819 & 3000 & 142500 & & $4.13 E+06$ & 3. $19 E+08$ \\
\hline 2051 & 0 & 147819 & 3000 & 145500 & 2319 & $4.13 E+06$ & $3.24 E+08$ \\
\hline 2052 & 0 & 147819 & 3000 & 148500 & -681 & $4.13 E+06$ & $3.28 E+08$ \\
\hline
\end{tabular}


TABLE A.3. Reprocessing Scenario C

\begin{tabular}{|c|c|c|c|c|c|c|c|}
\hline $\begin{array}{l}\text { END } \\
\text { OF }\end{array}$ & $\begin{array}{r}\text { FUEL S } \\
(\mathrm{MT}\end{array}$ & $\begin{array}{l}\text { PPLIED } \\
\text { HM) }\end{array}$ & $\begin{array}{r}\text { FUEL } P \\
(\mathrm{MT}\end{array}$ & $\begin{array}{l}\text { CESSED } \\
\text { (M) }\end{array}$ & $\begin{array}{l}\text { NET } \\
\text { FUEL }\end{array}$ & $\begin{array}{l}\text { YEARLY KR85 } \\
\text { DISCHARGED }\end{array}$ & $\begin{array}{l}\text { ACCUM KR } \\
\text { DISCHARGED }\end{array}$ \\
\hline YEAR & ANNUAL & ACCUM & ANNUAL & ACCUM & (MTIHM) & $(C I)$ & (CI) \\
\hline 1971 & 124 & 124 & 0 & 0 & 124 & $0.00 E+00$ & $0.00 E+00$ \\
\hline 1972 & 291 & 415 & 0 & 0 & 415 & $0.00 E+00$ & $0.00 \mathrm{E}+00$ \\
\hline 1973 & 165 & 580 & 0 & 0 & 580 & $0.00 E+00$ & $0.00 E+00$ \\
\hline 1974 & 447 & 1027 & 0 & 0 & 1027 & $0.00 E \div 00$ & $0.00 E+00$ \\
\hline 1975 & 563 & 1590 & 0 & 0 & 1590 & $0.00 E+00$ & $0.00 E+00$ \\
\hline 1976 & 682 & 2272 & 0 & 0 & 2272 & $0.00 E+00$ & $0.00 E+00$ \\
\hline 1977 & 860 & 3132 & 0 & 0 & 3132 & $0.00 \mathrm{E}+00$ & $0.00 E+00$ \\
\hline 1978 & 1150 & 4282 & 0 & 0 & 4282 & $0.00 E+00$ & $0.00 E+00$ \\
\hline 1979 & 1204 & 5486 & 0 & 0 & 5486 & $0.00 E+00$ & $0.00 E+00$ \\
\hline 1980 & 1149 & 6635 & 0 & 0 & 6635 & $0.00 E+00$ & $0.00 E+00$ \\
\hline 1981 & 1265 & 7900 & 0 & 0 & 7900 & $0.00 E+00$ & $0.00 E+00$ \\
\hline 1982 & 1089 & 8989 & 0 & 0 & 8989 & $0.00 E+00$ & $0.00 E+00$ \\
\hline 1983 & 1300 & 10289 & 0 & 0 & 10289 & $0.00 E+00$ & $0.00 E+00$ \\
\hline 1984 & 1618 & 11907 & 0 & 0 & 11907 & $0.00 E+00$ & $0.00 E+00$ \\
\hline 1985 & 1905 & 13812 & 0 & 0 & 13812 & $0.00 E+00$ & $0.00 E+00$ \\
\hline 1986 & 2207 & 16019 & 0 & 0 & 16019 & $0.00 E+00$ & $0.00 E+00$ \\
\hline 1987 & 2493 & 18512 & 0 & 0 & 18512 & $0.00 E+00$ & $0.00 E+00$ \\
\hline 1988 & 2752 & 21264 & 0 & 0 & 21264 & $0.00 E+00$ & $0.00 E+00$ \\
\hline 1989 & 2572 & $238: 5$ & 0 & 0 & 23836 & $0.00 E+00$ & $0.00 E+00$ \\
\hline 1990 & 3238 & 27074 & 0 & 0 & 27074 & $0.00 E+00$ & $0.00 E+00$ \\
\hline 1991 & 2931 & 30005 & 0 & 0 & 30005 & $0.00 E+00$ & $0.00 E+00$ \\
\hline 1992 & 2886 & 32891 & 0 & 0 & 32891 & $0.00 E+00$ & $0.00 E+00$ \\
\hline 1993 & 3123 & 36014 & 0 & 0 & 36014 & $0.00 E+00$ & $0.00 E+00$ \\
\hline 1994 & 2993 & 39007 & 0 & 0 & 39007 & $0.00 E+00$ & $0.00 E+00$ \\
\hline 1995 & 2995 & 42002 & 0 & 0 & 42002 & $0.00 E+00$ & $0.00 E+00$ \\
\hline 1996 & 3208 & 45210 & 0 & 0 & 45210 & $0.00 E+00$ & $0.00 E+00$ \\
\hline 1997 & 3010 & 48220 & 0 & 0 & 48220 & $0.00 E+00$ & $0.00 E+00$ \\
\hline 1998 & 3090 & 51310 & 0 & 0 & 51310 & $0.00 E+00$ & $0.00 E+00$ \\
\hline 1999 & 3467 & 54777 & 0 & 0 & 54777 & $0.00 E+00$ & $0.00 E+00$ \\
\hline 2000 & 3110 & 57887 & 0 & 0 & 57887 & $0.00 E+00$ & $0.00 E+00$ \\
\hline 2001 & 3027 & 60914 & 1500 & 1500 & 59414 & $2.87 E+06$ & $2.87 E+06$ \\
\hline 2002 & 3618 & 64532 & 1500 & 3000 & 61532 & $3.06 E+06$ & $5.93 E+06$ \\
\hline 2003 & 3411 & 67943 & 1500 & 4500 & 63443 & $3.27 E+06$ & $9.19 E+06$ \\
\hline 2004 & 3623 & 71566 & 1500 & 6000 & 65566 & $3.27 E+06$ & $1.25 \mathrm{E}+07$ \\
\hline 2005 & 3888 & 75454 & 1500 & 7500 & 67954 & $3.27 E+06$ & $1.57 \mathrm{E}+07$ \\
\hline 2006 & 4132 & 79586 & 3000 & 10500 & 69086 & $7.45 \mathrm{E}+06$ & $2.32 \mathrm{E}+07$ \\
\hline 2007 & 4429 & 840 & 3000 & 13 & 70515 & $7.45 E+06$ & $3.06 E+07$ \\
\hline 2008 & 5176 & 89191 & 3000 & 16 & 72691 & $7.95 E+06$ & $3.86 \mathrm{E}+07$ \\
\hline 2009 & 4391 & 93582 & 3000 & 19 & 74082 & $7.95 \mathrm{E}+06$ & $4.65 E+07$ \\
\hline 2010 & 4497 & 98079 & 3000 & 22500 & 75579 & 7.9 & +07 \\
\hline 2011 & 4639 & 102718 & 4500 & 27000 & 75718 & $1.19 \mathrm{E}+07$ & $6.64 E+07$ \\
\hline 2012 & 4625 & 107343 & 4500 & 31500 & 75843 & 1.27 & 7.92 \\
\hline 2013 & 4773 & 112116 & 4500 & 36000 & 76116 & $1.27 \mathrm{E}+07$ & $9.19 \mathrm{E}+07$ \\
\hline 2014 & 4948 & 117064 & 4500 & 40500 & 76564 & $1.36 \mathrm{E}+07$ & $1.05 E+08$ \\
\hline 2015 & 5086 & 122150 & 4500 & 45000 & & $1.36 E+07$ & $1.19 E+08$ \\
\hline 2016 & 4964 & 127114 & 4500 & 49500 & 77614 & $1.45 E+07$ & 1.34 \\
\hline & 5272 & 132386 & 4500 & 54000 & 78386 & $1.45 \mathrm{E}+07$ & +08 \\
\hline & 5215 & 137601 & 4500 & 58 & & $1.55 E+07$ & \\
\hline & 5024 & & 4500 & & & $1.5:$ & \\
\hline 2020 & 5194 & & 4500 & & 80319 & $1.55 \mathrm{E}+07$ & $1.95 E+08$ \\
\hline
\end{tabular}




\begin{tabular}{|c|c|c|c|c|c|c|c|}
\hline \multirow{2}{*}{$\begin{array}{l}\text { END } \\
\text { OF } \\
\text { YEAR }\end{array}$} & \multicolumn{2}{|c|}{$\begin{array}{l}\text { FUEL SUPPLIED } \\
\text { (MTIHM) }\end{array}$} & \multicolumn{2}{|c|}{$\begin{array}{c}\text { FUEL PROCESSED } \\
\text { (MTIHM })\end{array}$} & \multirow{2}{*}{$\begin{array}{c}\text { NET } \\
\text { FUEL } \\
\text { (MTIHM) }\end{array}$} & \multirow{2}{*}{$\begin{array}{l}\text { YEARLY KR85 } \\
\text { DISCHARGED } \\
\text { (CI) }\end{array}$} & \multirow{2}{*}{$\begin{array}{l}\text { ACCUM R R85 } \\
\text { DISCHARGED } \\
\text { (CI) }\end{array}$} \\
\hline & ANNUAL & ACCUM & ANNUAL & ACCUM & & & \\
\hline 2021 & 0 & 147819 & 4500 & 72000 & 75819 & $1.66 E+07$ & $2.11 E+08$ \\
\hline 2 & 0 & 147819 & 4500 & 76500 & 71319 & $1.66 E+07$ & $2.28 E+08$ \\
\hline 202 & 0 & 147819 & 4500 & 81000 & 66819 & $66 E+07$ & $2.44 E+08$ \\
\hline & 0 & 147819 & 4500 & 85500 & 62319 & $1.66 E+07$ & $2.61 E+08$ \\
\hline 2025 & 0 & 147819 & 4500 & 90000 & 57819 & $1.66 \mathrm{E}+07$ & $2.77 E+08$ \\
\hline & 0 & 147819 & 4500 & 94500 & 53319 & $1.66 E+07$ & $2.94 E+08$ \\
\hline & 0 & 147819 & 4500 & 99000 & 48819 & $1.66 \mathrm{E}+07$ & \\
\hline & 0 & 147819 & 4500 & 103500 & 44319 & $1.66 E+07$ & $3.27 E+08$ \\
\hline & 0 & 147819 & 4500 & 108000 & 39819 & $1.66 \mathrm{E}+07$ & $3.44 E+08$ \\
\hline & 0 & 147819 & 4500 & 112500 & 35319 & $1.66 \mathrm{E}+07$ & $3.60 E+08$ \\
\hline & 0 & 147819 & 4500 & 117000 & 30819 & $1.55 \mathrm{E}+07$ & $3.76 E+08$ \\
\hline & 0 & 147819 & 4500 & 121500 & 26319 & $1.55 \mathrm{E}+07$ & $3.91 E+08$ \\
\hline 20 & 0 & 147819 & 4500 & 126000 & 21819 & $1.55 E+07$ & $4.07 E+08$ \\
\hline 20 & 0 & 147819 & 4500 & 130500 & 17319 & $1.55 E+07$ & 4. $22 E+08$ \\
\hline 20 & 0 & 147819 & 4500 & 135000 & 12819 & $1.55 E+07$ & 4. $38 E+08$ \\
\hline & 0 & 1478 & 4500 & 139500 & 8319 & +07 & $4.53 E+08$ \\
\hline & 0 & 1478 & 4500 & 144000 & 3819 & +07 & 4.6 \\
\hline & 0 & 147819 & 4500 & 148500 & -681 & +07 & $4.84 E+08$ \\
\hline
\end{tabular}




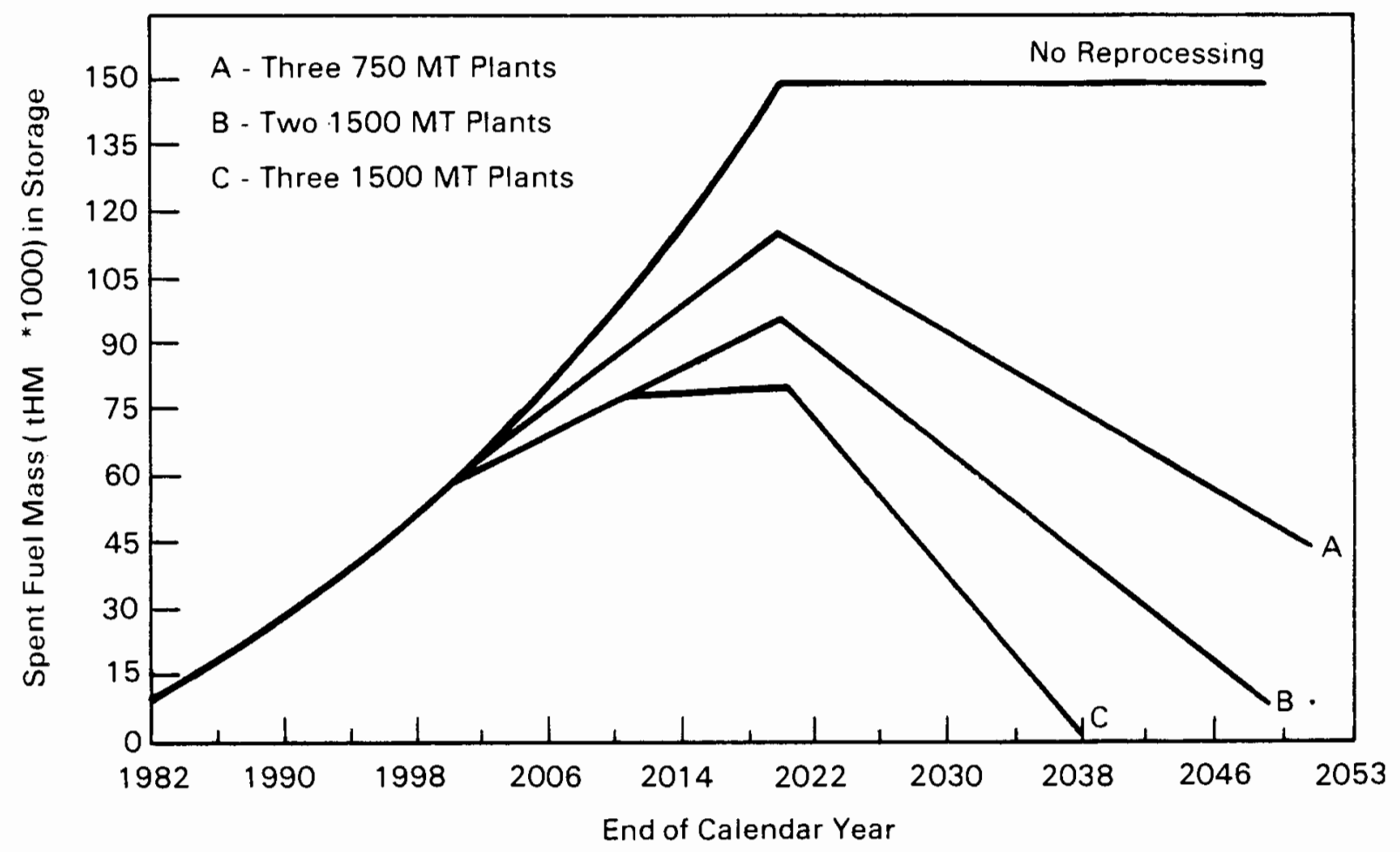

FIGURE A.1. Spent Fuel in Storage with Three Reprocessing Scenarios

A. 9 


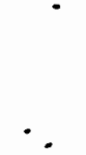


APPENDIX B

METHODS FOR CALCULATING OCCUPATIONAL DOSES FROM KRYPTON-85 EXPOSURE 


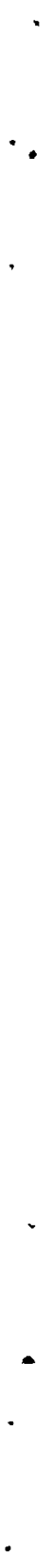


APPENDIX B

METHQDS FOR CALCULATING OCCUPATIONAL DOSES FROM $85^{\mathrm{Kr}}$ EXPOSURE

\section{B.I ISOSHLD-II}

ISOSHLD-II [an extension of ISOSHLD (Engle et a 1. 1966) both developed at Pacific Northwest Laboratory] is a computer code used to perform betaand gamma-ray shielding calculations for isotopic sources in a variety of source and shield configurations. The energy distribution of bremsstrahlung produced by the slowing down and stopping of beta particles is assumed to be produced only in the source region. Attenuation calculations are performed by point kernel integration; for most geometries by Simpson's rule numerical integration. Buildup factors are calculated by the code based on the number of mean-free paths of material between the source and dose points, the effective atomic number of a particular shield region, and the point isotropic buildup data available as Taylor coefficients. Other data needed to solve most isotope shielding of practical interest are 1 inked to ISOSHLD in various 1 ibraries. For most problems the user need on ly supply:

- The geometry and material composition of the source

- The geometry and materials of the shields.

\section{B.2 CYLIN}

CYLIN is a point kernel shielding code developed at Pacific Northwest Laboratory as a modification of the shielding code PERCS (Reece et al. 1984). The modified code computes doses from gamma emitting radioisotopes within a cylindrical volume, whereas PERCS computes the doses from sources located on the interior surfaces of cylinders. The self-shielding of the source is also taken into account.

The evaluation of the point kernel equation for a cylindrical source is a triple integral of the form 
Dose $=\frac{1}{4 \pi T} \int_{A L O W}^{A H I G H} \int_{0}^{R} \int_{0}^{2 T T} \frac{S A *[B L D U P * E * Y I E L D * K(E) * E X P(-B S U M)] r d A L P H A d A d r}{R H O^{2}}$

where AHIGH and ALOW = the top and bottom elevation of the source

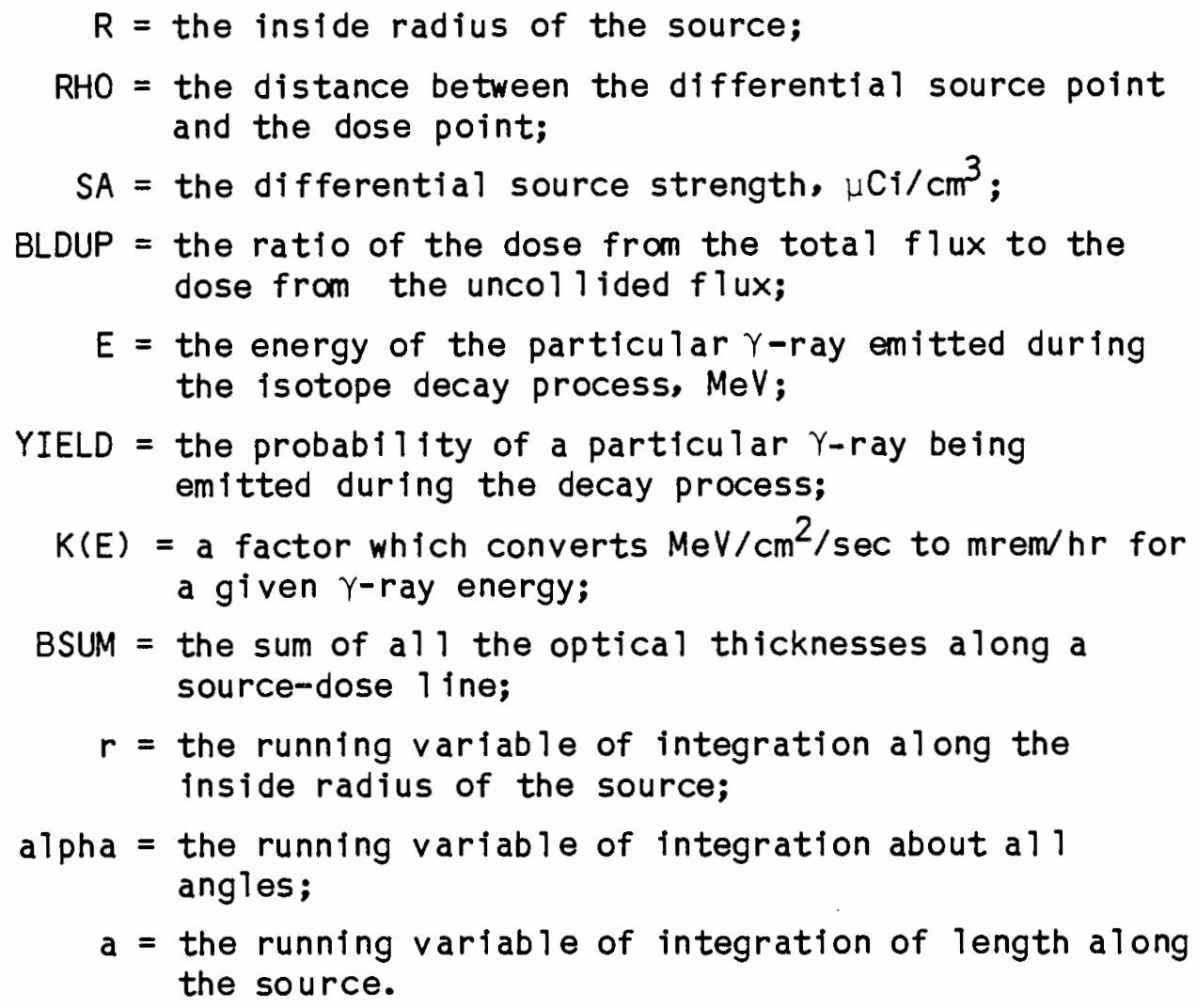

For every dose point CYLIN evaluates the contribution of each source volume by calculating al 1 the parameters such as upper and lower 1 imits of integration and inftiating the numerical integration of the point kernel. The triple integration through the angle, radius, and length of the cylindrical volume is done by spline quadrature routines or Newton-Cotes quadrature routines, depending on the location of the dose point relative to the source. As each differential source element is chosen, al 1 the cylinders and auxlliary shields are checked to determine if they 1 ie between the source element and the dose point. A tally is kept of the contribution to optical thickness and the relative location of each shield. 
After the geometric calculations are done, the concentration of each isotope in the differential volume is computed and each gamma energy and yield for that isotope is used, along with the calculated buildup factor, to evaluate the point kernel equation. The quadrature routines are then used to calculate the integral. This is done for each source volume element and the total dose is the sum of the contribution from each source. The next dose point is then prompted from the user and the calculations are repeated.

The program CYLIN calculates the dose from up to twenty cylindrical sources and cylindrical or rectangular shields in any configuration. PERCS has been tested against other current shielding codes with good results and CYLIN dose values are compared in the fol lowing table against the wel 1known point kernel shielding code ISOSHLD-II.

$$
\text { eylinder Filled with } 85 \mathrm{Kr}
$$

\begin{tabular}{|c|c|c|}
\hline Dose Points & CYLIN & ISOSHLD-II \\
\hline 4' elevation at surface & $25.65 \mathrm{mrem} / \mathrm{hr}$ & $27.17 \mathrm{mrem} / \mathrm{hr}$ \\
\hline $12^{\prime}$ elevation at surface & $25.98 \mathrm{mrem} / \mathrm{hr}$ & $27.20 \mathrm{mrem} / \mathrm{hr}$ \\
\hline $4^{\prime}$ elevation at $3^{\prime}$ away & 2.702 & $2.622 \mathrm{mrem} / \mathrm{hr}$ \\
\hline $12^{\prime}$ elevation at $3{ }^{\prime}$ away & 2.936 & $2.951 \mathrm{mrem}$ \\
\hline
\end{tabular}

cylinder: radius $=11.43 \mathrm{~cm}$; height $=731.5 \mathrm{~cm}$; filled with 10 curies ${ }^{85} \mathrm{Kr}$; wall thickness $=0.93 \mathrm{~cm}$; wall material-steel; no shielding.

Some of the principal advantages of CYLIN are as follows:

1. Completely arbitrary geometry is al lowed in cylinder location, size, and source content (both spatially and isotopically).

2. The location of the dose point is completely arbitrary, including inside a cylinder or shield. The single exception is the placement of the dose point exactly on the centerline of the cylindrical source.

3. The shielding of the distributed source by the cylinder and its contents is calculated.

4. All other cylindrical sources and shields on a 1 ine-of-sight between the differential source point and the dose point are included in the buildup calculation. 
更

.

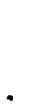

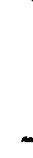
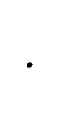
APPENDIX C

EOUATIONS FOR CALCULATING DOSES FROM ${ }^{85}$ KR EXPOSURE TO THE PUBLIC 
ง 
APPENDIX $C$

EQUATIONS FOR CALCULATING DOSES FROM $85 \mathrm{Kr}$ EXPOSURE TO THE PUBLIC

Several equations are used to characterize the segment of the population being exposed and the conditions of the ${ }^{85} \mathrm{Kr}$ release. The population segments considered are the maximally exposed individual and the regional population.

\section{C.1 MAXIMUM INDIYIDUAL DOSE}

The maximum individual dose assumes that an individual continuously resides at the point of highest ground level concentration of $85 \mathrm{Kr}$ released from the BNFP stack. Depending upon the release height, terrain and meteorology, this point is generally within a few miles of the plant. Equation 1 is the annual dose equation multiplied by 30 years to obtain a 30-year cumulative dose.

$$
\begin{aligned}
\operatorname{Dose}_{30}= & \frac{(\mathrm{Ci} / \mathrm{yr})\left(\bar{x} / 0^{\prime} \mathrm{sec} / \mathrm{m}^{3}\right)\left(10^{12} \mathrm{pCi} / \mathrm{Ci}\right)}{3.15 \times 10^{7} \mathrm{sec} / \mathrm{yr}} \\
& \left(D f \mathrm{rem} / \mathrm{yr} \mathrm{per} \mathrm{pCi} / \mathrm{m}^{3}\right)(30 \mathrm{yr})
\end{aligned}
$$

where $\mathrm{Ci} / \mathrm{yr}$ is the annual ${ }^{85} \mathrm{Kr}$ effluent;

$\bar{X} / Q^{\prime}$ is the annual average atmospheric dispersion factor, $\mathrm{sec} / \mathrm{m}^{3}$;

Df is the external dose factor, $1.9 E-8 \mathrm{rem} / \mathrm{yr}$ per $\mathrm{pCi} / \mathrm{m}^{3}$;

30 is the operational life time of the FRP.

The annual average atmospheric dispersion factors $\left(\bar{X} / Q^{\prime}\right)$ calculated for the BNFP Separations Facility main stack of $100 \mathrm{~m}$ height are presented in Table 4.2. By inspection of the data, the maximum offsite ground-level concentration $\left(\bar{X} / Q^{\prime}=1.3 \mathrm{E}-8 \mathrm{sec} / \mathrm{m}^{3}\right)$ occurs 1 to $2 \mathrm{miles}$ from the $\mathrm{plant}$ in the E direction.

The external dose factors (Df) used here are calculated as shown by Soldat et al. (1976). However, for comparison, Table C.l lists published 
IABLE_C.1. Comparison of Several External Dose Factors for $85 \mathrm{Kr}$ in the Literature (rem/yr per $\mathrm{pCi} / \mathrm{m}^{3}$ )

\begin{tabular}{|c|c|c|c|c|c|}
\hline$B-S k$ in & $\gamma$-skin & $B+y-S k$ in & $\gamma$-Testes & $y$-Total Body & Reference \\
\hline $1.4 E-6$ & $2.4 \mathrm{E}-8$ & $1.4 \mathrm{E}-6$ & $1.9 E-8$ & $1.9 E-8$ & Soldat et al. 1976 \\
\hline $1.3 \mathrm{E}-6$ & -- & -- & -- & $1.6 \mathrm{E}-8$ & NRC 1977 \\
\hline $1.5 E-6$ & --- & $1.5 \mathrm{E}-6$ & $2.9 E-8$ & $2.9 E-8$ & Schaeffer 1973 \\
\hline-- & -- & $1.5 E-6$ & -- & $1.6 E-8$ & Strenge 1981 \\
\hline $2.2 E-6$ & $1.8 \mathrm{E}-8$ & $2.2 \mathrm{E}-6$ & --- & $1.8 \mathrm{E}-8$ & Killough et al. 1976 \\
\hline
\end{tabular}

values by several workers. The assumptions used by these authors were not always the same. This is especially true of the depth at which the "skin" dose was calculated. The dose to the internal organs, including the lung, from external exposure is generally assumed to be the same as the totalbody dose. To estimate the lung dose from inhalation. Soldat et al. (1976) calculated dose factors from the ICRP initial lung model (ICRP 1959). The concentration of the noble gas in the air within the lung is assumed to be the same as that in the inspired air. The effective energies of the individual radiations are calculated using an effective radius of $10 \mathrm{~cm}$ for the Tung.

The inhalation dose factor calculated by Soldat is compared in Table C.2 with values obtained by other researchers. Caution should be used when making a critical comparison of these values. For example, Russe 11 and Galpin (1972) used a lung volume of 5.6 liters, Soldat et a 1. (1976) based their calculations on a lung volume of 4 1iters, and Whitton (1968) did not state the lung volume used for her calculations. When the variations in assumptions are factored into the calculation of the dose factors by these various researchers, there is reasonable agreement among the values.

The total dose would of course be the sum of the external component and the internal contribution. The doses from ${ }^{85} \mathrm{Kr}$ absorbed in tissue is generally smal 1 compared to the dose from direct external radiation. It is apparent that for ${ }^{85} \mathrm{Kr}$ the skin is the critical organ for individuals. For 
col lective dose calculations the generally accepted practice is to calculate total-body doses so that health effects could then be estimated if desired.

\section{C.2 50-MILE POPULATION DOSE}

The dose to the 50-mile poputation is the annual dose multiplied by 30 years (Equation 2).

$$
\begin{aligned}
& \operatorname{Dose}_{30}= \frac{(\mathrm{C} i / \mathrm{yr}) \sum\left(\bar{x} / \mathrm{O}^{\prime}\right)(\mathrm{POP}) \frac{\mathrm{sec} \cdot \mathrm{man}}{\mathrm{m}^{3}}}{3.15 \times 10^{7} \mathrm{sec} / \mathrm{yr}} \\
&\left(10^{12} \mathrm{pCi} / \mathrm{C} i\right)\left(\mathrm{Df} \frac{\mathrm{rem}}{\mathrm{yr}} \operatorname{per} \frac{\mathrm{PC} i}{\mathrm{~m}^{3}}\right)(30 \mathrm{yr})
\end{aligned}
$$

where: $\left[\left(\bar{X} / Q^{\prime}\right)(P O P)\right]$ is the integrated population times annual average atmospheric dispersion factor, $\mathrm{sec} \cdot \mathrm{man} / \mathrm{m}^{3}$.

TABLE C.2. Comparison of Inhalation.Dose Factors

\begin{tabular}{|c|c|}
\hline DCF (Lung) & Reference \\
\hline $1.7 E-8$ & Soldat et a 1. 1976 \\
\hline $5.1 E-8$ & Schaeffer 1973 \\
\hline $1.4 E-8$ & Whitton 1968 \\
\hline $2.6 E-8$ & Russe 11 and GaTpin 1972 \\
\hline $1.8 E-8$ & Snyder et a 1. 1975 \\
\hline
\end{tabular}
for ${ }^{85} \mathrm{Kr}$ and the Lung (rem/yr per $\mathrm{pCi} / \mathrm{m}^{3}$ ) 
PNL-5209

UC- 86

\section{DISTRIBUTION}

No. of

Copies

OFFSITE

2 B. J. Baxter

G. A. Technologies, Inc.

P. O. Box 81608

San Diego, CA 92138

J. 0. Blomeke

Oak Ridge National Laboratory

P. 0. Box $X$

Oak Ridge, TN 37830

\section{R. A. Brown \\ Westinghouse Idaho \\ Nuclear Co., Inc. \\ P. 0. Box 4000 \\ Idaho Falls, ID 83401}

2 W. D. Burch

Oak Ridge National Laboratory

P. O. Box $X$

Oak Ridge, TN 37830

J. D. Christian

Westinghouse Idaho

Nuclear Co., Inc.

P. 0. Box 4000

Idaho Falls, ID 83401

V. R. Deitz

Nava1 Research Laboratory

Washington, DC 20375
No. of

Copies
R. J. Jubin

Oak Ridge National Laboratory

P. O. Box X

Oak Ridge, TN 37830

J. H. Kittel OTD

Argonne National Laboratory

9700 So. Cass Avenue

Argonne, IL 60439

J. R. McBride

E. R. Johnson and Associates, Inc.

11702 Bowman Green Drive

Reston, VA 22090

T. R. Thomas

Westinghouse Idaho

Nuclear Co.., Inc.

P. O. Box 4000

Idaho Fal1s, ID 83401

R. G. Wymer

Oak Ridge National Laboratory P. 0. Box $X$

Oak Ridge, TN 37830

10 H. E. Stelling

U.S. Department of Energy GTN - NE-44

Washington, DC 20545

27 DOE Technical Information Center 
PNL-5209

UC-86

\section{ONSITE}

4 DOE Richland Operations Office

M. W. Shupe

J. L. Rhoades

J. D. White

H. E. Ransom

3 Rockwell Hanford Operations

R. M. Orme

R. C. Roal

W. W. Schulz

2 Westinghouse Hanford Company

A. G. Blasewitz

R. E. Lerch

45 Pacific Northwest Laboratory

L. W. Brackenbush (5)

P. E. Bramson

F. P. Brauer

J. B. Brown

T. C. Chikalla

E. S. Gilbert

W. A. Glass

R. W. Goles

K. A. Haw ley

L. T. Lakey

R. C. Lijkala

E. D. MCClanahan

J. L. McE Troy

P. J. Mellinger (15)

B. A. Napier

R. G. Schreckhise

D. L. Strenge

J. E. Tanner

G. L. Tingey

C. M. Unruh

Technical Library (5)

Publishing Coordination (2) 